\title{
LOOKING FOR LOST PIECES OF A PUZZLE: THE DOLLKEIM-KOVROVO CULTURE CEMETERY AT PERDOLLEN
}

\section{AGATA CHILIŃSKA-FRÜBOES ${ }^{*}$}

${ }^{1}$ Institute of Archaeology, Jagiellonian University in Kraków, Gołębia 11, 31-007 Kraków

Keywords

Dollkeim-Kovrovo culture, funeral rite, Carl Engel, Roman period, Early Migration period

\begin{abstract}
The article is devoted to the archaeological discoveries in the former village of Perdollen. A flat cemetery of Dollkeim-Kovrovo culture was discovered in this locality, dating back to the Roman period, and probably also to the Early Migration period. Moreover, there was a cemetery from modern times with inhumation graves. The Dollkeim-Kovrovo culture cemetery was badly damaged by agricultural work, and the extraction of gravel and sand. Most of the artefacts discovered there come from excavations carried out by Carl Engel in the 1930s. Apart from one fibula, probably a Roman import, all the items are lost. The sources of knowledge about the state of research are almost exclusively archival materials and some daily newspapers.
\end{abstract}

\section{Introduction}

While browsing through numerous materials in the Engel archive, scattered around several research institutions (Johann Gottfried Herder-Institut für historische Ostmitteleuropaforschung - Institut der Leibniz-Gemeinschaft, Marburg [Herder-Institut] Museum für Archäologie, Schleswig [MfA], Georg-August-Universität Göttingen, Museum für Vor- und Frühgeschichte, Staatliche Museen zu Berlin, and Preußischer Kulturbesitz, Berlin [MVF]), I still came across records of archaeological research in the former Perdollen, Kr. Labiau ${ }^{1}$ fragments of excavation documentation (descriptions of objects, sketches of plans of objects and trenches, photographs taken in situ, etc), and clippings from daily newspapers published in Königsberg in the 1930s. In addition, in the MVF, I came across an open-work disc fibula from Perdollen, although it was incorrectly assigned to a different archaeological site, and

\footnotetext{
1 Today, Petino in the Polessk district. I use the prewar name of this locality in the article, while all other sites have their current names.
}

is most likely a Roman import. The enormous amount of information I found about the research at Perdollen, and the fact that it is almost completely forgotten, made me decide to describe what Engel discovered there. The cemetery at Perdollen is extremely important, as we still know little about the prehistory of the region in which it is located. Although the site was badly damaged, as will be described below, it yielded many important archaeological finds, including at least one Roman import. The study of the Perdollen material also contributes a lot to considerations about the funeral rites of Dollkeim-Kovrovo culture (Fig. 1) $)^{2}$.

\footnotetext{
2 The usual term for people inhabiting the Samland Peninsula, Natangia and Nadrovia in the Roman and the Migration period is Dollkeim-Kovrovo culture, introduced by Wojciech Nowakowski (1996). Some researchers, however, do not recognise this, and use the term Sambian-Natangian culture (see e.g. Skvortsov 2012b). These researchers do not provide clear arguments in their studies to explain their rejection of the concept of Dollkeim-Kovrovo culture.
}

\footnotetext{
* E-mail: agata.chilinska-fruboes@uj.edu.pl

DOI: http://dx.doi.org/10.15181/ab.v28i0.2288

Received 07.07.2021; Revised 07.08.2021; Accepted 21.09.2021
} 


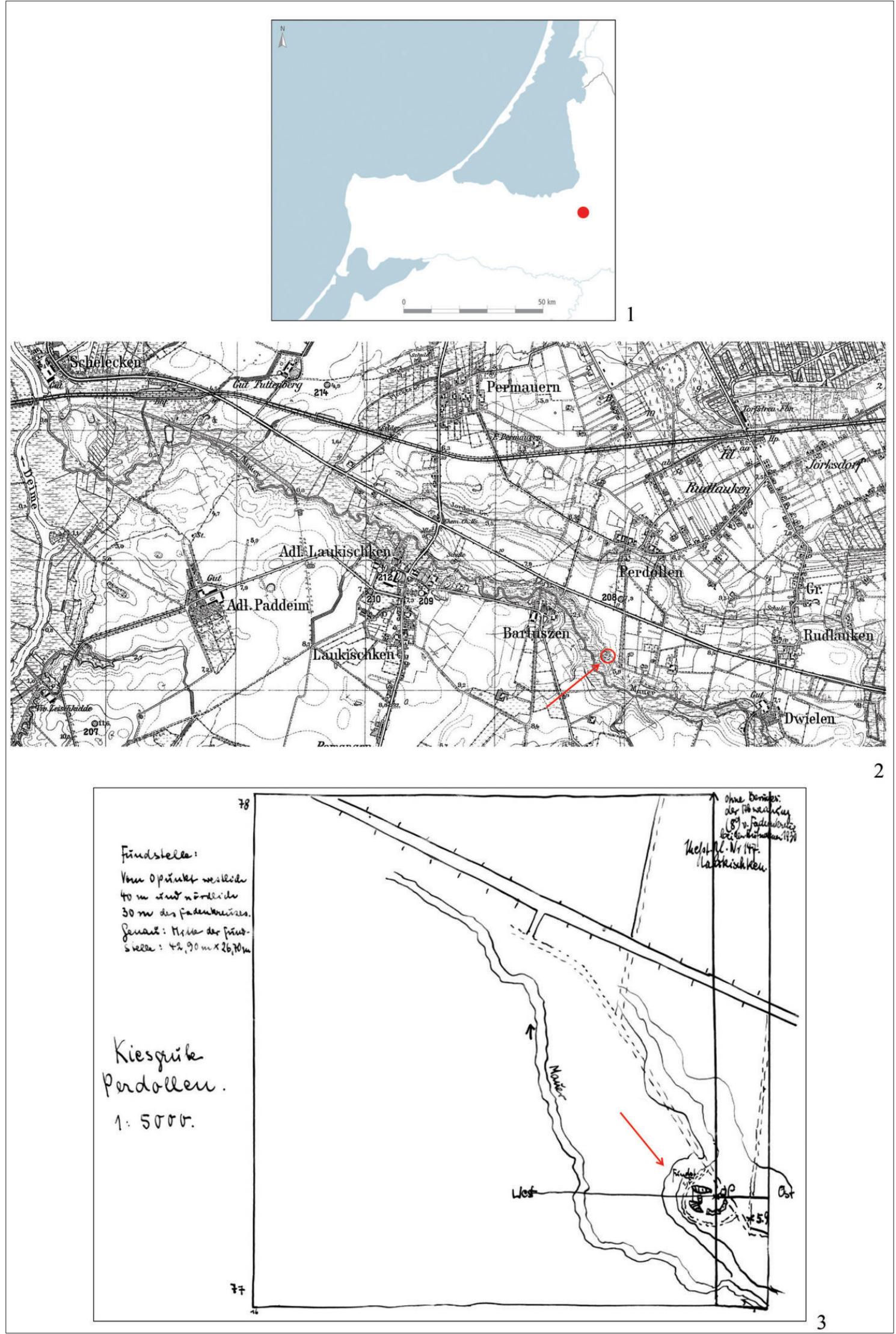

Figure 1. 1. The location of the village of Perdollen; 2-3. The location of the flat cemetery in Perdollen (1. by Chilińska-Früboes. 2. http://maps.mapywig.org/m/German maps/series/025K TK25/1193 (147) Laukischken Planblatt A 1929 uniberk C057602092.jpg, no scale. 3. SMB-PK/MVF, PM-IXd8, PM-A 1186/1). 


\section{Sources}

Published mentions of archaeological research at Perdollen are quite random, and often of a popular scientific nature. We learn from the records of Rudolf Grenz (archive, book 86) that in the Labiauer Kreisezeitung newspaper', published before the end of the Second World War, Anton Doskocil mentioned some Neolithic artefacts, items from the Roman period, and Medieval materials, found in the village of Perdollen. Wilhelm Gaerte mentions in one of his works that in the years 1925 and 1926, discoveries were made in Perdollen in a flat cemetery from the Roman period (Gaerte 1927, p. 10). In 1930, Engel published several short, popularising texts in the daily newspaper Königsberger Hartungsche Zeitung concerning two seasons of his research at Perdollen, in May and July 1930 (Engel 1930a; 1930b). In the same year, Engel published a short article in the newspaper Unsere Heimat (Engel 1930c). It was submitted for printing together with drawings, but the editors decided to publish the article itself; a note from the editors on this matter has been preserved in the Engel archive (DSHI 100 Engel 178, p. 1). A brief reference to the archaeological research at Perdollen also appears in Engel's report on the activities of the Prussia-Museum, in which he mentions the site as containing skeletons from phases B and C (Engel 1931, p. 9). Engel mentions Perdollen in a monograph on the prehistory of the Prussian peoples, citing the site discovered there as an example of the presence of stone circles around flat graves from the Roman period, which was supposed to refer to older, early-iron traditions (Engel 1935, p. 93). He also mentions that a drawing of such an object would be included in the second volume of the study, which, however, was never published. This drawing has been preserved in Engel's papers, although it is not faithful documentation of the object, but rather an idealised reconstruction (Grenz archive, book 86, Fig. 11.2). Perdollen is also mentioned in the catalogue of archaeological sites from the Roman period by Wolfgang La Baume and Carl Engel (1937, p. 262). Information on the site can also be found in the monograph by Haari Moora (1938, p. 52). These are comments given to him by Engel regarding the funeral rite, as well as random information about several objects. In recent years, an article by Olga Khomiakova was published about relationships between the establishment of sites by the people of Dollkeim-Kovrovo culture and the appearance of the landscape (Khomiakova 2016). There are some references to the Perdollen cemetery in this article. The author went to Petino (formerly Perdollen), located the cemetery, and discovered a contemporaneous settlement (Khomiakova 2016, p. 71, Fig. 6.1-2). Khomiakova located the cemetery using the plan found in archival sources (Khomiakova 2016, p. 71,

\footnotetext{
I have not see $\mathrm{n}$ this article.
}

Fig. 7; 1.3), and the settlement by conducting surface surveys.

Archival materials provide an invaluable supplement to published mentions of the discoveries at Perdollen. There is a large file in the MVF containing archives from the Prussia-Museum concerning the research conducted in the village (SMB-PK/MVF, PM-IXd8, PM-A 1186/1). The 65 pages of documents include fragments of a badly damaged diary of Engel's excavations from his research carried out in 1930, with descriptions of objects in pencil and sketches of plans (Fig. 2) ${ }^{4}$. Most of the drawings are not to scale, but some were drawn on graph paper, to a scale of $1: 20$, and there are also individual photographs of objects, unfortunately without descriptions.

The folder also contains many letters, some between the director and the staff of the Prussia-Museum and teachers from the Perdollen area. The oldest are from the 1920s, the latest from 1932. There are also official letters from Gaerte, the director of the Prussia-Museum, to the East Prussian authorities, in which he asks for support in protecting the cemetery. The analysis of all these documents has allowed us to recreate the history of research at Perdollen, in which even a crime story appeared! In addition, a photograph of several finds from Perdollen has survived (SMB-PK/MVF, PM-IXB, PM-F, photograph 1915) in the photograph collection, which is part of the scientific heritage of the Prussia-Museum.

A lot of information about the research at Perdollen was also provided by Grenz's legacy in the MfA. The archive has preserved, among other things, articles transcribed by Grenz, and other published references to archaeological discoveries (Grenz archive, book 86). The photographs taken by Engel during the excavations at Perdollen, described by him on the reverse, are more important; but unfortunately, as a rule, he did not provide the number of the grave. Engel probably wanted to publish some of these photographs in the second volume of his monograph ('Vorgeschichte der altpreussischen Stämme'), which never appeared. This is evidenced by the fact that they have been numbered as if for publication. Furthermore, he copied some of the drawings that Engel had prepared for this publication, marking them as coming from the legacy of Engel (Nachlaß C. Engel / Mat. Carl Engel) and rewriting parts of his legacy devoted to the research at Perdollen. Moreover, there is an unpublished and extremely

\footnotetext{
4 Pencil drawings made by Engel for the article have been redrawn and graphically prepared. The colour brown marks the borders of grave pits and organic layers (e.g. coffins), grey the upper stone pavement layers, and red the lower pavement layers. The word definition introduced by Engel, originally in German, was rewritten in the English language.

5 A copy of this photograph is kept in the legacy of Grenz (archive, box described as Grenz-Archive-Photographs + Negative).
} 


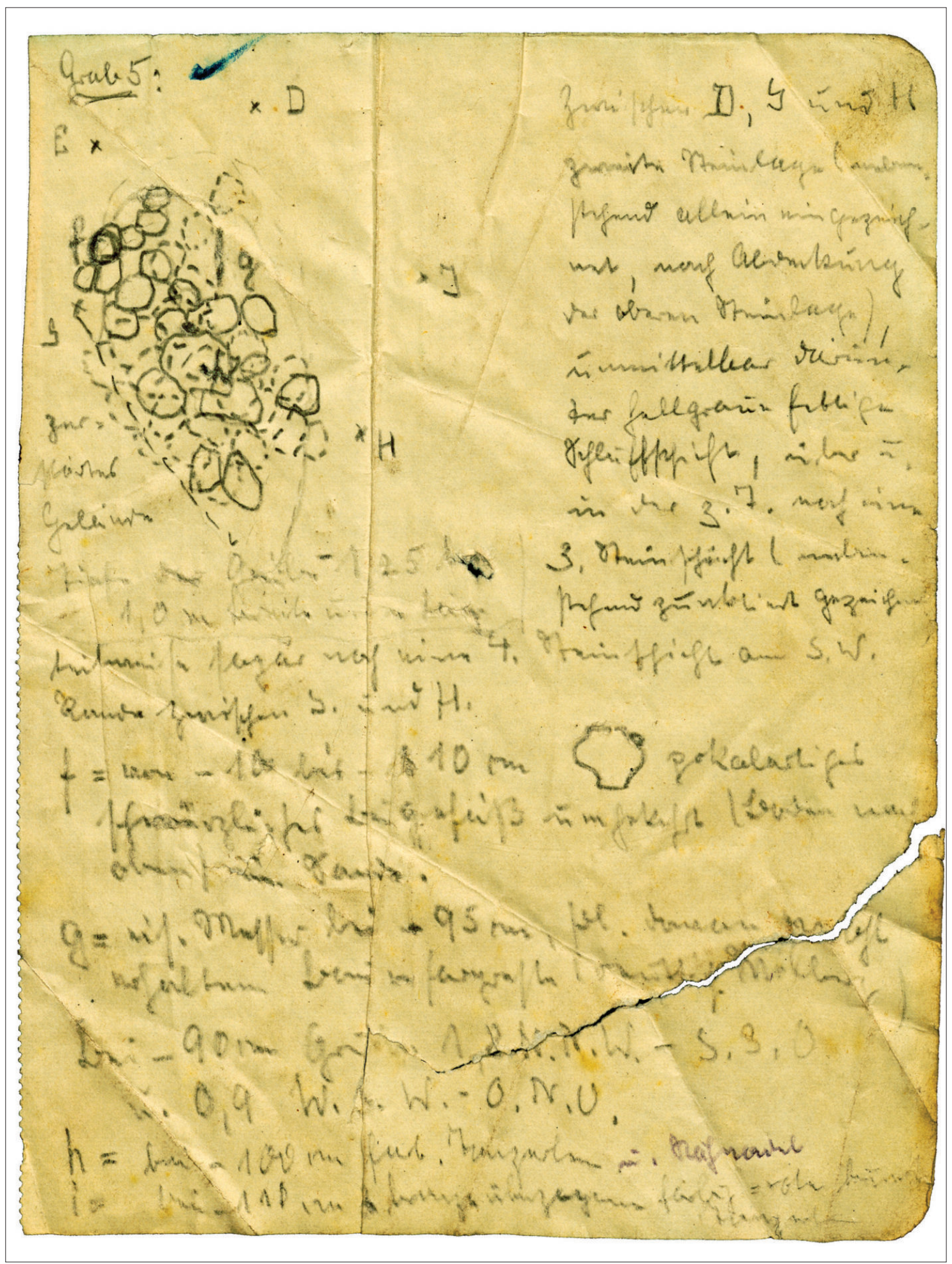

Figure 2. A page from Engel's excavation diary concerning grave 5 (SMB-PK/MVF, PM-IXd8, PM-A 1186/1).

interesting catalogue in Grenz's legacy of archaeological discoveries in the former Kreis Labiau (Grenz archive, the book 'Kreis Labiau'). This is a huge volume that should be edited and published, because we know almost nothing about the archaeological material from this region. The volume also contains much information about the dis- coveries at Perdollen, which complements the previously described data collected by Grenz.

Parts of Engel's scientific legacy are a valuable source of knowledge about the discoveries at Perdollen, but they are not as extensive as the sources mentioned above. There are newspaper cuttings in the Herder-Institut with 
Engel's articles on the excavations (DSHI 100 Engel 178, p. 1). The MfA holds notes by Engel (Engel, archive) with some references to the chronology of the cemetery, and lists with inventory numbers of artefacts. Moreover, two photographs of the site have survived in Engel's legacy in Göttingen (CAEG, pp. 561-562).

Further archival inquiries also yielded some results. In the legacy of Herbert Jankuhn (archive), there is a note with a drawing and information about one bracelet from Perdollen (Fig. 5.1). More cards can be found in the materials of Marta Schmiedehelm (archive). They contain sketches of selected finds and information on selected grave inventories. These notes, however, are quite a mess; but consultation with other sources made it possible to organise the data. The information provided by Schmiedehelm on museum inventory numbers, which were usually omitted in other sources, is extremely valuable. Among the photographs of the scientific legacy of the Teaching Collection of the former Archäologische Kabinett der Universität Tartu, there is a photograph showing several finds from Perdollen (Teaching Collection 4221, Figs. 2-5).

\section{A history of discoveries at Perdollen}

The first information on finds from Perdollen reached the Prussia-Museum in the 1920s. On 19 October 1926, Walter Gronau, a teacher from Conradswalde (Konstantinovka, Gur'evsk district/Conradswalde/Konradswalde, Kr. Labiau) sent a letter to Gaerte, the director of the Prussia-Museum, in which he informed him that the local economic officer (Wirtschaftsbeamter) Rudolf Iwan had found three bronze items at Perdollen (SMB-PK/MVF, PM-IXd8, PM-A 1186/1, p. $3^{6}$ ). They were handed over to the Prussia-Museum (cat. II/1, II/2, II/3). Gronau warned Gaerte that the place where these finds were discovered had been systematically destroyed by the extraction of soil. The director of the Prussia-Museum responded to these reports almost immediately. On 4 November 1926, he sent a letter (SMB-PK/MVF, PM-IXd8, PM-A 1186/1, p. 4) directly to Iwan, in which he informed him that the bronze objects he had discovered were two brooches and a bracelet from the 3 rd century AD. He also expressed his concern, saying that it would be highly disadvantageous if the site he interpreted as a cemetery was still being destroyed by digging. At the same time, he informed Iwan that a technician (Präparator) from the Prussia-Museum would be sent to Perdollen. This is how Josef Wilczek came to the village.

The scientific collection of the Prussia-Museum includes a short report by Wilczek on his one-day trip to Perdollen

\footnotetext{
${ }^{6}$ The article uses the numbering of digitised scans of Perdollen cards from the scientific collection of the Prussia-Museum.see https://akademieprojekt-baltikum.production.easydb.de/.
}

(SMB-PK/MVF, PM-IXd8, PM-A 1186/1, pp. 5-7). We learn from it that on the morning of 4 November 1926, at 6.20 am, Wilczek set off by train from the Eastern Railway Station in Königsberg to Yorksdorf (Jorksdorf/Yorksdorf, $\mathrm{Kr}$. Labiau, no contemporary name), where he arrived at $8.19 \mathrm{am}$. The town was located approximately three kilometres from Perdollen (Fig. 1.2). At Perdollen, he met Augstein, a local landowner who was unable at first to provide him with information about archaeological discoveries. However, he remembered that the landowner Iwahn (according to Gronau, Iwan) had found a cross in 1918 or 1919 while digging gravel. The cross came from a place that local people called Dangulaukies. It was allegedly a small hill, about 1.5 morgen in size, covered by a small forest (about $50 \times 28 \mathrm{~m}$ ). Engel described where the hill was located. It was at a latitude of two-kilometre stones - 10.9 $\mathrm{km}$ and $11 \mathrm{~km}$ on the road from Labiau (Polessk) through Mehlauken (Zales'e) to Tilsit (Sovetsk), approximately five kilometres from the railway station in Schelecken (Sholokhovo). According to information from Wilczek's report, Heerstraße Street once stretched to the west of Dangulaukies, but it did not exist any more when Wilczek came to Perdollen. A flat cemetery was located about 100 metres from Dangulaukies, partly on Iwahn's land, and partly in the gravel pit (Fig. 3.1). It was almost completely destroyed by local people excavating gravel and sand: Wilczek saw long digs there.

We also learn from Wilczek's report that the first finds at Perdollen were not in the 1920s, or even from 1918 or 1919, but from 1895 or 1896, when some artefacts and bones were found in the aforementioned Heerstraße. Fragments of human skulls and small vessels of various colours were discovered (cat. I/1). So at least two archaeological sites were discovered at Perdollen: the first was on Heerstraße (site I), and the second was in the gravel pit and on Iwahn's land, a destroyed flat cemetery of Dollkeim-Kovrovo culture (site II). Wilczek sketched where the cemetery from the Roman period was located (SMB-PK/MVF, PM-IXd8, PM-A 1186/1, p. 7; Fig. 1.3).

Three years after Wilczek's visit to Perdollen, on 7 December 1929, the teacher (Lehrer, Kreispfleger Labiau Ost) E. Grünberg from Laukischken (Saranskoe) near Perdollen (Fig. 1.2) sent a letter to Gaerte (SMB-PK/MVF, PM-IXd8, PM-A 1186/1, pp. 8-9; cf. Engel 1930a; 1930b). He reported that he had found many fragments of pottery in the Perdollen gravel pit, approximately 400 metres south of the road leading from Labiau to Mehlauken (cat. III). Interestingly, these discoveries were made almost half a year before the letter was sent, on 11 and 12 May 1929. Grünberg correctly identified the nature of the archaeological site, describing it as a flat cemetery. It follows from the rest of the letter that on 11 August 1929, Grünberg went to the gravel pit, and saw that its edge had been washed away by rain, revealing rotten urns containing bones. They 


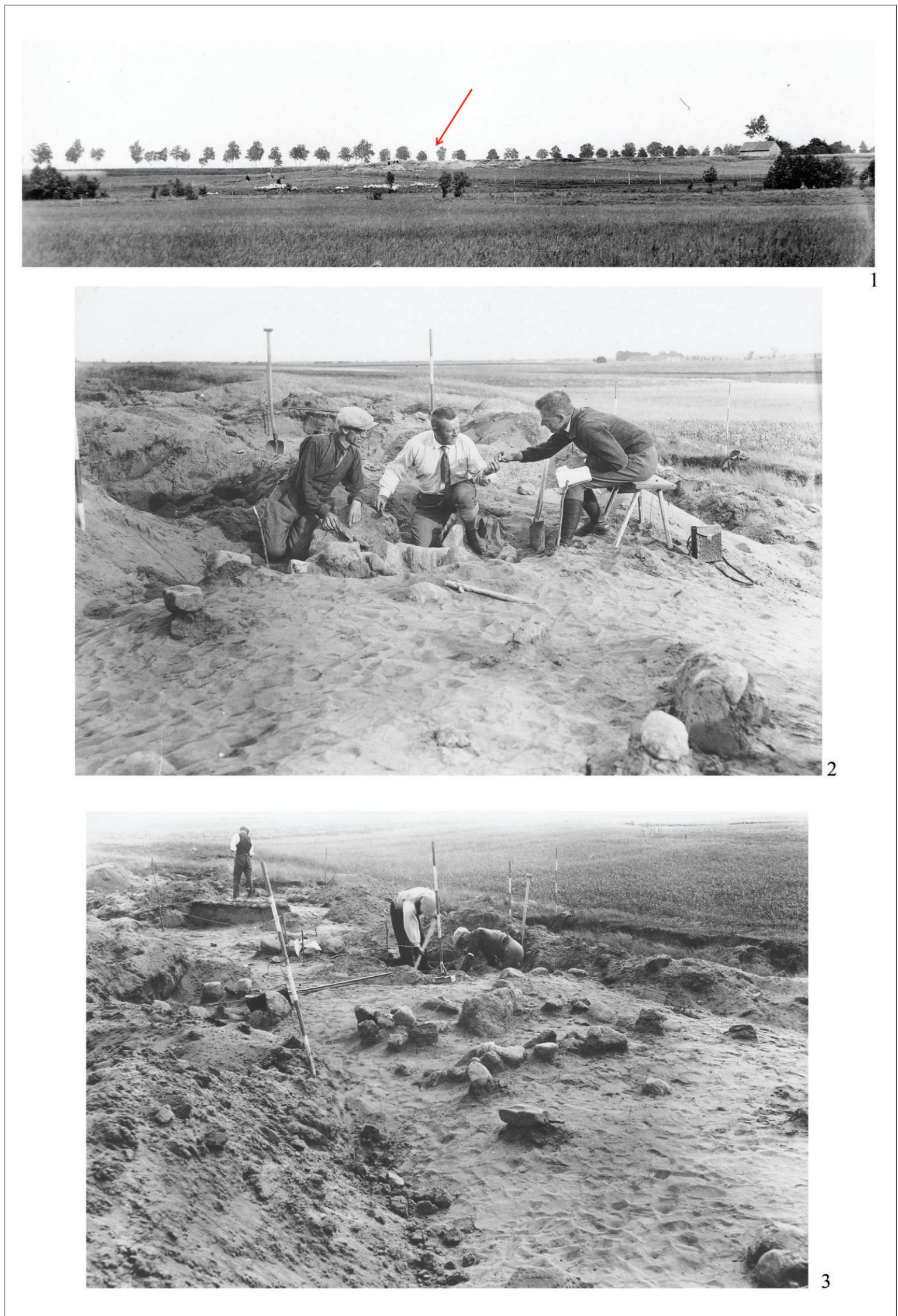

Figure 3. 1. the gravel pit at Perdollen where part of the cemetery was located; 2 . the excavations at Perdollen, 15 July 1930 (from left: Jaensch, the teacher Grünberg, Engel); 3. the excavations at Perdollen, 14 July 1930 (Grenz archive, book 86). 
were poorly made and stripped of decoration. Despite his search, Grünberg found no other objects. He collected only a few fragments of these vessels. On 11 September 1929 , Grünberg went to the gravel pit again, where he discovered eight already-excavated objects, but there is no mention of finding any relics. On the other hand, during his next visit, on 24 October, about 150 metres northeast of these dug-up objects, in a field next to the gravel pit, he found black soil with fragments of pottery, probably the remains of destroyed cremation graves, most likely urn graves (cat. III/3).

Another document on the discoveries at Perdollen (SMBPK/MVF, PM-IXd8, PM-A 1186/1, p. 10) is from 24 May 1930. It is a letter written by Gaerte to Grünberg, in which he informed him that his assistant Engel, and also Wilczek, would come to Perdollen on 26 May 1930 (a Monday), and would conduct excavations. In this letter, Gaerte asked Grünberg to find two workers to help Engel with the work. They had to be waiting on Monday at 10 am at the local school, and be available to Engel all day Monday, and possibly also on Tuesday morning. Gaerte also asked Grünberg about the possibility of accommodation for Engel and Wilczek in an inn (Gasthaus) in Laukischken.

In Perdollen in May 1930, Engel and Wilczek learned from a man called Frick about illegal digging at the cemetery (SMB-PK/MVF, PM-IXd8, PM-A 1186/1, p. 35). In May, they excavated (Fig. 4.1,2) at least 12 objects (cat. IV/1-12). Some parts of the excavation documentation have preserved in the Prussia-Museum archive (SMB-PK/ MVF, PM-IXd8, PM-A 1186/1, pp. 12-30). After returning to Königsberg, Engel published two short articles on the research (Engel 1930a; 1930b). According to him, inhumation graves from the 1 st and 2 nd centuries $\mathrm{AD}$ had been discovered at Perdollen. Skeletons were surrounded by stone circles about five metres in diameter. They were found at a depth of one metre in pure sand, and were occasionally covered with stone pavements. The deceased were buried in wooden coffins about two metres in length. Moreover, according to Engel, coloured ton beads, bronze brooches, bronze belt-end fittings and buckles, iron knives, and needles were discovered in the graves. In one grave, in the place where the head should have been, a very beautiful, richly ornamented ton cup was found (von samländisch-weichselländischer Form Engel 1930a; 1930b; cat. IV/7/1; Fig. 9.6). Engel also described another object: a richly furnished grave of a rider and a horse (cat. IV/10). The horse was lying on the right of the man, with the head directed towards the south, and the man was lying with the head to the north. Near his head were lying grave goods: iron spurs, buckle, a battleaxe, a spearhead and a whetstone. An iron bit connected to a bridle decorated with bronze fittings (Bronzebeschlagplättchen - Engel 1930a; 1930b) was discovered between the horse's teeth. Moreover, many burnt human bones and pottery sherds were discovered between stones covering inhumation graves at the cemetery, which, according to Engel, might have been sacrifices.

Undoubtedly, both Engel and Gaerte realised that the cemetery had not been fully explored in the course of the twoday excavation. A handwritten note from Engel (SMB-PK/ MVF, PM-IXd8, PM-A 1186/1, p. 36) has survived, in which he wrote that he had to show Gaerte the cup found at Perdollen (cat. IV/7/1), and asked him to close the Perdollen gravel pit, as it was destroying the cemetery. He also planned to invite him to further excavation work at Perdollen. Engel contacted Gaerte, as is evidenced by a letter written by the director of the Prussia-Museum on 30 May 1930 (just a few days after Engel's return to Königsberg) to a representative of the inhabitants of Perdollen ( $A n$ den Herrn Gemeindevorsteher in Perdollen, Kreis Labiau SMB- PK/MVF, PM-IXd8, PM-A 1186/1, p. 33). Gaerte ordered the operation of the gravel pits to be halted, and the area to be protected from robbers.

A week later, in a letter dated 7 June 1930, Gaerte informed the district president (Regierungspräsident) that the Perdollen cemetery was being destroyed by the local population, by robbery and gravel excavation (SMB-PK/MVF, PM-IXd8, PM-A 1186/1, p. 37). It is not known whether he was reporting on the situation that took place before Engel's research, or whether he received any new information. On 12 June 1930, the district governor (Landrat) at Labiau informed Gaerte that on 29 May, i.e. shortly after the completion of Engel's excavations, he decided to close the gravel pit, and indicated that the gendarmes (Landjägereibeamten) would monitor the place. On 18 June, the district president wrote a letter to Gaerte (SMB-PK/MVF, PM-IXd8, PM-A 1186/1, p. 40), in which he asked him to provide further information on the results of the excavations. He made this request again on 27 November (SMBPK/MVF, PM-IXd8, PM-A 1186/1, p. 50).

In the following days of June 1930, Grünberg contacted the Prussia-Museum again. Unfortunately, this part of the correspondence has not been preserved, but Engel's reply of 10 June 1930 to Grünberg exists (SMB-PK/MVF, PMIXd8, PM-A 1186/1, p. 39). Engel wrote that the authorities had successfully closed the gravel pit, but at the same time asked Grünberg to make sure the cemetery was not destroyed. In addition, he mentioned the planned excavations, saying that it was not certain when they would take place. In addition, at Grünberg's request, he sent him some of the excavation documentation from the research carried out in May.

Shortly afterwards, on 7 July, Gaerte informed Rudolf Krause from Permauern (Lomonosovka) that in two days (on 9 July) Fritz Jaensch would come to Perdollen and continue the excavation work in the cemetery. In the 


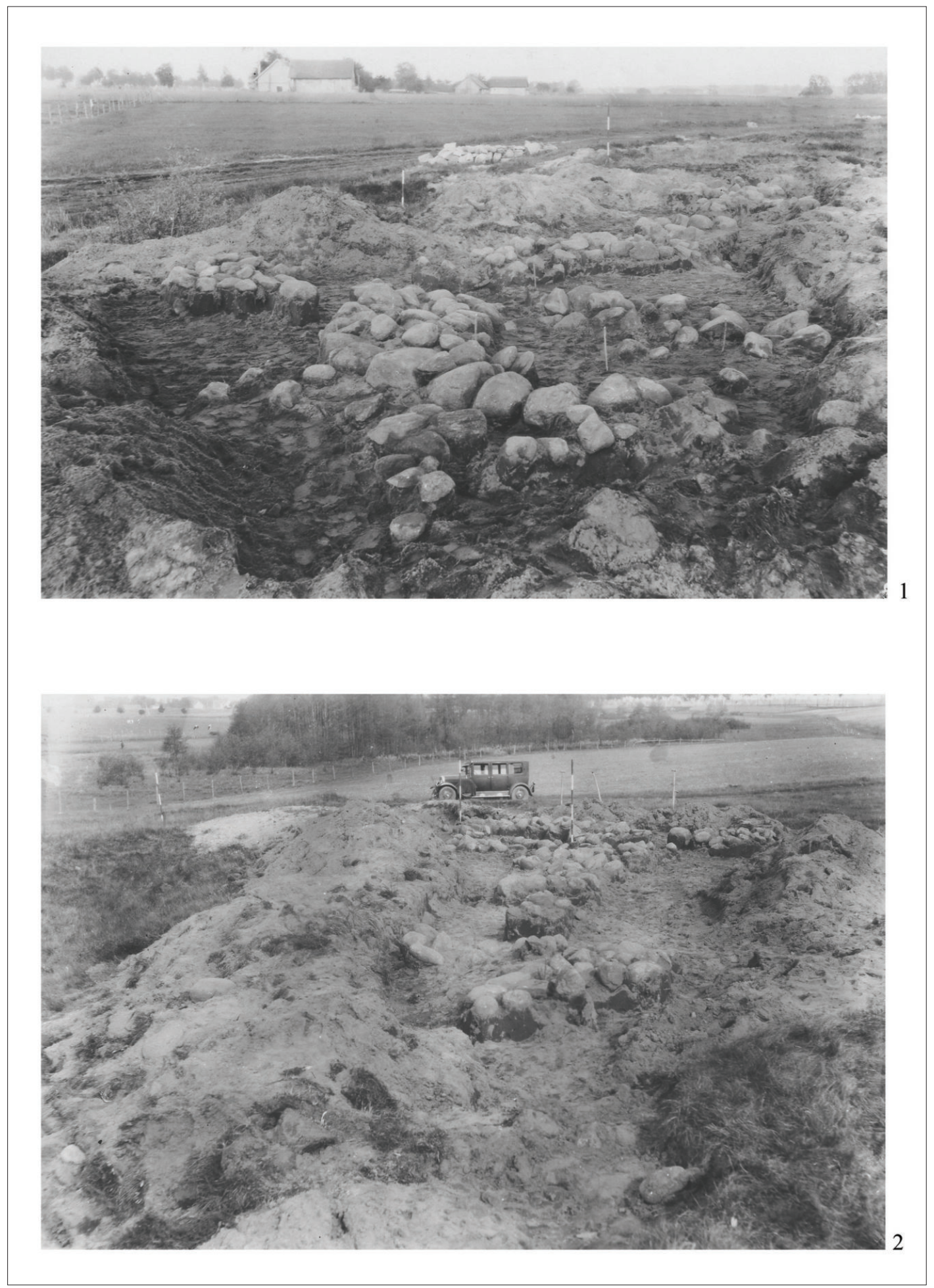

Figure 4. 1. the cemetery at Perdollen, seen from the west (graves 1-7 visible), photograph taken on 26 May 1930; 2. the view from the east (graves 1-7 visible), photograph taken on 27 May 1930 (Grenz, archive, book 86).

letter, Krause was asked to wait for Jaensch at the gravel pit at 10 am (SMB-PK/MVF, PM-IXd8, PM-A 1186/1, p. 42). On the same day, another letter was sent from the Prussia-Museum to Grünberg, in which he was informed about the planned arrival not only of Jaensch on 9 July, but also of Engel on 10 July (SMB-PK/MVF, PM-IXd8, PM-A 1186/1, p. 43). Grünberg was instructed to provide two people to help with the excavation work, who should be waiting for Jaensch at 10 am on 9 July in front of the school (presumably in Laukischken). The teacher was also asked to book Jaensch an overnight stay on 9-10 July in the inn, and Engel on 10-11 July. The letter stated that the excavations would only take two days. In fact, they lasted four days, but with a short break: they were conducted on 
9-10 and 14-15 July (SMB-PK/MVF, PM-IXd8, PM-A 1186/1, p. 47; Engel 1930d; 1930e).

During the excavations carried out in July (Fig. 3.2, 3), Engel continued the numbering of objects that had begun in May that year (cat. V). Among the graves from the Roman period, there were at least two modern graves (graves $\mathrm{J}$ and $\mathrm{K}^{7}$ ) containing well-preserved skeletons in wooden coffins with iron nails. Engel was not sure what period they belonged to. He thought they could be either the graves of plague victims (Pestzeit) or the graves of soldiers from 'one of the wars'. According to Engel, the latter hypothesis was supported by the fact that on the former Heerstraße (site I), which ran directly along the edge of the cemetery, similar skeletons and also curved sabres were once allegedly found (Engel 1930d; 1930e). Apart from a few photographs of some objects (Grenz archive, book 86), the documentation of the research conducted in July has not been preserved. The descriptions of these photographs do not contain the numbers of the graves. In addition, question marks appeared in many of Engel's captions, because he probably could not remember which grave was photographed. Working with this part of the documentation is extremely difficult. Additionally, the photographs are mixed with photographs of the graves excavated in May. Engel published the results of the discoveries made in July in two short articles (Engel 1930d; 1930e). We learn from them that small regular pits with decomposition traces (Verwesungsgruben) covered with stone pavements were discovered next to inhumation graves. According to Engel, these might be animal sacrifices. The cremation graves were especially interesting to Engel. Some single urns were surrounded by stone circles, and some urns were stacked in groups in stone chests. Engel noticed that these stone constructions and the funeral rite were very similar to what is known from the Earliest Iron Age.

It is difficult to say how many graves were discovered in July, but the entire cemetery was certainly not examined. Therefore, on 18 July 1930, Gaerte asked the district president, the head of the provincial government (Landeshauptmann), and the Labiau district governor, to extend the decision to close the part of the gravel pit that had not been investigated by Engel (SMB-PK/MVF, PMIXd8, PM-A 1186/1, p. 47). However, he wrote that the local population may be extracting gravel in the part of the gravel pit that was already investigated. In this letter, Gaerte indicated that the representative of the local people showed his support for this solution. Gaerte probably received a positive decision from the authorities, because three days later (21 July), he sent a letter to a representative of the local community with a request to extract gravel only in places that had already been excavated by Engel

Since the numbers of many graves that were excavated in July are unknown, the catalogue gives them letters (A-K). and Jaensch. These places would be indicated by Grünberg.

After the July research season, Engel published two short articles on the results of the research at Perdollen (Engel 1930d; 1930e). Then six months later (in November 1930), he sent an extremely kind letter to the landowner (Gutsbesitzer) Hinz at Perdollen, in which he apologised for not having sent him data about the results of the excavations (SMB-PK/MVF, PM-IXd8, PM-A 1186/1, p. 49). He wrote that he wanted to send him the published article in the newspaper Unsere Heimat (Engel 1930c), but unfortunately he did not have a copy of his own, so he sent the manuscript of his article with the letter, with two photographs of the cemetery attached. He also thanked Hinz for his hospitality.

After the July excavation expedition, further research was planned at Perdollen, but unfortunately it did not take place. In November 1930, the district president sent a letter to Gaerte asking for further information on the results of the excavations (SMB-PK/MVF, PM-IXd8, PM-A $1186 / 1$, p. 50). This concern on the part of the authorities was probably caused by the continued closure of the unexplored part of the gravel pit. Gaerte wrote back, saying that no further investigations had taken place, and asked to keep part of the gravel pit closed (SMB-PK/MVF, PMIXd8, PM-A 1186/1, p. 51).

It is hard to say why there was no further research. Undoubtedly, Engel was also busy with other fieldwork. However, further finds from the Perdollen cemetery were sent to the Prussia-Museum by local people. Grünberg informed Gaerte that on 26 September 1931, in the closed, i.e. archaeologically unexplored, part of the gravel pit, he saw two robbery ditches and the remains of a cremation pyre and burnt bones (Knochenasche verweist auf evtl. Fund hin - SMB-PK/MVF, PM-Ixd8, PM-A 1186/1, p. 52). In the following months (November 1931 and February 1932), the district president sent Gaerte a letter and an unkind (!) admonition requesting a report on the progress of the research at Perdollen (SMB-PK/MVF, PM-Ixd8, PM-A 1186/1, pp. 53-54). Gaerte wrote back saying that the state of research on the cemetery had not changed since July 1930 (SMB-PK/MVF, PM-Ixd8, PM-A $1186 / 1$, p. 55). Later on, Gaerte sent another note to the authorities, in which he wrote that he had been informed by Grünberg about robbery excavations in the closed part of the gravel pit (SMB-PK/MVF, PM-Ixd8, PM-A 1186/1, p. 56). In this letter, referring to the law, he asked for the perpetrator to be found and punished. Later on, in March 1932, Gaerte contacted the teacher (Lehrer und Kreispfleger) Lieck from Labiau, and informed him that he had accidentally (!) found out about the robbery of the cemetery at Perdollen, and that he had asked the authorities to punish the perpetrators. He also asked Lieck for help 
in finding them (SMB-PK/MVF, PM-IXd8, PM-A 1186/1, p. 57). A few days later, Gaerte wrote a letter to Grünberg, in which he thanked him for the information about the robbery, and informed him that he had contacted the authorities and Lieck, emphasising, however, that he had not revealed how he knew about the robbery (SMB-PK/ MVF, PM-IXd8, PM-A 1186/1, p. 58). In April 1932, the authorities sent a letter to Gaerte, stating that the local gendarme had said that there were no robbery trenches in the closed part of the gravel pit (SMB-PK/MVF, PM-IXd8, PM-A 1186/11, p. 59). The whole story is quite puzzling. It is difficult to say whether the site was robbed or not, but for almost two years the Prussia-Museum put off carrying out excavations, and the local population could not use the gravel pits fully. Certainly, it caused dissatisfaction among the authorities, who turned to Gaerte many times, and also among the local population. So they might have destroyed the cemetery on purpose.

On 17 April 1932, the owner of the field next to the gravel pit informed Grünberg that he had found beads in ploughed furrows. He also stated that he was about to start planting potatoes in the field. As these actions would certainly destroy any archaeological objects, a day later, on 18 April, Grünberg called Engel, who gave him permission to carry out rescue excavations (SMB-PK/MVF, PM-IXd8, PM-A 1186/1, p. 65). Grünberg made measurements on the same day, and the next day he carried out rescue excavations. The report and the drawing documentation were sent to Gaerte (SMB-PK/MVF, PM-IXd8, PM-A 1186/1, pp. 60-61). Grünberg examined one grave (cat. VI), uncovered as a result of the collapse of a heap of gravel (Schutthang) due to heavy rain. Part of the object was outside the heap, in an arable field, and it was destroyed in that part by ploughing. There were numerous beads in the furrows. Grünberg drew up a detailed drawing of the site's plan and profile, and also marked the place where artefacts were discovered (for this see Fig. 19). Undoubtedly, he had some knowledge of prehistory, because in the aforementioned letter to Gaerte, he asked him to say what period the finds came from, phase B or C (!). He also asked Gaerte if at least some of the discovered artefacts might find their way to the Heimatmuseum in Labiau, but at the same time he sent them back to the Prussia-Museum together with the research report. Gaerte explained to Grünberg that he had discovered a phase $\mathrm{C}$ skeleton grave (SMB-PK/ MVF, PM-IXd8, PM-A 1186/1, p. 64). He also wrote that the prehistory of the Labiau district is extremely poorly researched (which, unfortunately, also applies today), and as the director of the museum, he would be reluctant to give the artefacts to another institution. However, in recognition of Grünberg's work, Gaerte proposed to donate a model collection (Modellserie) of archaeological finds to a school (probably in Laukischken). He asked Grünberg to choose whether he was interested in a collection of items from the Stone Age or the Bronze Age. There is no reply to this letter.

However, this is not the end of the archaeological discoveries at Perdollen. A note has been preserved in the legacy of the Prussia-Museum, judging by the handwriting, written by Jankuhn (SMB-PK/MVF, PM-IXd8, PM-A $1186 / 1$, p. 2), according to which on 23 October 1933, students from a local school discovered graves with stone structures (cat. VII). They were exposed by landslides in the gravel pit due to heavy rain. The children then found several items that were donated to the Prussia-Museum. It is likely that some of these finds came from the cemetery from the Roman period, and some from modern graves in the former Heerstraße. So far, there is no information about the later finds from Perdollen, but it is certain that none of the sites there have been fully investigated.

\section{Catalogue}

\section{Perdollen, site I (Heerstraße) ${ }^{8}$}

I. Stray finds from a destroyed, probably modern, cemetery with inhumation graves. Small vessels (1) and skull bones were found in the pits in Heerstraße in 1895 and 1896.

Inventory: 1) small ton vessels; different colours; Dm. 6-9 cm.

Chronology: modern times (?).

Collection: not donated to any museum.

Sources: SMB-PK/MVF, PM-IXd8, PM-A 1186/1, p. 6.

Perdollen, site II (flat cemetery)

\section{Finds discovered before 19 October 1926}

Finds discovered by Iwan, economic officer (Wirtschaftsbeamter) from Conradswalde; given to the teacher Gronau, who donated them to the Prussia-Museum.

\section{Stray find}

Inventory: 1) bronze bracelet with profiled terminals (Fig. 5.1); ornamented with rows of pseudo-filigree and embossed (?) circles; Dm. $7.3 \mathrm{~cm}$, L. terminals $2.9 \mathrm{~cm}$, W. body $2 \mathrm{~cm}$; max. T. body $0.3 \mathrm{~cm}$.

Chronology: B2 -B2/C1-C1a.

\footnotetext{
8 The catalogue distinguishes material from successive years of research and accidental discoveries; Roman numeration was used. The following typological systems were used: fibulae, Oscar Almgren (1897) with supplements by Michel Feugère (1985) concerning disc fibulae; beads, Magdalena Tempelmann-Mączyńska (1985); finger-rings, Christamaria Beckmann (1969), buckles and belt-end fittings, Renata Madyda-Legutko (1987; 2011); belt mounts, Jochen Garbsch (1965).
} 


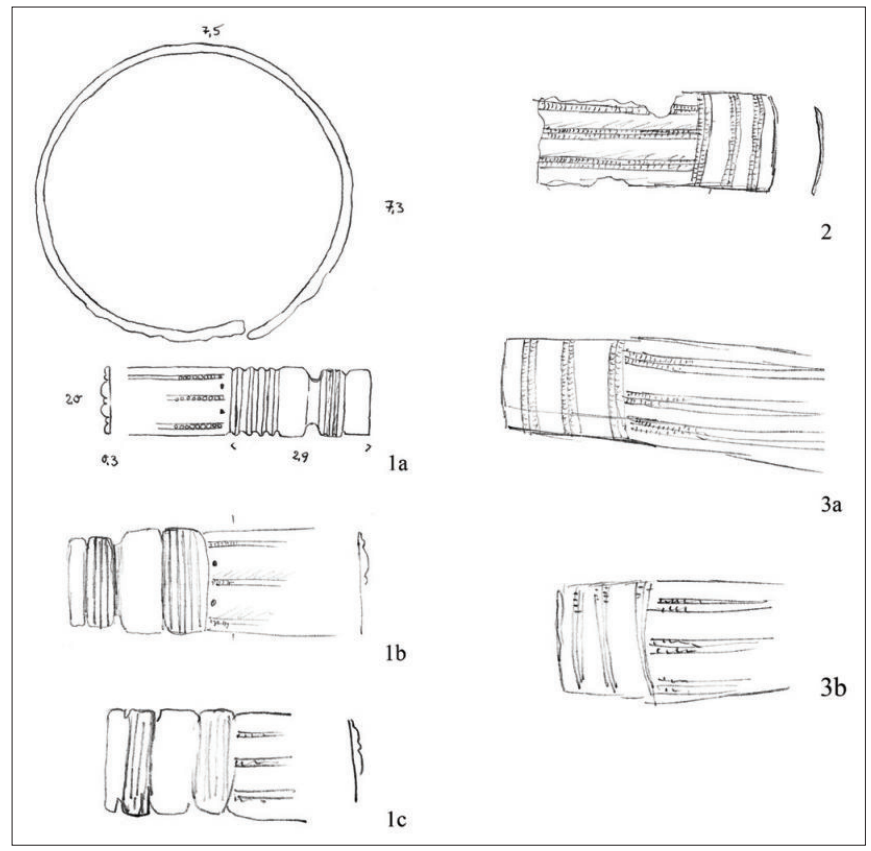

Figure 5. Bronze bracelets found at Perdollen: 1. stray find (cat. II/1/1). 2. context unknown (cat. V/15/1). 3. grave L (cat. VI/1/1-3) (1a Jankuhn archive; others Schmiedehelm archive. No scale).

Collection: Prussia-Museum, inv. No PM III,107,9651 / VII,107,9651 / VII,167,9651; the find is considered lost.

Sources: SMB-PK/MVF, PM-IXd8, PM-A 1186/1, pp. 3-4; DSHI 100 La Baume 9, p. 20; Jankuhn, archive; Schmiedehelm, archive 7.13d.388, 7.25.47.182, 7.25.51.122.

Comments: according to Jankuhn, the bracelet had inv. No VII,107,9651 and according to Schmiedehelm (archive 7.25.47.182, 7.25.51.122) No III,107,9651. The same researcher drew this bracelet (Fig. 5.1c) on one of the cards and added inv. No III,167,9651.

\section{Stray find}

Inventory: 1) bronze fibula A.V.1 ornamented with iron inlay (probably with crests inlaid with iron).

Chronology: B2/C1-C1a.

Collection: Prussia-Museum, inv. No PM III,107,9651 / VII,107,9651 / VII,167,9651; the find is considered lost.

Sources: SMB-PK/MVF, PM-IXd8, PM-A 1186/1, pp. 3-4; Schmiedehelm, archive 7.25.47.182, 7.25.51.122.

Comments: the fibula was handed over to the PrussiaMuseum along with a bracelet (cat. II/1/1), so it most likely received the same inventory number. It was described by Gaerte quite generally as (Gewandspange - SMB-PK/ MVF, PM-IXd8, PM-A 1186/1, p. 4). Schmiedehelm described two bronze fibulae series A.V.1 from Perdollen (2 Sprossenf. M. Eisenbeleg - Schmiedehelm, archive 7.25.51.122), decorated with iron inlay, which in the Prussia-Museum had inv. No PM III,107,9651. The catalogue assumes that the two fibulae described by Schmiedehelm are brooches from Iwan's area, donated to the Prussia-Museum before 1926 .

3. Stray find

Inventory: 1) bronze fibula A.V.1 ornamented with iron inlay (probably with crests inlaid with iron).

Chronology: B2/C1-C1a.

Collection: Prussia-Museum, inv. No PM III,107,9651 / VII,107,9651 / VII,167,9651; the find is considered lost.

Sources: SMB-PK/MVF, PM-Ixd8, PM-A 1186/1, pp. 3-4; Schmiedehelm, archive 7.25.47.182, 7.25.51.122.

Comments: cat. II/2.

\section{Finds discovered in 1929}

Stray finds and destroyed graves discovered in the flat cemetery in the area of the gravel pit by the teacher Grünberg from Laukischken in 1929 on 11-12 May (1), $11 \mathrm{Au}-$ gust (2) and 24 October (3).

\section{Stray finds/destroyed urn graves}

Inventory: 1) many pottery fragments (mehrere Urnenscherben).

\section{Chronology: (?).}

Collection: probably not donated to any museum.

Sources: SMB-PK/MVF, PM-IXd8, PM-A 1186/1, p. 8.

2. Stray finds/destroyed urn graves

Vessels (1) with bone fragments found on the edge of the gravel pit, which was destroyed by heavy rain. 
Inventory: 1) very delicate ton vessels (Urnen); surface raw, not decorated.

Chronology: (?).

Collection: Prussia-Museum, inv. No unknown (?); the finds are considered lost.

Sources: SMB-PK/MVF, PM-IXd8, PM-A 1186/1, p. 8.

Comments: Grünberg collected some fragments; others were excavated later by Engel in 1930.

\section{Stray finds/destroyed urn graves}

Pottery fragments (1) found in the field by the gravel pit in black soil, approx. $150 \mathrm{~m}$ to the $\mathrm{N}$ from finds III/1 and III/2.

Inventory: 1) pottery fragments (Urnenscherben).

Chronology: (?).

Collection: not donated to the museum.

Sources: SMB-PK/MVF, PM-IXd8, PM-A 1186/1, p. 8.

IV. Excavations carried out by Engel and Wilczek, 2627 May 1930

\section{Grave 1}

Inhumation grave (?), partly covered by a few stones in the northern part (Figs. 6 and 17); by the western part of the grave, longitudinal stone pavement ca. $225 \mathrm{~cm} \mathrm{NS} \times \max$. $132 \mathrm{~cm}$ EW; oval grave pit at a depth of $50 \mathrm{~cm}$, ca. $225 \mathrm{~cm}$ $\mathrm{NW}-\mathrm{SE} \times 80 \mathrm{~cm}$ NE-SW; pit filled with grey sand; in the pit, $40 \mathrm{~cm}$ below the surface, eight stones and the grave goods (Fig. 7.1): disc fibula (marked g - 1), rectangular belt part (marked i - 4), four boat-shaped belt mounts (marked d1-4-2-3), and some other unidentified objects (marked f, h, k, l-5-8).

Inventory: 1) bronze disc fibula similar to type Feugère 24c (Figs. 7.2g and 8.4); hinge construction; edge destroyed; in the centre, a pair of concentric circles, similar decoration on the insets around the central part of the fibula; 2) two undecorated, bronze belt mounts, similar to type Garbsch Ka (Figs. 7.2d1, 4 and 8.7); 3) two bronze belt mounts similar to type Garbsch Ka, decorated with engraved lines and grooves, with adjacent leather strap fragments (Figs. 7.2d $2-3$ and 8.6); 4) belt mount or a buckle/clasp fragment (? - Figs. 7.2i and 8.5) composed of four rectangular plates joined by four rivets with large, hemispherical heads; two narrower plates, undecorated, with evenly spaced rivets; the other two plates are more massive, decorated with engraved lines; 5) unidentified object; 6) unidentified object; 7) unidentified object; 8) Unidentified object.

Chronology: B2a-B2/C1-C1a.
Collection: Prussia Museum, inv. No PM VII,172,10458 (Schmiedehelm, archive, 7.25.51.119) / PM VII,300,11935 (Grenz archive, book 86; Teaching Collection); nowadays, the fibula (1) is housed in the MVF, inv. No Pr. 523, the other finds are considered lost.

Sources: Engel 1930c, p. 290; Khomiakova 2015, p. 37, Fig. $5.6^{9}$; 2017, Fig. $3.3^{10}$; Chilińska-Früboes 2020, p. 115; Chilińska-Früboes and Skvortsov, forthcoming 2022; SMB-PK/MVF, PM-IXd8, PM-A 1186/1, pp. 22-23, 26; SMB-PK/MVF, PM-IXb, PM-F, photograph 000191; Grenz archive, book 86; box described as GrenzArchive-Photographs + Negative; Schmiedehelm, archive 7.25.47.182, 7.25.51.119; Teaching Collection, photograph 4221.2-5.

Comments: plans and photograph of the grave have survived, without a description, however. Measurements were taken from drawings. In the scientific legacy of Grenz, there is a photograph (Fig. 7.2) showing the items listed in the catalogue, and, in addition, a fibula type A.59 (Fig. 7.2a), three glass beads of unspecified type (Fig. $7.2 \mathrm{~h}$ ), eight bronze beads in the shape of profiled rings (Fig. 7.2f), a fragment of a needle/pin (Fig. 7.2b), a fragment of a corroded knife (Fig. 7.2c), a flint (Fig. 7.2e), and nine wires (Fig. 7.2j). The photograph is described as geschlossener Grabfund, wahrsch. Samland-Natange. A copy of it, without a description, is kept in the archive of the Prussia-Museum (SMB-PK/MVF, PM-IXb, PM-F, photograph 000191). Thanks to information from the legacy of Schmiedehelm (archive 7.25.51.119) and from the Teaching Collection (photograph 4221.2-5), it was possible to establish that the disc fibula and belt parts (1-4) shown in the photograph were found at Perdollen, in grave 1, while the fibula type A.59 was discovered in grave 12 at the same cemetery (cat. V/1/1; Chilińska-Früboes 2020, p. 115, Plate 293.1; cf. Schmiedehelm, archive 7.25.51.120). It is most likely, then, that the photograph in question does not show the inventory of one grave, but selected items from Perdollen cemetery (Chilińska-Früboes 2020, p. 115).

\section{Grave 2}

Grave covered with four stones, at the area ca. $90 \mathrm{~cm} \mathrm{NW-}$ SE $\times 50 \mathrm{~cm} \mathrm{NE}-\mathrm{SW}$ (Fig. 17); located just by the edge of the gravel pit; the grave was destroyed (?).

\section{Inventory: (?).}

Chronology: (?).

Collection: (?).

Sources: SMB-PK/MVF, PM-IXd8, PM-A 1186/1, p. 23; Grenz archive, book 86.

\footnotetext{
9 The fibula was wrongly described as found at former AlthofInsterburg.

${ }^{10}$ As above.
} 


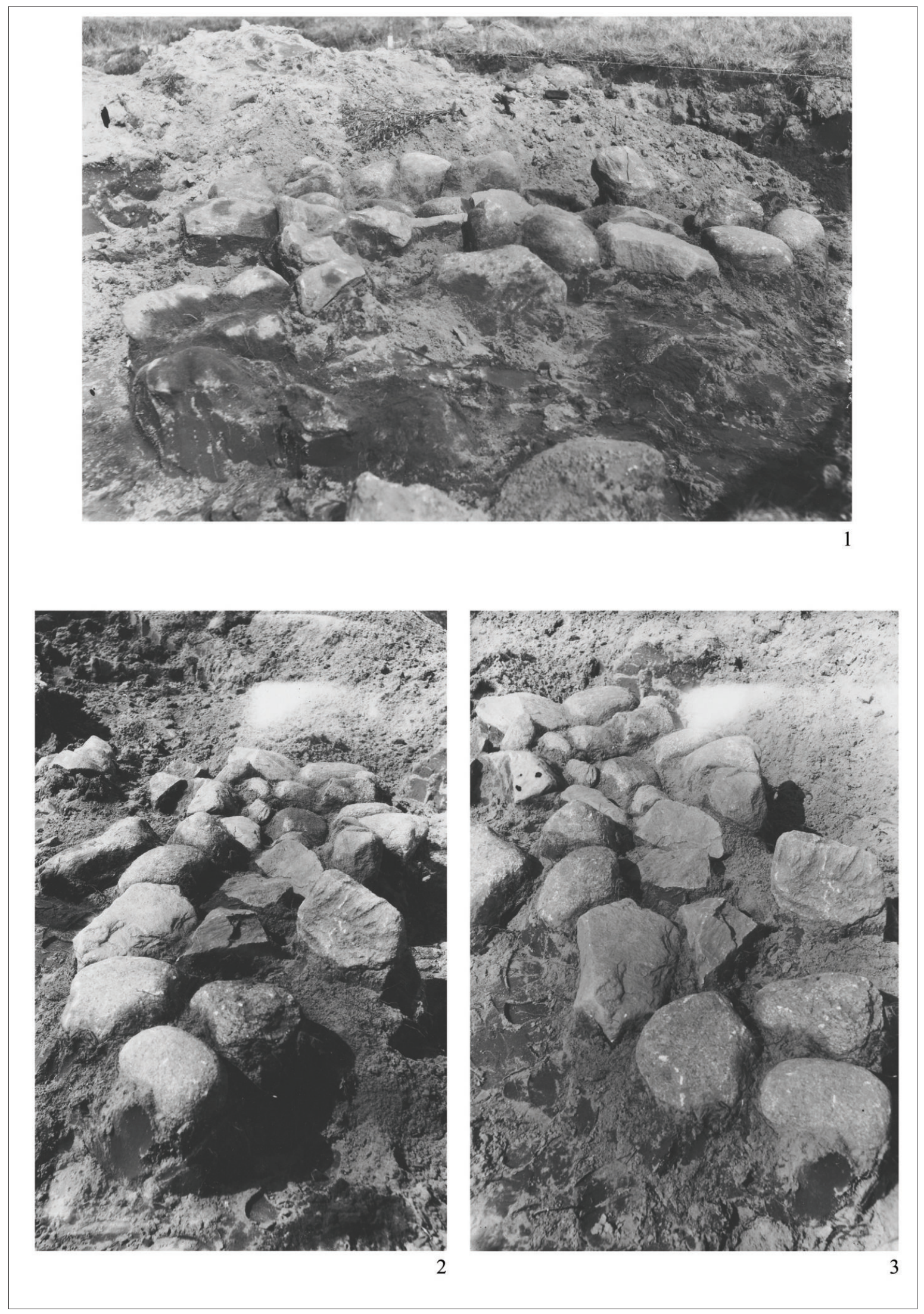

Figure 6. The stone pavement covering grave 1. 1. the view from the west. 2. the view from the southeast. 3. the view from the south. All photographs taken on 26 May 1930 (Grenz archive, book 86). 


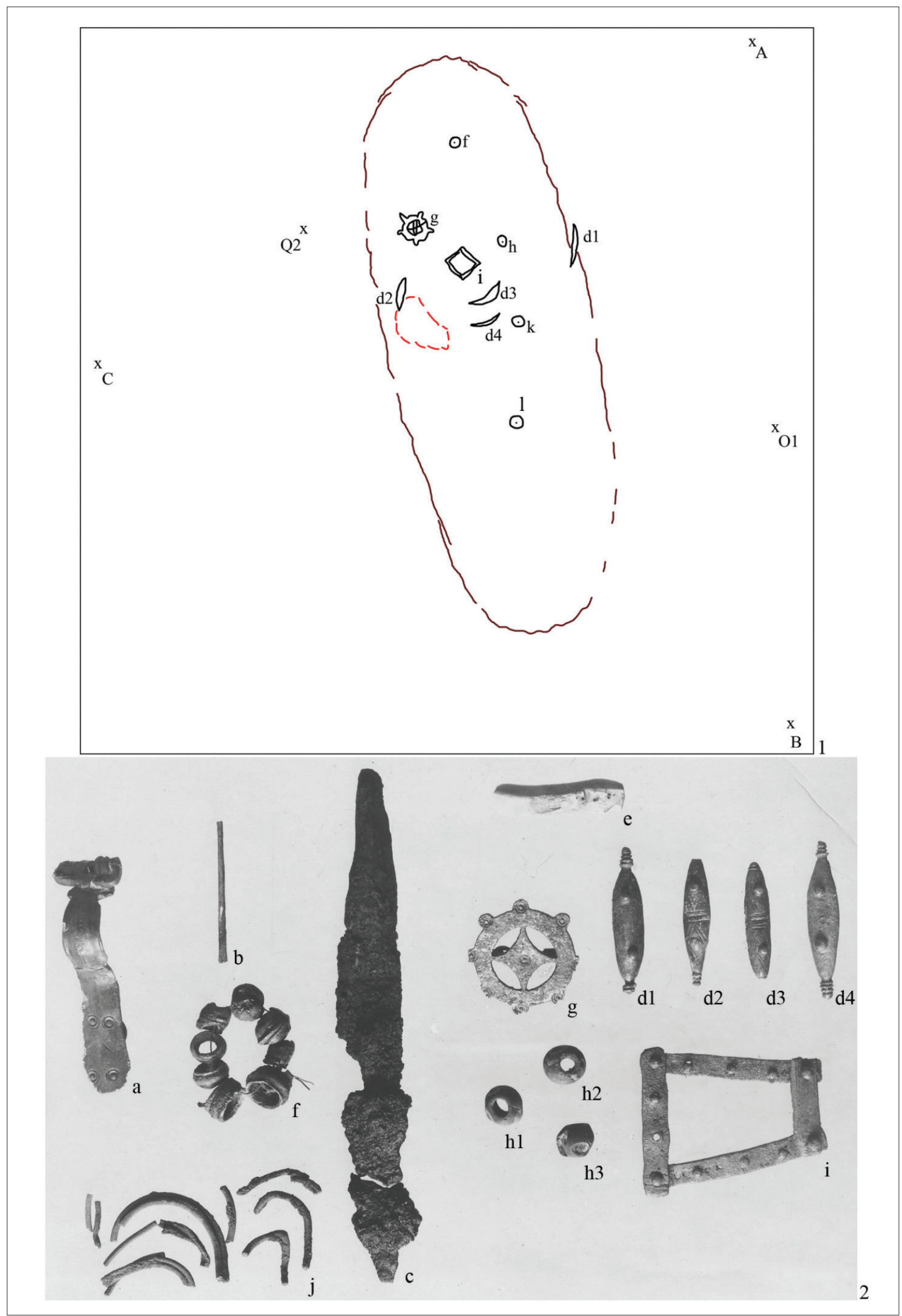

Figure 7. 1. grave 1, the location of grave goods in the pit (d.1-4 belt mounts; g. disc fibula; i. rectangular belt parts; $f, h, k, l$. unidentified objects); 2. a photograph presenting the grave goods found at Perdollen. a fibula from grave 12; d, g, i. finds from grave $1 ; \mathrm{b}, \mathrm{c}$, e-f, h, j. context of the discovery unknown (1 SMB-PK/MVF, PM-IXd8, PM-A 1186/1, compiled by A. Chilińska-Früboes; 2 Grenz archive, book 86). 
Comments: only the grave plan is preserved, without a description. The measurements given in the catalogue were taken from the drawing.

\section{Grave $3(7.8 \mathrm{~m} \mathrm{~N} ; 4.8 \mathrm{~m} \mathrm{~W})^{11}$}

Inhumation grave (?) under a prolonged stone pavement at a depth of 8-10 cm, ca. $150 \mathrm{~cm} \mathrm{NW-SE} \times 60 \mathrm{~cm} \mathrm{SW-}$ NE (Figs. 8.1 and 17); below the stone pavement, the grave pit up to $40 \mathrm{~cm}$ deep, filled with dark brownish earth, surrounded by bright yellow sand; at $20 \mathrm{~cm}$ deep, thick fragments of pottery (marked a - 1).

Inventory: 1) thick pottery fragments.

Chronology: (?).

Collection: Prussia Museum, inv. No unknown; the finds are considered lost.

Sources: SMB-PK/MVF, PM-IXd8, PM-A 1186/1, pp. 12, 23; Grenz archive, book 86.

Comments: no cremated bones and no burnt earth was noticed; that is why the catalogue suggested that the grave might have been an inhumation grave.

\section{Grave 3' (10.2 m S; 85.7 m E)}

Grave pit under a stone pavement at a depth of $20 \mathrm{~cm}, 135$ $\mathrm{cm} \mathrm{NW-SE} \times 85 \mathrm{~cm} \mathrm{NE}-\mathrm{SW}$ (Fig. 8.2); ceiling of the pit at a depth of $80 \mathrm{~cm}, 60 \mathrm{~cm} \mathrm{NS} \times 50 \mathrm{~cm}$ EW; bottom of the pit at a depth of $90 \mathrm{~cm}$; pavement made of big (diameter of 50-70 cm) erratic in shape stones; below the first stone layer and between stones of this layer, some burnt earth; beneath some single stones (Fig. 8.2, marked red) and below, at a depth of $60 \mathrm{~cm}$, three stones (Fig. 8.3), on one of which was lying iron, a very rusted buckle (marked a - 1); in the pit single small stones, some burnt, below the biggest stone (Fig. 8.3 - marked A) a lot of cremated bones, lots of burnt earth and an iron buckle $(2$ - not marked on the plan); above this layer of burnt earth, under the stones in the pit, at a depth of $75 \mathrm{~cm}$, were found: the remains of a bronze buckle (marked b-3), the remains of an iron buckle (marked e -4) and some fragments of pottery (marked c-12); also in the grave were discovered: a small, very destroyed vessel (marked d - 10), found at a depth of $80 \mathrm{~cm}$; a big, flat object ${ }^{12}$ (not marked, 5), and a bronze fitting (marked $\mathrm{f}-6$ ) found at a depth of $85 \mathrm{~cm}$; a spur (7), a large knife (8), and an iron spearhead (marked g - 9), found at a depth of $85 \mathrm{~cm}$, and a vessel on a foot (marked $\mathrm{h}-11$ ), found at a depth of $90 \mathrm{~cm}$.

Inventory: 1) very rusted iron buckle; 2) iron buckle (Eis frühe D-Schnalle); 3) bronze buckle fragment; 4) iron buckle fragment; 5) big flat object; 6) bronze fitting (Bronzenebeschlag), belt part (?); 7) spur; 8) large knife,

\footnotetext{
${ }^{11}$ The catalogue lists the measurements taken by Engel from the point zero (if known).

${ }^{12}$ Description illegible.
}

battle-knife? (Dolchmesser?); 9) iron spearhead; 10) badly destroyed small vessel; 11) vessel on a foot; 12) pottery fragments.

Chronology: D (?).

Collection: Prussia Museum, inv. No unknown; the finds are considered lost.

Sources: SMB-PK/MVF, PM-IXd8, PM-A 1186/1, p. 14; Grenz archive, book 86.

Comments: unfortunately, the grave description given by Engel is not fully legible. Engel also gave two different graves the same number 3 (SMB-PK/MVF, PM-IXd8, PM-A 1186/1, pp. 12, 14, 23). In the catalogue, they are distinguished: one grave kept the number 3 , and the other had an apostrophe added, and is written 3'.

\section{Grave 3a (10.5 m S; $84.9 \mathrm{~m} \mathrm{E})$}

A horse grave (Fig. 8.8) probably originally connected with one of the human graves: 3, 3' or 5 (?); grave pit 180 $\mathrm{cm} \mathrm{NS} \times 65 \mathrm{~cm}$ EW; pit thickness $80 \mathrm{~cm}$ with outwashes at a depth of 70-90 cm; at one end of the pit an iron sickle $(3$ - marked a) and an iron plane $(4$ - marked b), both at an $80 \mathrm{~cm}$ depth; at the other end of the pit an iron bridle (5 - marked d), at $70 \mathrm{~cm}$ depth, and next to it a small iron buckle ( 2 - marked e), at $80 \mathrm{~cm}$ depth; half-way along the pit, by the horse's stomach, a big iron buckle $(\mathbf{1}$ - marked c), at $90 \mathrm{~cm}$ depth.

Inventory: 1) large iron buckle; 2) small iron buckle group ML G; 3) iron sickle; 4) iron plane; 5) iron bridle (Trense).

Chronology: Roman period-Early Migration period.

Collection: Prussia Museum, inv. No unknown; the finds are considered lost.

Sources: SMB-PK/MVF, PM-IXd8, PM-A 1186/1, p. 13; R. Grenz archive, book 86.

6. Grave $4(11.5 \mathrm{~m} \mathrm{~S} ; 83.1 \mathrm{~m} \mathrm{E})$

A grave with three burials (?), an urn burial, an inhumation horse burial, and a pit burial (?), under a small stone pavement at a depth of $20 \mathrm{~cm}$ (Fig. 9.1); the pavement made of single big erratics with diameter of 30-60 $\mathrm{cm}$; between the stones burnt earth; under the stones, at $40 \mathrm{~cm}$ depth, the ceiling of the pit $110 \mathrm{~cm} \mathrm{NW-SE} \times 70$ $\mathrm{cm} \mathrm{NE}-\mathrm{SW}$; the bottom of the pit at $70 \mathrm{~cm}$ depth; grave goods at a depth of 40-60 cm (Fig. 9.2): urn (marked a 1) filled with burnt earth and big fragments of bones of a cremated woman (?) ${ }^{13}$, as well as the following inventory (2-12): a small vessel (2), two fibulae (3-4), an iron fitting (5), two bronze finger-rings (6-7), two melted coloured glass beads (8-9), one melted blue glass bead (10), an iron knife (11), and a clay spindle whorl (12). Moreover, an-

\footnotetext{
${ }^{13}$ According to Engel, these were the bones of a woman. However, no osteological analyses were made.
} 


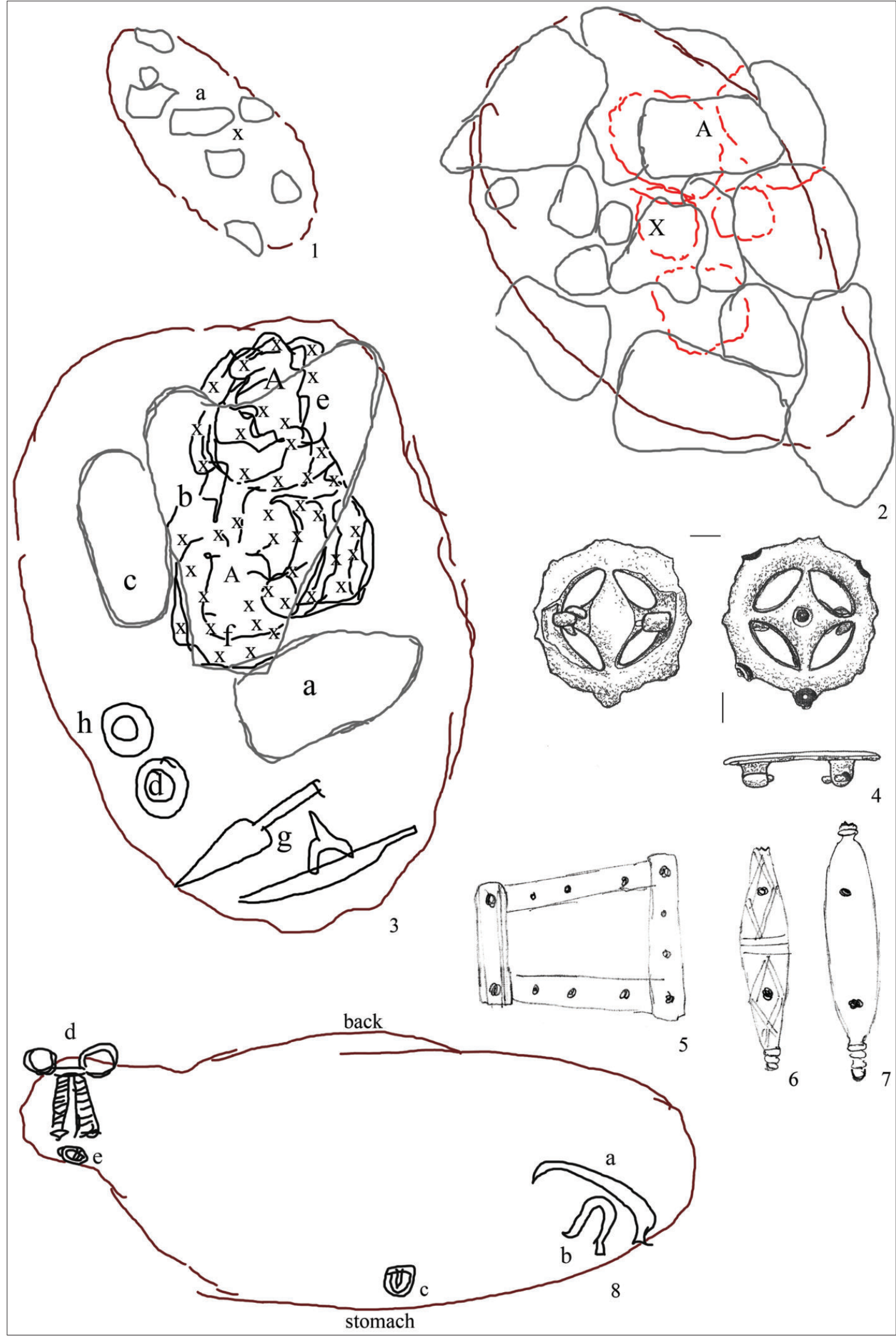

Figure 8. 1. a plan of grave 3 (a pottery fragments). 2-3. plans of grave 3 (A. big stone covering grave pit; a-b, e. buckles; c. pottery fragments; $d$, h. vessels; f. bronze fittings; g. spearhead). 4. the disc fibula from grave 1. 5-7. belt parts from grave 1. 8. a plan of grave 3a (a. sickle; b. plane; c, e. buckle; d. bridle) (1-3, 8 SMB-PK/MVF, PM-IXd8, PM-A 1186/1, compiled by A. ChilińskaFrüboes; 4 drawn by A. Chilińska-Früboes; 5-7 Schmiedehelm archive. 4 scale 1:1. Others no scale). 
other vessel was discovered in the pit: small and reddish (marked b-13), at a depth of $60 \mathrm{~cm}$; a spearhead (marked c-21); an iron fibula (marked d - 14); big and small iron pendants (marked e-f - 16-17); an iron plate (marked $\mathrm{g}$ - 19); a bronze spring (marked $\mathrm{h}-15$ ); a bronze fitting (marked 1-20); an iron buckle (marked $\mathrm{m}$ - 18); an iron shield boss (marked $n-22$ ) filled with the inventory: an iron spur (23), and a bronze belt-end fitting (24). In the western part (of the pit?) visible traces of decomposition: a horse grave (?), here at a depth of $60 \mathrm{~cm}$, an iron buckle (25). In a layer of black earth (the destroyed grave pit?) a shield boss (26) with a shield grip (27), two objects ${ }^{14}$ (28-29), two iron spurs (30-31), a fire-flint (32), an iron spoon (36), two iron handles (37-38), the remains of an iron fitting (34), and below a spearhead (21), an iron firesteel (33) and an iron plate (35).

Inventory: 1) a bucket-shaped urn (Eimerurne); 2) a small vessel of Dollkeim type (Fig. 9.3); 3-4) two bronze crossbow fibulae group A.VI; 5) an iron fitting (Beschlag); 6-7) two bronze finger-rings; 8-9) two melted coloured glass beads (Millefioriperlen); 10) a melted blue glass bead; 11) an iron knife; 12) a clay spindle whorl; 13) a small vessel with a reddish surface; 14) an iron crossbow fibula A.161162 (?); 15) a bronze spring, part of a fibula (?); 16-17) two (?) iron pendants, big and small; 18) an iron buckle group ML G; 19) an iron plate (Beschlagsplatte) a belt part (?); 20) a bronze fitting (Bronzebeschlag), a belt part (?); 21) a spearhead; 22) an iron shield boss; 23) an iron spur; 24) a bronze belt-end fitting; 25) an iron buckle; 26) a shield boss; 27) a shield grip; 28-29) two objects; 30-31) two iron spurs; 32) a fire-flint (Schleifstein); 33) an iron fire-steel; 34) an iron fitting fragment (Rest von Eisenbeschlag), a belt part (?); 35) an iron plate (Beschlagsplatte), a belt part (?); 36) an iron spoon (Löffel), an ear hygiene device (?); 37-38) two iron handles (Fig. 9.4).

Chronology: C1a-b.

Collection: Prussia Museum, inv. No unknown; the finds are considered lost.

Sources: SMB-PK/MVF, PM-IXd8, PM-A 1186/1, pp. 1617; CEAG, pp. 561-562; Grenz archive, book 86.

\section{Grave 5}

A grave with an inhumation human burial and an inhumation horse burial; the human burial was covered with a longitudinal stone pavement made from four layers of stone (Fig. 9.5; the lowest layer marked red); at a depth of $10 \mathrm{~cm}$ a vessel (marked $\mathrm{f}-1$ ); below the fourth layer of stone, at $90 \mathrm{~cm}$ depth, the ceiling of the pit, $180 \mathrm{~cm}$ NNW-SSE $\times 90 \mathrm{~cm}$ WSW-ESE; the bottom of the pit at a depth of $125 \mathrm{~cm}$; in the pit, at a depth of $98 \mathrm{~cm}$, an iron knife (marked $\mathrm{g}-2$ ); at a depth of $100 \mathrm{~cm}$, beads and a needle (marked h-3-4); at a depth of $110 \mathrm{~cm}$, red and

\footnotetext{
${ }^{14}$ Description not fully legible.
}

brown objects (beads? ${ }^{15}-5$ ); next to the human burial, just beside the first layer of the stone pavement, a horse burial (Fig. 9.5, between points $\mathrm{D}-\mathrm{H}$ and point I); in the pit, light grey sand.

Inventory: 1) vessel type Wiekau decorated with circumferential furrows (Fig. 9.6); 2) an iron knife; 3) clay beads; 4) a needle; 5) red and brown objects, beads (?).

Chronology: B2-B2/C1-C1a.

Collection: Prussia Museum, inv. No unknown; the finds are considered lost.

Sources: Engel 1930a; 1930b; 1930c; SMB-PK/MVF, PMIXd8, PM-A 1186/1, p. 19; Grenz archive, book 86.

Comments: the grave description made by Engel (SMBPK/MVF, PM-IXd8, PM-A 1186/1, p. 19) is not fully legible. Engel gave two different graves the same number 5 (SMB-PK/MVF, PM-IXd8, PM-A 1186/1, pp. 18-19). They are distinguished in the catalogue: one grave kept the number 5 , the other had an apostrophe added, and is written 5 ;

\section{Grave 5' $\left(12.10 \mathrm{~m} \mathrm{~S} ; 8[\ldots]^{16} \mathrm{~m} \mathrm{E}\right)$}

The grave pit was covered with two stones; in the middle part of the object, at a depth of $30 \mathrm{~cm}$, a big stone, and in the southern part a small stone; below the stones, at a depth of $50 \mathrm{~cm}$, the ceiling of the pit; the bottom of the pit at $70 \mathrm{~cm}$ depth; on the bottom of the pit a layer of quite thick objects ${ }^{17}$; at the northern edge of the pit: a bronze fibula with the head decorated with silver (1), an iron buckle (2), a bronze buckle (3), an iron belt-end fitting (4), an iron fitting (5), and in the middle (of the pit?), small bronze beads (6).

Inventory: 1) a bronze crossbow fibula with a plate on the head decorated with silver (1 Armbrustfibel bronzene mit silberbelegter Kopfplatte); 2) an iron buckle; 3) a bronze buckle; 4) an iron belt-end fitting; 5) an iron fitting (Beschlagsstück), a belt part (?); 6) small bronze beads.

\section{Chronology: C2 (?).}

Collection: Prussia Museum, inv. No unknown; the finds are considered lost.

Sources: SMB-PK/MVF, PM-IXd8, PM-A 1186/1, p. 18; Grenz archive, book 86.

\section{Grave 6 (14.7 m N; 9 m W)}

Inhumation grave covered with a stone pavement $200 \mathrm{~cm}$ EW $\times 95 \mathrm{~cm} \mathrm{NS}$ (Figs. 9.7 and 18); pavement at a depth of $5 \mathrm{~cm}$; distance between A-B $220 \mathrm{~cm}, \mathrm{~A}-\mathrm{C} 200 \mathrm{~cm}, \mathrm{~B}-\mathrm{C} 95$ $\mathrm{cm}$; below the first stone layer the second layer (marked red), and the ceiling of the oval grave pit, on a NE-SW

\footnotetext{
${ }^{15}$ Not fully legible.

16 The paper is damaged, so the writing is not visible.

${ }^{17}$ Illegible.
} 


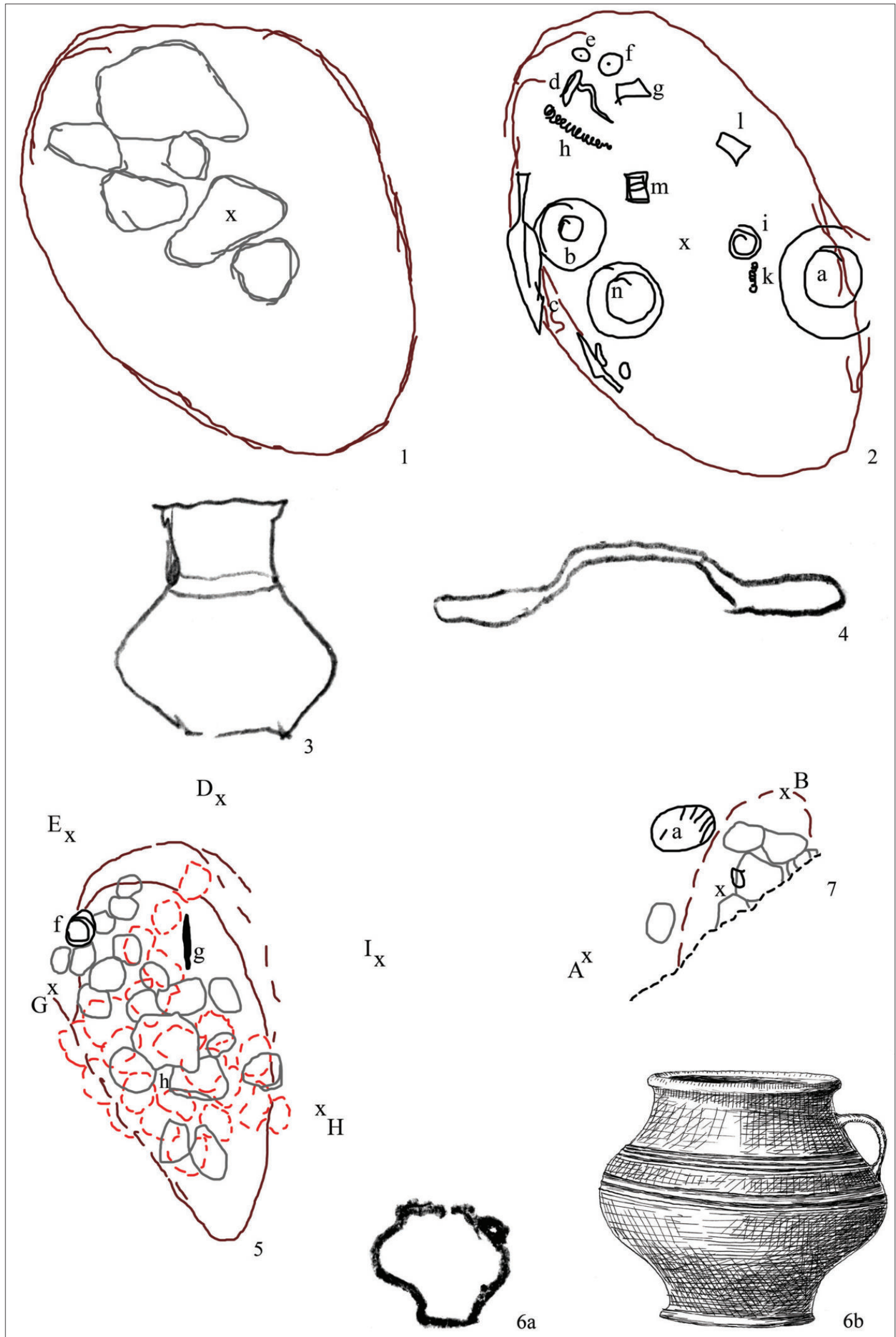

Figure 9. 1-2. plans of grave 4 (a. urn; b. vessel; c. spearhead; d. fibula; e-f. pendants; g. plate; h. spring; i. unknown; l. fitting; m. buckle; $n$. shield boss). 3. a vessel from grave 4. 4. a handle from grave 4. 5. a plan of grave 5 (f. vessel; g. knife; h. beads and needle; D, E, G, H, I measurements points). 6. a vessel from grave 5. 7. a plan of grave 6 (a.unknown; A, B measurements points) (1-5, 6a, 7 SMB-PK/MVF, PM-IXd8, PM-A 1186/1, compiled by A. Chilińska-Früboes; 6b Grenz archive, book 86). 
axis, filled with dark filling. At the shorter end of the pit, an approximately circular object (marked a).

Inventory: (?).

Chronology: (?)

Collection: Prussia Museum, inv. No unknown; the finds are considered lost.

Sources: SMB-PK/MVF, PM-IXd8, PM-A 1186/1, pp. 20, 24; Grenz archive, book. 86.

\section{Grave $7(11.2 \mathrm{~m} \mathrm{~N} ; 11.25 \mathrm{~m} \mathrm{~W})$}

A grave with three (?) burials: an urn human burial (?), an inhumation human burial, and an inhumation horse burial, partly covered with a longitudinal stone pavement of four stone layers (Fig. 10.1 ${ }^{18} ; 18$ ), and surrounded by a stone circle, which was partly destroyed (Fig. 11.1); a pavement at a depth of $10-15 \mathrm{~cm}, 280 \mathrm{~cm} \mathrm{SW-NE} \times 170$ $\mathrm{cm}$ NW-SE; below the first stone layer, at a depth of 40 $\mathrm{cm}$, a few pottery sherds (1) and a lot of big fragments of cremated human bones (an urn burial?); under the pavement, a rectangular pit $240 \mathrm{~cm} \mathrm{SW-NE} \times 180 \mathrm{~cm} \mathrm{NW-SE}$; the bottom of the pit at a depth of $110 \mathrm{~cm}$; in the western part of the pit, a horse inhumation burial; in the eastern part, a human inhumation burial; an inventory belonging to a human burial was deposited in the northeast part of the pit, at a depth of 100-105 cm (Fig. 10.2): a whetstone (marked a - 5), probably a fragment of an iron object (marked b-6), two spurs (both marked c-3-4), a buckle (marked d - 2), a spearhead (marked e -7 ), a socketed axe (marked $\mathrm{f}-\mathbf{8}$ ); south of them, fragments of wood (marked Holzfragm - 9), probably fragments of a coffin; in the western part of the pit, a horse with the head to the south; length of the horse $190 \mathrm{~cm}$ (from teeth to feet), the legs were bent; near the horse were found: at a depth of $105 \mathrm{~cm}$, two objects ${ }^{19}$ (marked g - 13-14) and an iron buckle (marked h-10); at a depth of $80 \mathrm{~cm}$, bronze fittings (marked i - 11); and at a depth of $110 \mathrm{~cm}$, between the horse's teeth, an iron bit with bronze fittings (marked $\mathrm{k}$ - 12); on the horse's head, a decorated brow mount (15) (über der Stirn zierte Bronzeblechbeschlag - see Engel 1930c).

Inventory: 1) a few pottery sherds (urn fragments?); 2) a buckle; 3-4) two iron spurs; 5) a whetstone (Wetzstein - Engel 1930a; 1930b; 1930e; SMB-PK/MVF, PM-IXd8, PM-A $1186 / 1$, p. 25) / rectangular fire flint (vierkant. Feuerschlagstein - Schmiedehelm, archive 7.25.47.182); 6) a fragment of an iron object (?), a fire-steel?; 7) a spearhead; 8) a socketed axe (Tüllenaxt - SMB-PK/MVF, PM-IXd8, PM-A 1186/1, p. 25 / Streitaxt - Engel 1930a; 1930b;

\footnotetext{
${ }^{18}$ The distance A-B $185 \mathrm{~cm}, \mathrm{~B}-\mathrm{C} 175 \mathrm{~cm}, \mathrm{C}-\mathrm{D} 168 \mathrm{~cm}, \mathrm{~B}-\mathrm{D} 160$ $\mathrm{cm}, \mathrm{A}-\mathrm{C} 133 \mathrm{~cm}$.

19 lllegible.
}

1930e; Grenz archive, book 86); 9) fragments of wood, a coffin (?); 10) an iron buckle group ML G (?); 11) bronze fittings (Bronzebeschlag - SMB-PK/MVF, PM-IXd8, PM-A 1186/1, p. 25), harness decorations?; 12) an iron bit with bronze fittings; 13-14) two objects; 15) a bronze decorated brow mount (Nasenberge).

Chronology: B2-B2/C1-C1a.

Collection: Prussia Museum, inv. No VII,172,10458 / VII,262,11634 / VII,367,12455 (?); the finds are considered lost.

Sources: Engel 1930a; 1930b; 1930c; 1935, p. 93; Moora 1938, p. 52; Khomiakova 2016, Fig. 9.5-5a; SMB-PK/ MVF, PM-IXd8, PM-A 1186/1, pp. 21, 24-25; CEAG, p. 561; Grenz archive, book 86; Schmiedehelm, archive 7.25.47.182, 7.25.51.120.

\section{Grave 10}

A grave covered with stones (Fig. 12.1).

Inventory: (?).

Chronology: (?).

Collection: (?).

Sources: Grenz archive, book 86.

Comments: only a photograph of the trench profile with part of the stone construction covering the grave preserved, with no further information.

\section{Grave $A^{20}$}

\section{Description: -}

Inventory: 1) finger-ring similar to type Beckmann 3, with a triangular cross-section (Fig. 12.2); 2-4) three bronze cast bucket-shaped pendants.

\section{Chronology: B2/C1-C1a-D}

Collection: Prussia-Museum, inv. No PM VII,172,10458; the finds are considered lost.

Sources: Schmiedehelm, archive 7.25.51.119.

Comments: the finger-ring and pendants were kept in the Prussia-Museum in one box, which is why Schmiedehelm considered them to be an inventory from one grave. They were probably discovered on 26-27 May 1930, because the finds have the same inv. No as then discovered.

\footnotetext{
${ }^{20}$ Many files concerning graves from Perdollen have survived in archives without grave numbers, however. I have marked these graves in the catalogue with letters (A-L).
} 


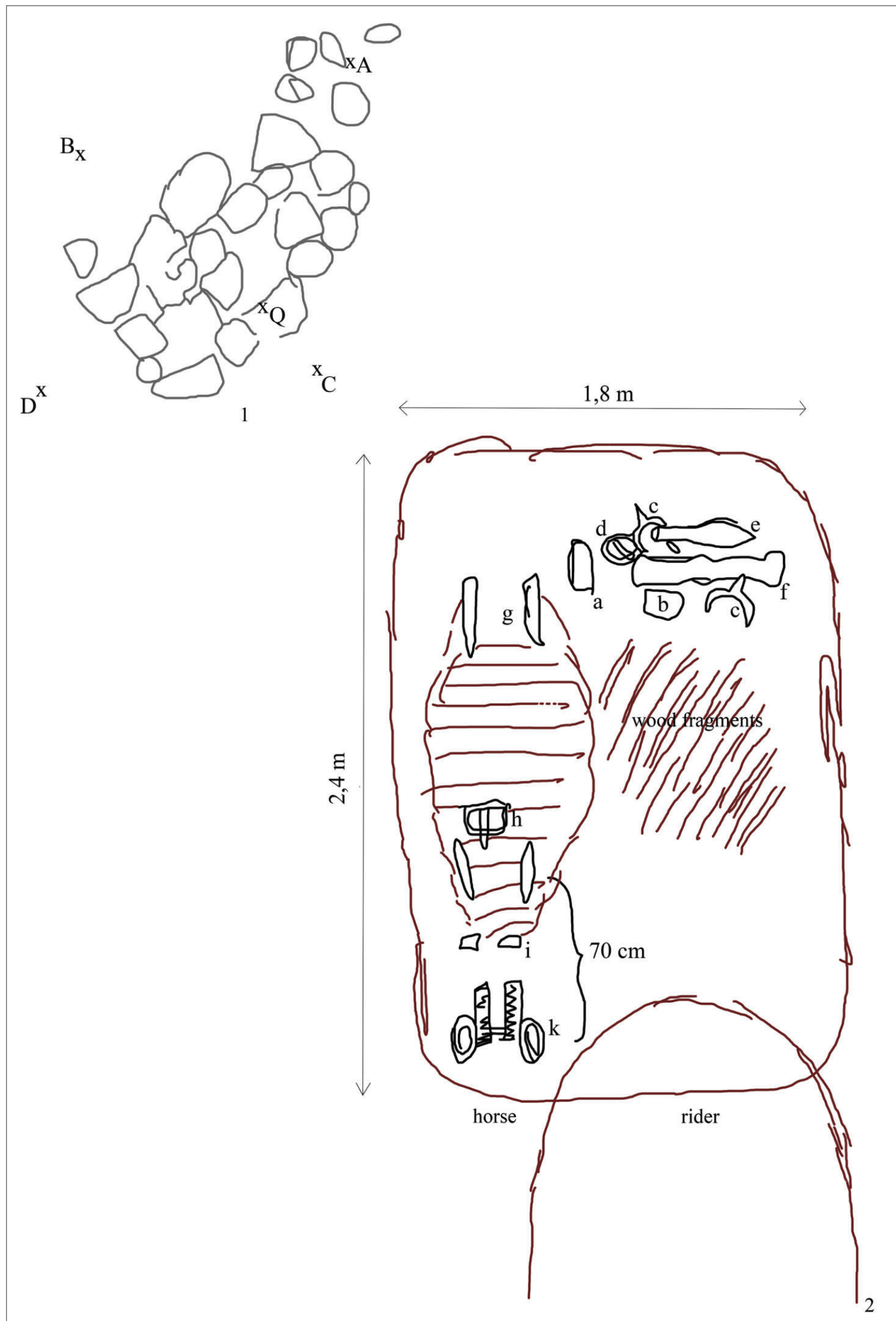

Figure 10. Plans of grave 7 (a whetstone; b iron object (?); c. spurs; d, h. buckles; e. spearhead; f. socketed axe; g. two unknown objects; i. fittings, k. bit with fittings; A-D, Q measurements points) (SMB-PK/MVF, PM-IXd8, PM-A 1186/1, compiled by A. Chilińska-Früboes). 


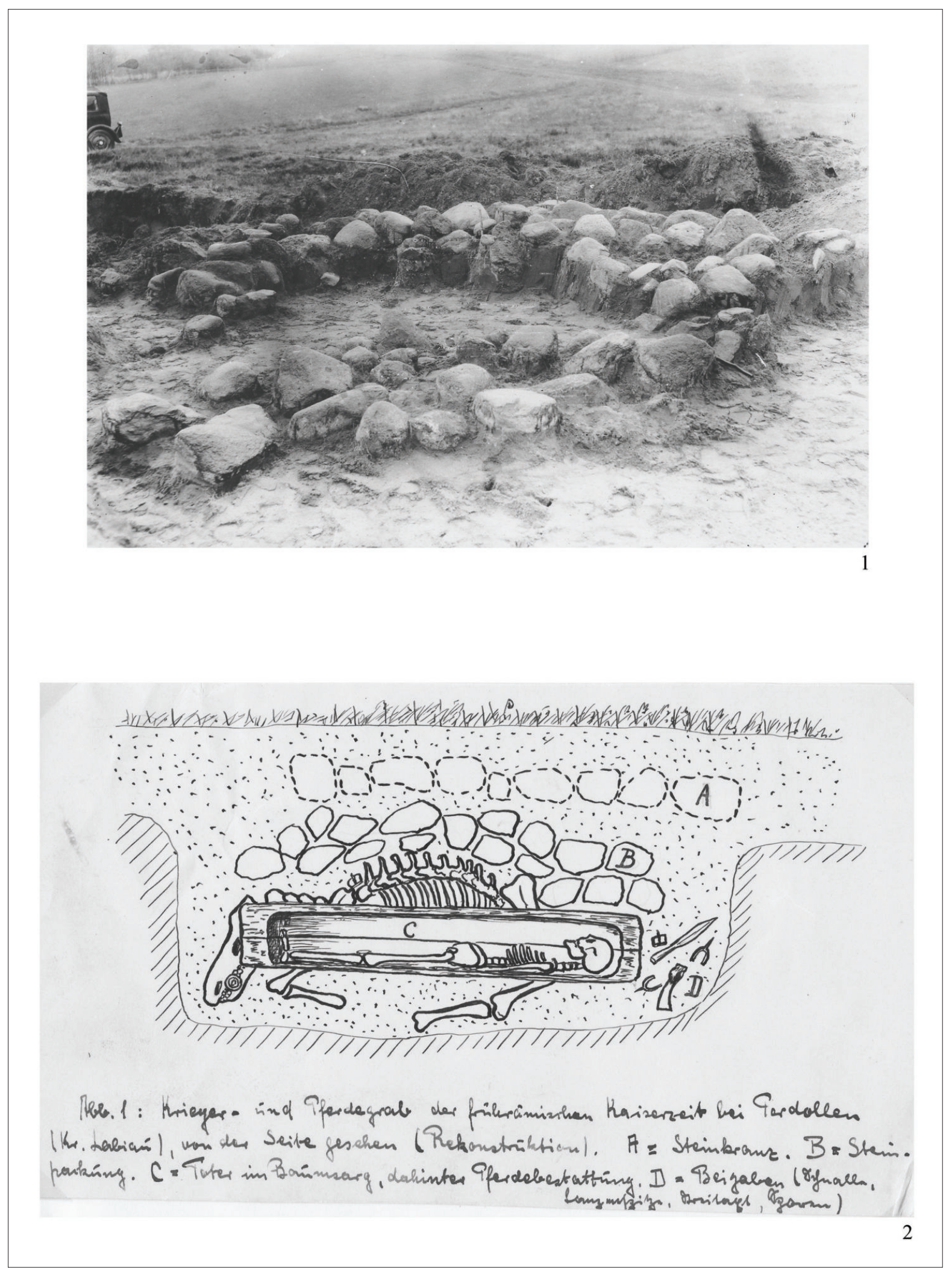

Figure 11. 1. A photograph of grave 7, seen from the southeast, taken on 27 May 1930, with a stone circle visible around the grave; 2. A reconstruction of grave 7, a drawing prepared by Engel for publication (description: Krieger- und Pferdgrab der frühenrömischen Kaiserzeit bei Perdollen [Kr. Labiau], von der Seite gesehen (Rekonstruktion). A = Steinkranz. B = Steinpackung. $C$ - Tote im Baumsarg, dahinter Pferdebestattung. D = Beigaben (Schnalle, Lanzenspitze, Streitaxt, Sporen). Warrior and horse grave from the Early Roman period at Perdollen [Kr. Labiau], side view [reconstruction]. A = stone circle. $\mathrm{B}=$ stone pavement. $\mathrm{C}=$ the deceased in a wooden coffin, behind a horse. $\mathrm{D}=$ grave goods [buckle, spearhead, socketed axe, spurs]) (Grenz archive, book 86). 


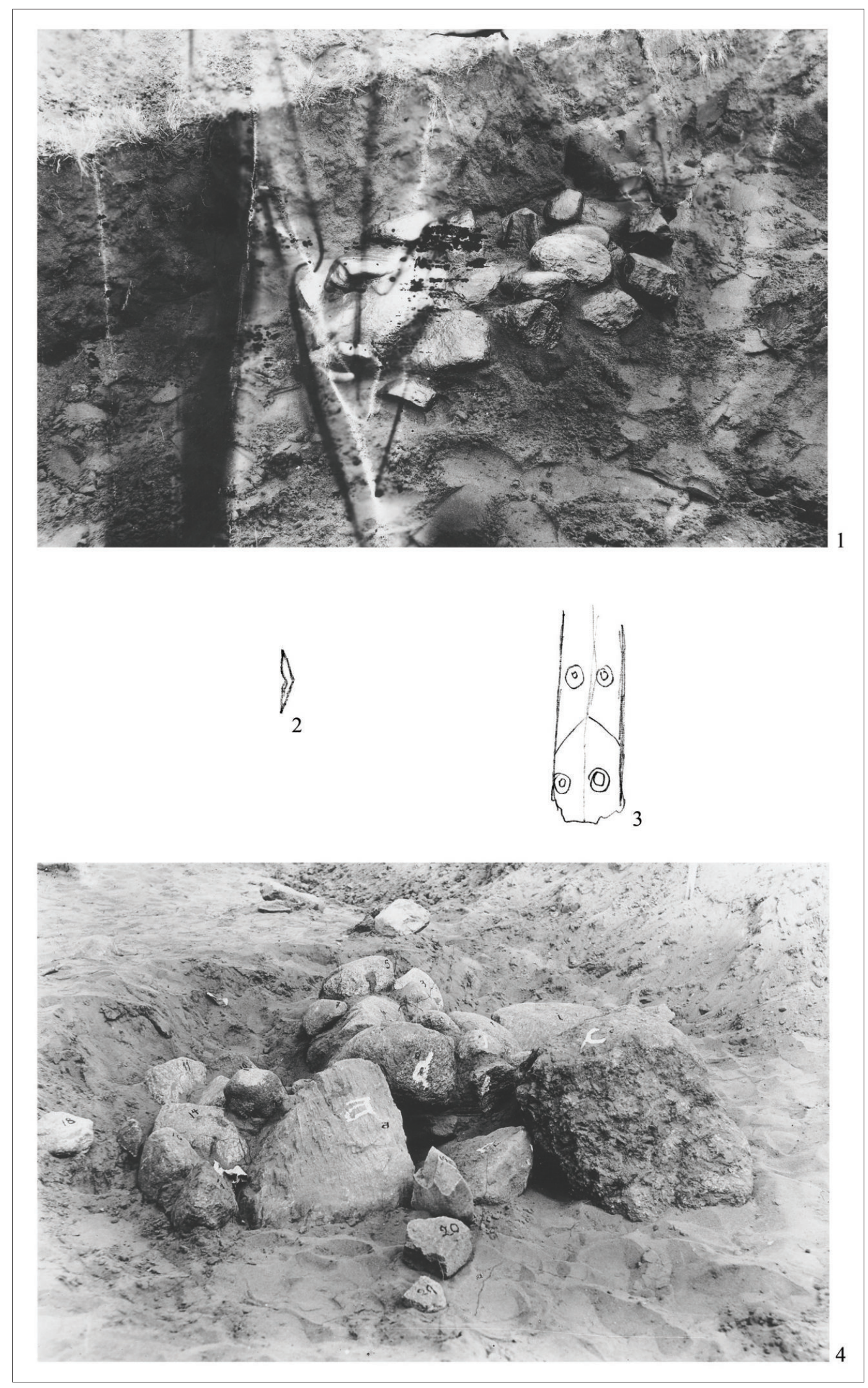

Figure 12. 1. a photograph of grave 10 taken on 27 May 1930, seen from the east. 2. a cross-section of a finger-ring from grave A; 3. a fibula fragment from grave 12; 4. a photograph of grave B taken on 15 July 1930, seen from the south (1, 4 Grenz archive, book 86. 2 Schmiedehelm archive. 3 A. Chilińska-Früboes 2020. No scale). 
V. Excavations carried out by Engel and Fritz Jaensch, 9-10, 14-15 July 1930 21

\section{Grave 12}

Inhumation grave; a skeleton in a wooden coffin.

Inventory: 1) bronze fibula type A.58/59 (Figs. 7.2a and 12.3); on the bow, three pseudo-filigree rows; on the foot, four pairs of concentric embossed circles and engraved diagonal lines.

Chronology: B2a.

Collection: Prussia-Museum, inv. No PM VII,262,11634a; the find is considered lost.

Sources: Engel 1930d; 1930e; Chilińska-Früboes 2017, p. 70, Plate 3.6; 2020, p. 115, Plate 293.1; Grenz archive, box described as Grenz-Archive-Photographs + Negative; Schmiedehelm, archive 7.13.107, 7.25.47.182, 7.25.51.121; SMB-PK/MVF, PM-IXB, PM-F, photograph 000191.

Comments: cat. IV/1.

\section{Grave 13}

An urn grave (?); a few vessels (1) from one chronological period were discovered in a stone chest made of flat stones (Steinplattenkiste), ca. 1 sq. m. and $75 \mathrm{~cm}$ high.

Inventory: 1) a few ton vessels.

Chronology: (?).

Collection: Prussia-Museum, inv. No unknown; the finds are considered lost.

Sources: Moora 1938, p. 52; Grenz archive, book 86.

\section{Grave 15}

An urn grave surrounded by a stone circle with a diameter of ca. $250 \mathrm{~cm}$.

Inventory: (?).

Chronology: B.

Collection: (?)

Sources: Moora 1938, p. 52; Grenz archive, book 86.

Comments: chronology was provided by Engel.

\section{Grave 16}

Inhumation grave surrounded by a stone circle.

Inventory: (?).

\footnotetext{
${ }^{21}$ It is unclear how many graves were excavated in May and how many in July 1930. However, information from the archives shows that grave 10 was definitely still being explored in May. Judging by the inventory numbers, the items from grave 12 were inventoried in the Prussia-Museum at a different time to the items discovered in May. Therefore, the catalogue assumes that grave 12 and graves with later numbers were explored not in May, but in July 1930
}

Chronology: (?).

Collection: (?).

Sources: Moora 1938, p. 52; Grenz archive, book 86.

\section{Grave B}

A grave covered with stones (Fig. 12.4).

Inventory: (?).

Chronology: (?).

Collection: (?).

Sources: Grenz archive, book 86.

Comments: in archives, only a photograph of the stone construction covering the grave is preserved, with a description (Steinkiste von Grab? Von Süden gesehen, geöffnet. 15.7.1930) and no further information. Letters were painted on the stones in situ (visible a-f), and Engel later marked the stones with ink on the photograph with numbers (visible $3-7,10-11,14,18-21$ ), and again with letters $(\mathrm{a}-\mathrm{f})$.

\section{Grave C}

Grave pit in a stone chest (Fig. 13.1-2).

Inventory: (?).

Chronology: B (?).

Collection: (?).

Sources: Grenz archive, book 86.

Comments: in the archives, a preserved photograph of the stone construction covering the grave (Fig. 13.1), with no further information. However, Engel suggested that the grave was probably from the Early Roman period (vermutlich der B-Periode). In the same archive, there is a photograph showing the place where the stone chest was located (Fig. 13.2). It was dismantled, and the place where it had stood was marked with branches. Since not many graves with stone chests have been discovered at Perdollen (graves 13, C, G), the catalogue assumed that the photograph presented the same grave as the grave mentioned before. It should be emphasised, however, that Engel himself was not sure of the grave numbers, and put question marks in the descriptions of all the photographs.

\section{Grave D}

A grave covered with a stone pavement of a minimum of two stone layers; the second layer longitudinal, on an EW axis (Fig. 14.1).

Inventory: (?).

Chronology: (?).

Collection: (?).

Sources: Grenz archive, book 86. 


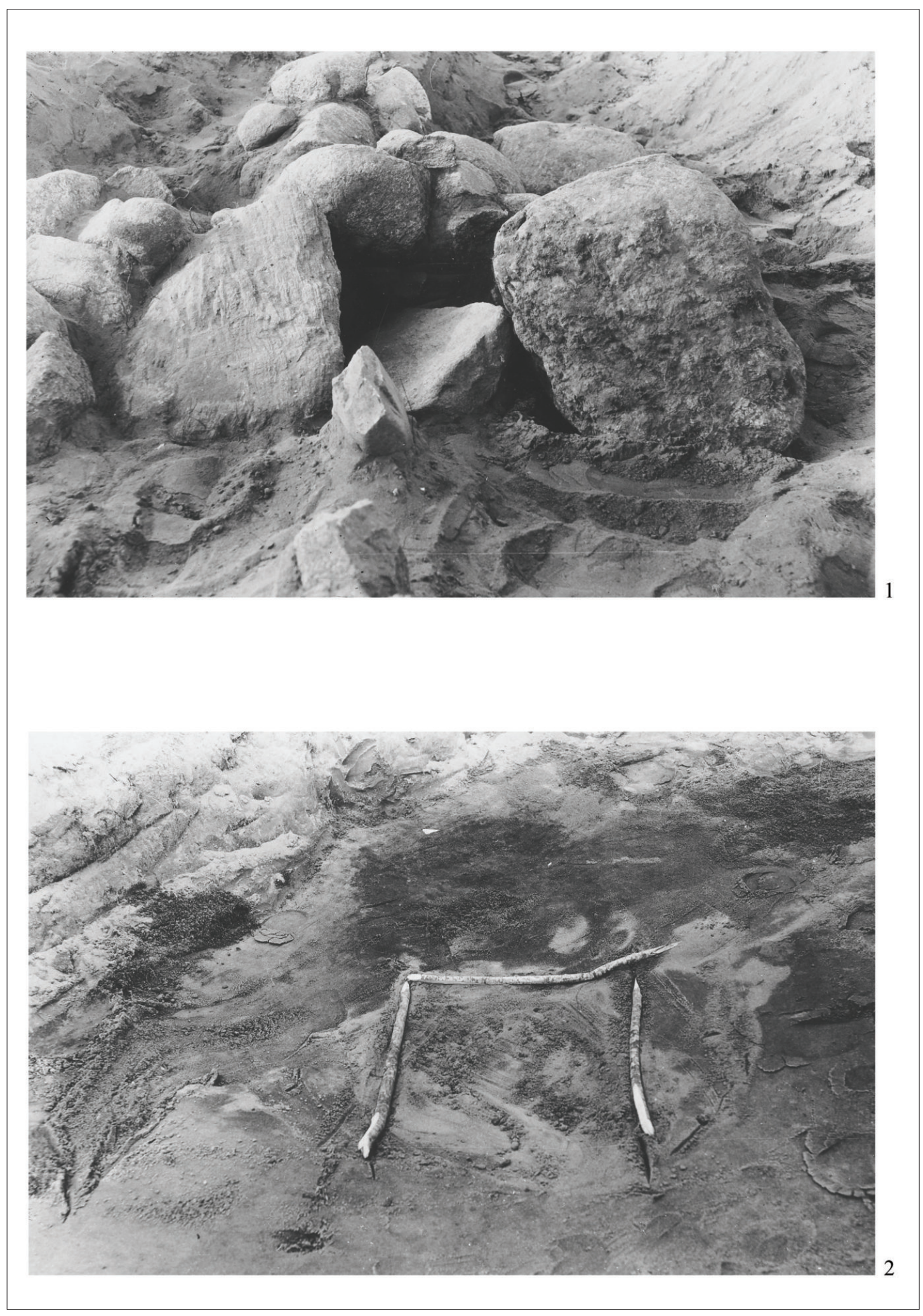

Figure 13. Photographs of grave C taken on 15 July 1930, seen from the northeast (Grenz archive, book 86). 


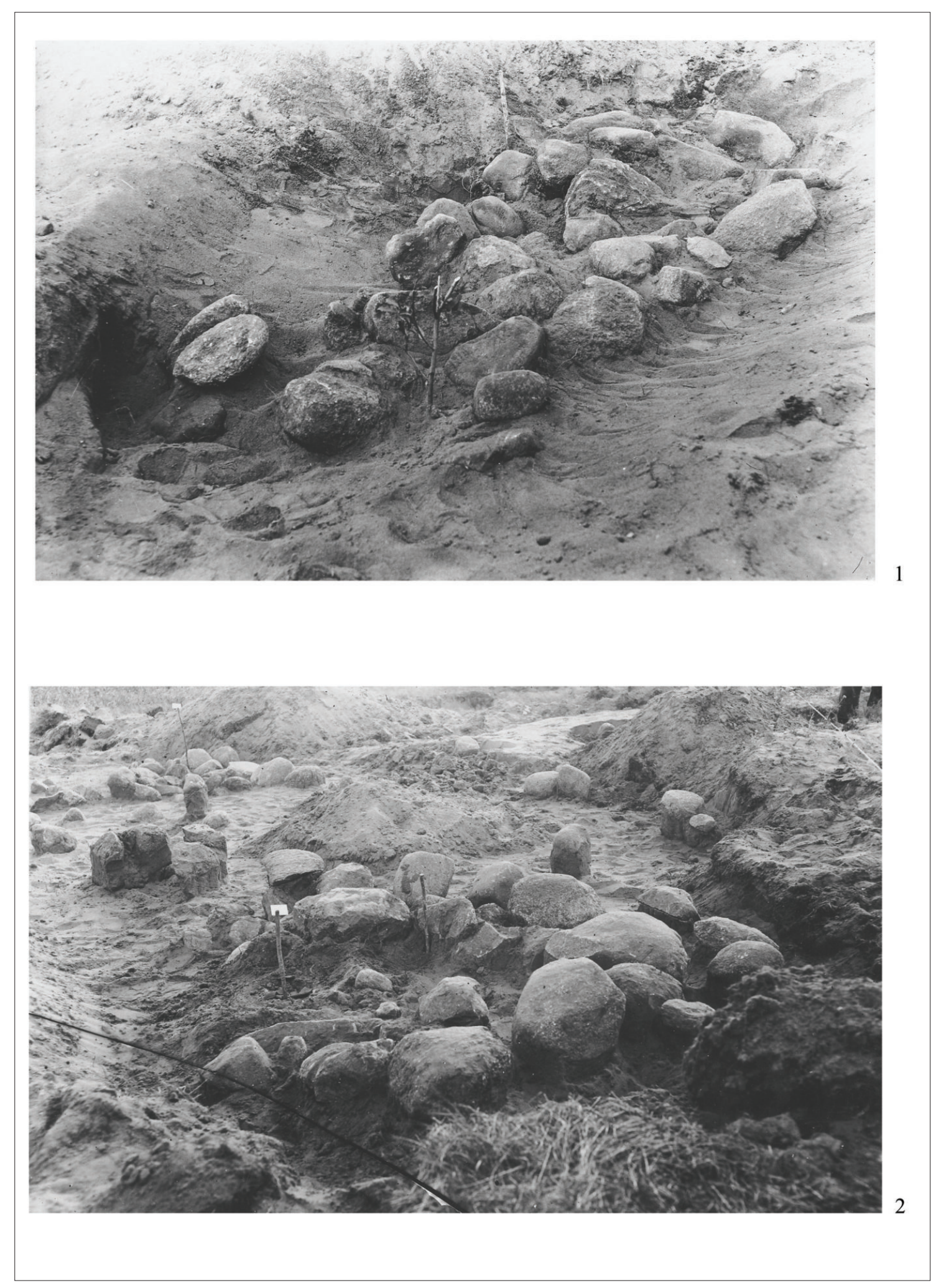

Figure 14. 1. A photograph of grave D taken on 15 July 1930, seen from the northeast. 2. a photograph of grave E taken on 15 July 1930 , seen from the northeast (Grenz archive, book 86). 
Comments: in the archives, only a photograph of the second stone layer covering the pit has been preserved (Fig. 14.1), with no further information.

\section{Grave E}

An urn grave surrounded by a stone circle (Fig. 14.2); the southwest part of the stone circle is destroyed.

Inventory: (?).

Chronology: (?).

Collection: (?).

Sources: Grenz archive, book 86.

Comments: the place where the urn stood was marked in situ with a stick with a note, which is visible in the photograph.

\section{Grave F}

A grave covered with a stone pavement composed of at least two layers; the highest layer longitudinal (Fig. 15.1); on the left of the grave is an animal pit (Tiergrube).

Inventory: (?).

Chronology: (?).

Collection: (?).

Sources: Grenz archive, book 86.

Comments: in the archives, only a photograph of the highest level of the stone pavement covering the grave is preserved, with no further information.

\section{Grave G}

A grave in a stone chest surrounded by a rectangular stone construction; a big stone on top of the chest (Fig. 15.2).

Inventory: (?).

Chronology: (?).

Collection: (?)

Sources: Grenz archive, book 86.

Comments: the only documentation on the object which is preserved is a photograph of part of the cemetery with this grave visible among other objects. It is possible that it is grave 13 or $\mathrm{C}$, but seen in the top layer, both graves had stone chests. However, it is just as likely to be another object with a stone chest.

\section{Grave $H$}

A grave covered with stones (Fig. 15.3).

Inventory: (?).

Chronology: (?).

Collection: (?).

Sources: Grenz archive, book 86.
Comments: in the archives, only a photograph of the stones covering the grave is preserved, taken from the north, with no further information.

\section{Grave I}

A grave covered with stones (Fig. 16.1).

Inventory: (?).

Chronology: (?).

Collection: (?).

Sources: Grenz archive, book 86.

Comments: the only documentation on the object is a photograph of part of the cemetery, with a stone pavement covering the grave, visible among other objects.

\section{Grave J}

Inhumation grave, a plague victim (?) (Jüngeres Skelett, vermutlich aus einer Pestzeit) or a soldier killed in a modern war; the skeleton is lying on its back, on an EW axis (Fig. 16.2).

Inventory: (?).

Chronology: Modern Age (?).

Collection: (?).

Sources: Grenz archive, book 86.

\section{Grave K}

Inhumation grave, plague victim (?) (Jüngeres Skelett, vermutlich aus einer Pestzeit) or a soldier killed in a modern war; the skeleton is lying on its back, on an EW axis (Fig. 16.3).

Inventory: (?).

Chronology: Modern Age (?).

Collection: (?).

Sources: Grenz archive, book 86.

15. Context unknown - stray find/grave find (?)

Inventory: 1) a bronze bracelet made from a wide band with a destroyed body (Fig. 5.2); the body and terminals ornamented with pseudo-filigree rows.

\section{Chronology: B2/C1-C1a.}

Collection: Prussia-Museum, inv. No PM VII,262,11634a; the find is considered lost.

Sources: Schmiedehelm, archive 7.25.51.121.

Comments: based on the inventory number, the bracelet was found in July 1930.

VI. Excavations carried out by the teacher Grünberg on 19 April 1932 

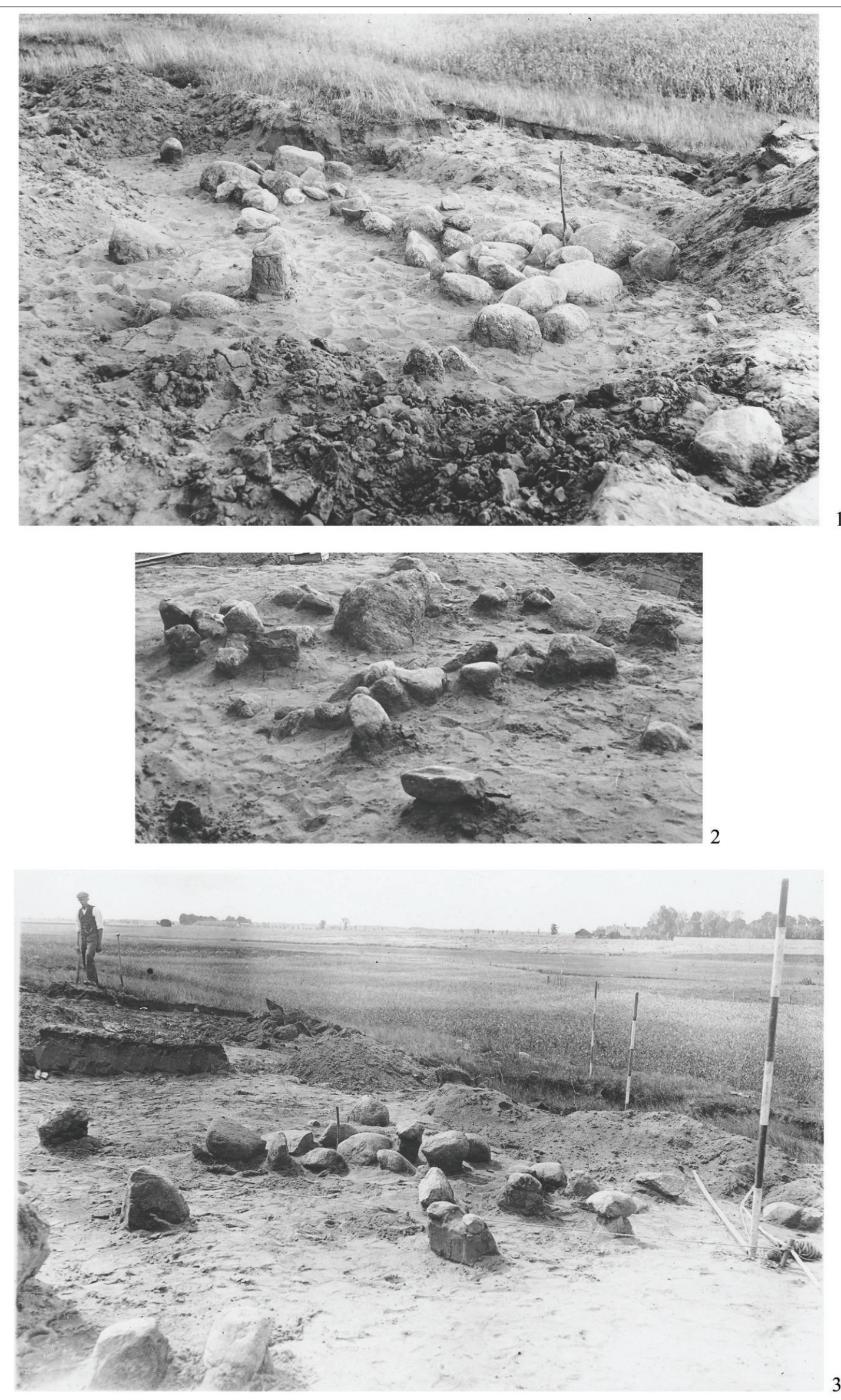

Figure 15. 1. a photograph of grave F taken on 15 July 1930; 2. a photograph of grave G taken on 14 July 1930, seen from the northwest; 3. a photograph of grave $\mathrm{H}$ taken on 14 July 1930, seen from the north (Grenz archive, book 86). 


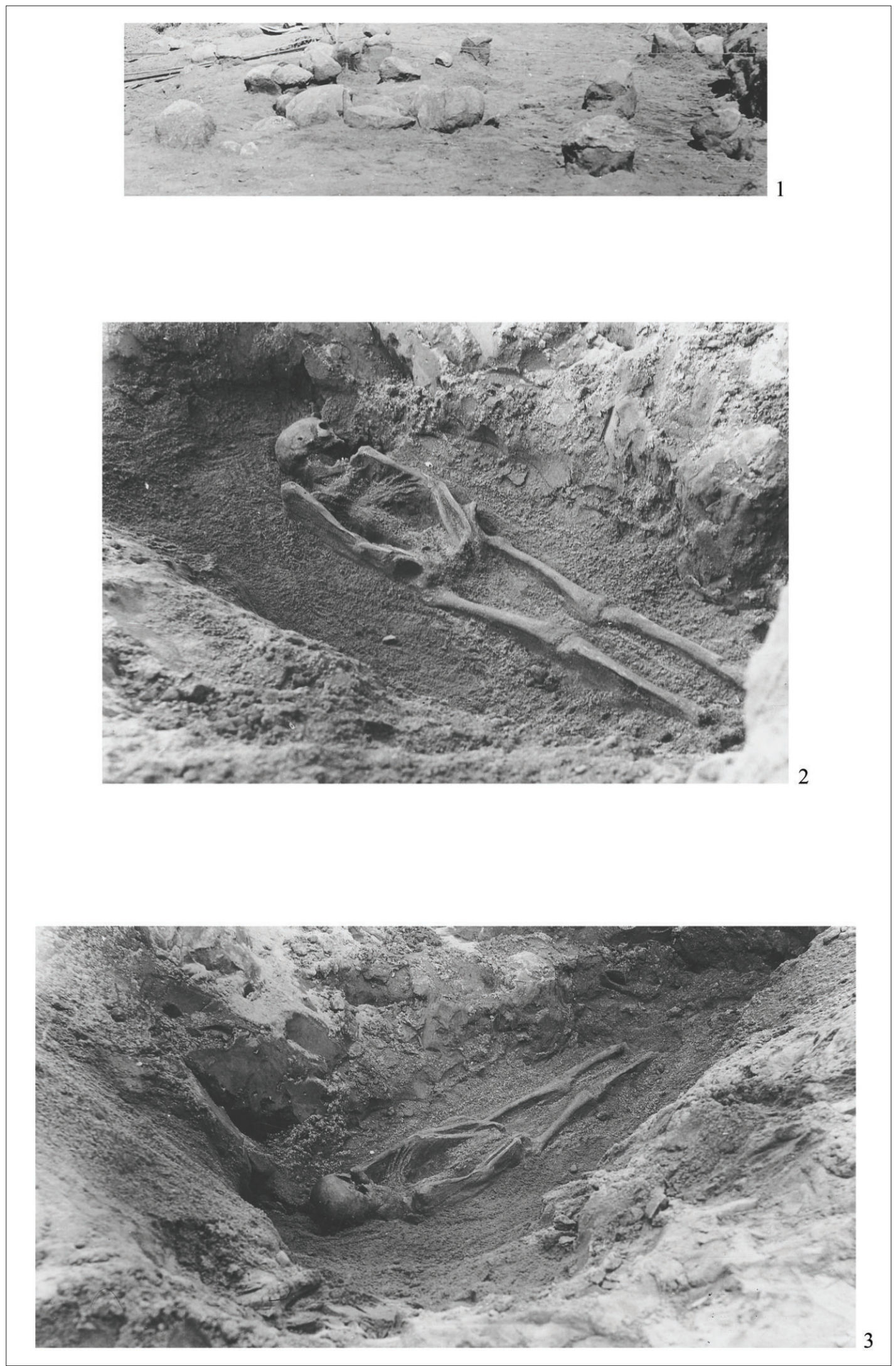

Figure 16. 1. a photograph of grave I, taken on 14 July 1930, seen from the southeast; 2 . a photograph of grave J, seen from the southeast; 3. a photograph of grave K taken on 15 July 1930, seen from the southwest (Grenz archive, book 86). 


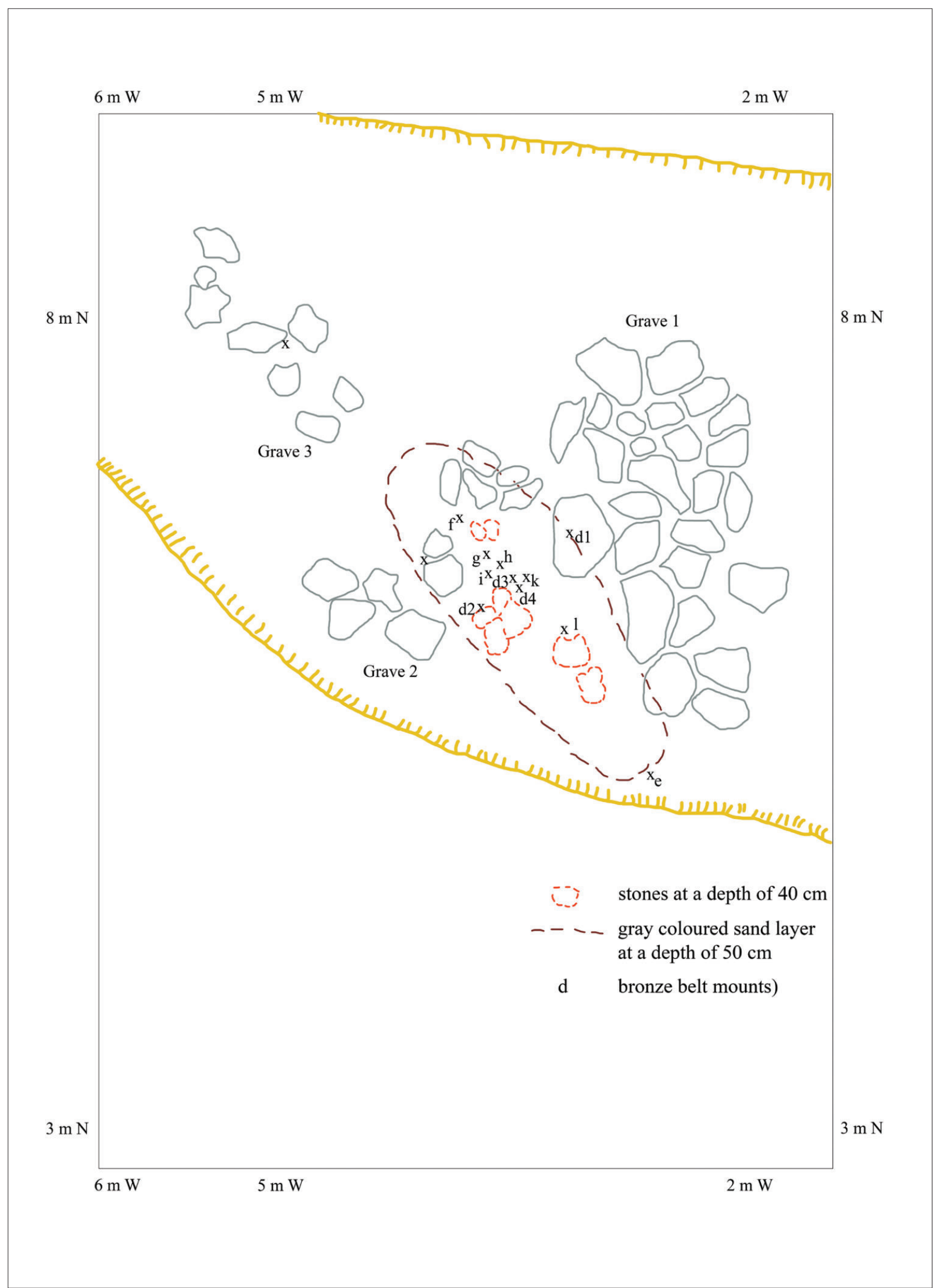

Figure 17. A plan of part of the cemetery at Perdollen, graves 1-3. visible (SMB-PK/MVF, PM-IXd8, PM-A 1186/1, compiled by A. Chilińska-Früboes). 


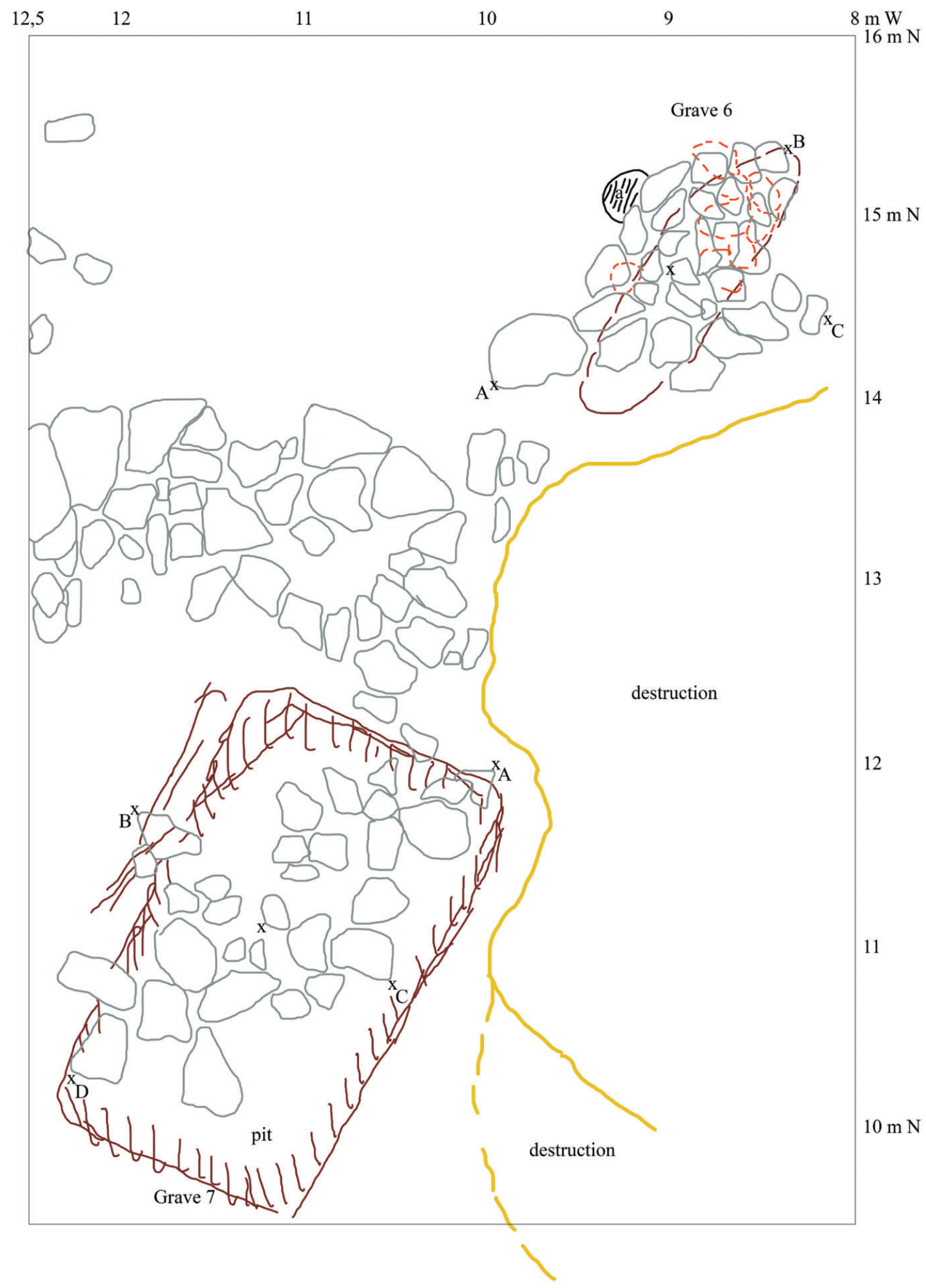

Figure 18. A plan of part of the cemetery at Perdollen, graves 6-7. visible (SMB-PK/MVF, PM-IXd8, PM-A 1186/1, compiled by A. Chilińska-Früboes). 


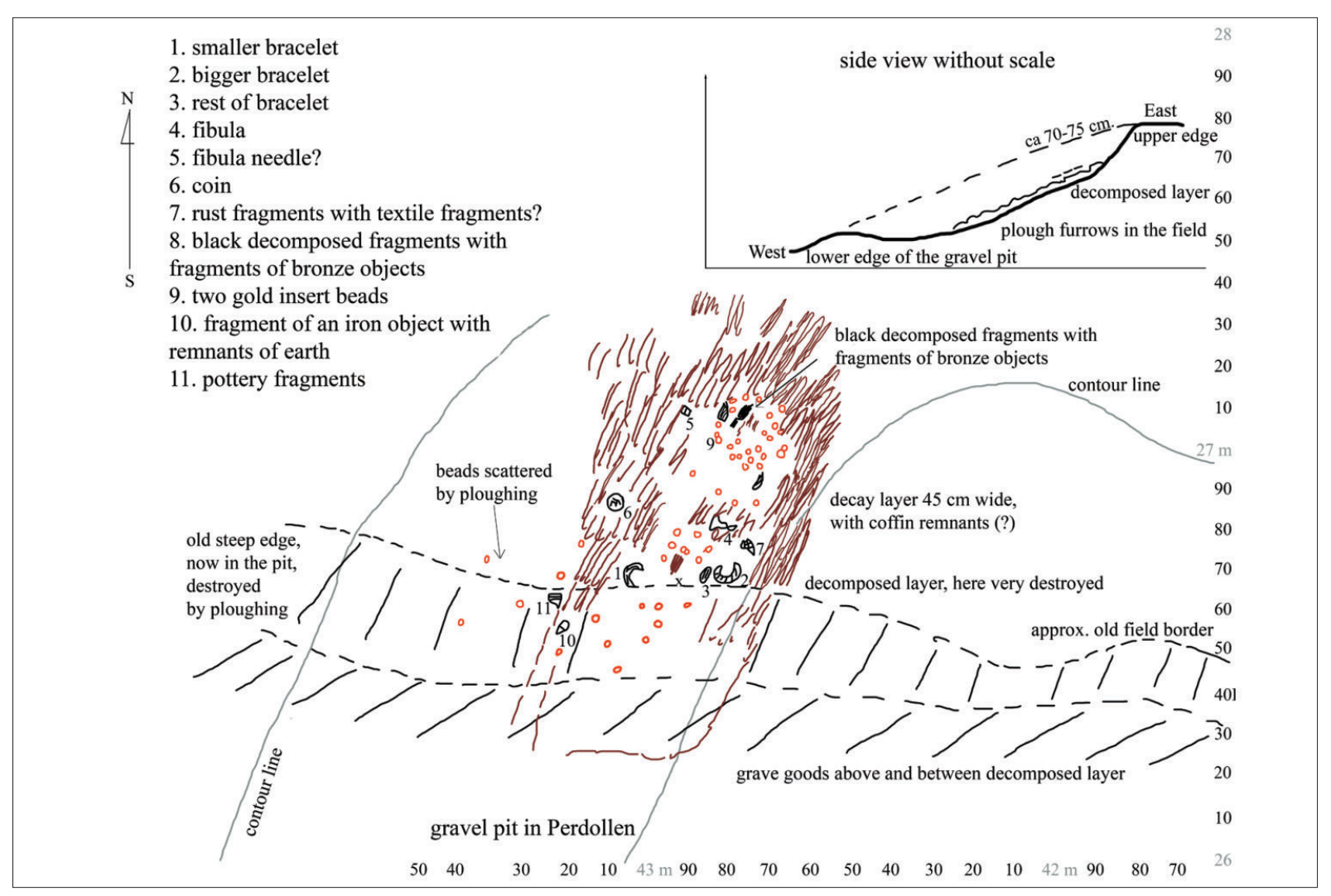

Figure 19. A plan of grave L (SMB-PK/MVF, PM-IXd8, PM-A 1186/1, compiled by A. Chilińska-Früboes).

1. Grave L (18.4 $\mathrm{m}$ from point 0; centre of object $42.9 \mathrm{~m}$ $\mathrm{W}, 26.7 \mathrm{~N})$

A destroyed inhumation grave (no stone constructions were noticed); the northern part of the grave in an arable field, and the southern part in the gravel pit (Fig. 19); the grave pit was probably originally rectangular, badly destroyed by ploughing, especially in the northern part; the preserved part of the pit ca. $90 \mathrm{~cm} \mathrm{NE}-\mathrm{SW} \times 45 \mathrm{~cm}$ NW-SE, with the bottom at a depth of approx. 70-75 $\mathrm{cm}$; by the edges of the pits and to the north of the pit, traces of decomposition with fragments of a weakly decomposed wooden coffin (18 - marked in brown); these decomposition traces were not visible in the southern part of the pit, because the grave was destroyed; skeleton on a NE-SW axis, with the head to the north; in the northern part of the pit (by the head), black decomposed fragments with fragments of bronze objects (15 - verwes. Reste mit Bronzeteilen); slightly to the south, a fragment of a needle (3 - marked 5) and gold foil glass beads ${ }^{22}(\mathbf{8}$ - marked 9); more to the south, half-way along the pit (by the chest?): a coin (14 - marked 6), a fibula (2- marked 4) and fragments of rust with fragments of textile (?) (4 - marked 7), and three bracelets (5-7 - marked 1-3); more to the south, near the western edge of the pit, fragments of a vessel (1 marked 11) and a fragment of an iron object with the remnants of earth (16 - marked 10); goods were discovered

\footnotetext{
${ }^{22}$ All the beads on the plan are marked in red.
}

above and between the layer with traces of decomposition, some were found in ploughing furrows; in all of the pit and by it, a lot of beads (17 - marked in red), pulled out by ploughing, with a concentration in the northern part of the pit, probably previously from one necklace, many were destroyed.

Inventory: 1) fragments of a ton vessel; 2) a bronze fibula A.V.1 - triple-crest brooch of Mazurian variant? (wie Macharren, Urgeschichte 221 S. $221 g^{23}$ - SMB-PK/MVF, PM-IXd8, PM-A 1186/1, p. 65) with crests ornamented with iron inlay (Sprossenf. $m$. Eisenbeleg; Schmiedehelm, archive 7.25.51.122); 3) a fibula needle (?) (Nadel-Pfeilspange? - SMB-PK/MVF, PM-IXd8, PM-A 1186/1, p. $62)$ - fragment of a fibula $(2$ ?); 4) fragments of rust with textile fragments (?) (Roststück m. Geweberesten? - SMBPK/MVF, PM-IXd8, PM-A 1186/1, p. 62) was probably a fragment of a fibula $(2$ ?); 5) a smaller bracelet (Armring, kleiner - SMB-PK/MVF, PM-IXd8, PM-A 1186/1, p. 62) with a wide decorated body (Fig. 5.3) $)^{24}$; 6) a bigger bracelet (Armring, größer - SMB-PK/MVF, PM-IXd8, PM-A 1186/1, p. 62) with a decorated body (Fig. 5.3); 7) half a bracelet with a wide decorated body; 8) three glass beads TM 387; 9) nine red (weinrote - SMB-PK/MVF, PM-IXd8, PM-A 1186/1, p. 65) glass beads; 10) 15 red (ziegelrot - SMB-PK/MVF, PM-IXd8, PM-A 1186/1, p. 65) ton beads; 11) eight blue glass beads; 12) an amber

\footnotetext{
${ }^{23}$ See Gaerte 1929, p. 221, Fig. 167.g.

${ }^{24}$ This drawing concerns three bracelets (5-7).
} 
bead; 13) four bronze beads; 14) a coin of Antoninus Pius; RIC $^{25}$ 623, 140-144; Av.: leg. ANTONINVS AVG PIVS P P TR P COS III; head of Antoninus Pius, laureate, right; Rv.: leg. ROMAE AETERNAE S C; decastyle temple, with statues on the roof and in the pediment, a seated figure in the centre $\left.{ }^{26} ; 15\right)$ black decomposed fragments with pieces of bronze objects, fragments of a cup and adornments for a woman's cap (?); 16) a fragment of an iron object with remnants of earth; 17) many beads; 18) fragments of a wooden coffin.

\section{Chronology: B2/C1-C1a.}

Collection: Prussia-Museum, inv. No PM VII,367,12455; the finds are considered lost.

Sources: SMB-PK/MVF, PM-IXd8, PM-A 1186/1, pp. 60-65; Schmiedehelm archive 7.13d.388, 7.25.47.182, 7.25.51.121, 7.25.51.122.

Comments: according to Grünberg das Roststück mit Geweberesten (4 - SMB-PK/MVF, PM-IXd8, PM-A $1186 / 1$, p. 61), was probably a part of a fibula (2). The number and description of the beads (8-13) are given after Engel (SMB-PK/MVF, PM-IXd8, PM-A 1186/1, p. 65), who saw them at the Prussia-Museum on 27 April 1932. Grünberg noticed a smaller number of beads.

\section{Stray finds discovered on 23 October 1933}

Finds discovered by schoolchildren when, due to the weather conditions, the edges of the gravel pits slipped, revealing graves with stone structures. Some sherds of urn (1) were scattered in the gravel pit, others were in the embankment. Some finds were destroyed by the finders, others were donated to the Prussia-Museum.

\section{Stray finds:}

1) urn sherds; thick and rough shaped; 2) a brick-red fragment of pottery; 3 ) a bright red, smooth pottery fragment; 4) a bronze (!) knife; part of the handle with a piece of leather; destroyed by the finder; L. approx. $4 \mathrm{~cm} ; 5$ ) a button with work through the head.

Chronology: Roman period to Migration period (1-4), and modern times (5) (?).

Collection: Prussia-Museum, inv. No unknown; the finds are considered lost.

Sources: SMB-PK/MVF, PM-IXd8, PM-A 1186/1, p. 2.

\footnotetext{
${ }^{25}$ See Mattingly and Sydenham 1930.

${ }^{26}$ Schmiedehelm (archive 7.25.51.121), describing the coin, referred to the number 699 from Henry Cohen's well-known catalogue (Description historique des monnaies frappées sous l'Empire Romain communément appelées Médailles Impériales). On the basis of Cohen's description, it was possible to determine the RIC number of the coin. I am grateful to Anna Zapolska PhD (Faculty of Archaeology, University of Warsaw) for her help in this study.
}

\section{Analysis}

An analysis of the finds discovered at Perdollen is extremely problematic, because almost all of them (except for one fibula) are lost, and are known only from brief references. Only sporadically are there drawings, or rather sketches, of grave goods, enabling typological or chronological studies.

\section{Fibulae}

Information about seven fibulae from Perdollen has survived. All of them were discovered in a flat cemetery (site II). In grave 12, a fibula type A.58/59 (cat. V/1/1; Figs. 7.2a and 12.3) was found. This type of brooch occurred in the area of Dollkeim-Kovrovo culture in the B2a phase (Chilińska-Früboes 2020, p. 191), and such a chronology should also be applied to the Perdollen specimen.

There are three A.V.1 fibulae known from the cemetery. One of them came from grave L, investigated by Grünberg (cat. VI/1/2), and is known only from a brief mention, in which Engel, while viewing the find in the Prussia-Museum, compared it to a similar fibula from Machary (Machary, pow. mrągowski/Macharren, Kr. Sensburg) (SMB-PK/ MVF, PM-IXd8, PM-A 1186/1, p. 65; cf. Gaerte 1929, Fig. 167.g). The Perdollen fibula was made of bronze, but its crests were covered with iron. A fragment of a needle (cat. $\mathrm{VI} / 1 / 3$ ) was also discovered in the same grave, which was probably part of the aforementioned fibula, and most likely the rust fragments with fragments of textile (cat. VI/1/4) found there also came from the aforementioned brooch. If we trust Engel, and assume that the Perdollen fibula really resembled the one known from Machary, then it would have to be considered a triple-crest brooch of the Masurian variant. These artefacts are characterised by their considerable length, approximately ten to 12 centimetres, with a wide, massive bow and an elongated, narrow leg, bent upwards (Nowakowski 2013, pp. 142-143, with further literature). Such specimens were typical of Bogaczewo culture, but they also appeared in large numbers in the area of Dollkeim-Kovrovo culture (Szter 2010, p. 215). Their chronology falls into phase B2/C1-C1a (Nowakowski 1995, p. 49). The two other triple-crest fibulae known from Perdollen (cat. II/2/1, II/3/1) are stray finds, discovered by the economic officer Iwahn before the cemetery was excavated by Engel. It is known only that they were made of bronze and decorated with iron, their crests were probably ornamented this way. The triple-crest fibulae are among the main artefacts of Dollkeim-Kovrovo culture for phase B2/C1-C1a (Nowakowski 1996, pp. 50-51, Plate 107). The specimens found in this region were usually bronze, decorated with iron inlay ${ }^{27}$ (Schmiedehelm 2011, p. 86), so the findings from Perdollen fit this style.

${ }^{27}$ For example, the former Drusken/Drusker-Forst, Kr. Wehlau (no contemporary name), barrow 5 (Chilińska-Früboes 2020, p. 331, with further literature), Khrustal'noe, district Zeleono- 
There are two bronze crossbow fibulae group A.VI (cat. IV/6/3-4) from grave 4. Unfortunately, they are known only from brief mentions, so it is difficult to analyse them typologically or chronologically. They can only be generally assigned to group A.VI. Both were found in a big bucket-shaped urn (Eimerurne - cat. IV/6/1) containing an inventory indicating a woman's burial, including glass beads, finger-rings and a spindle whorl (cat. IV/6/610.12). An iron crossbow fibula (cat. IV/6/14) was also found in grave 4, but it is also known only from a brief reference. It was most likely a crossbow with a bent foot. Iron fibulae of this type come from the Przeworsk culture area, but they quickly became an inter-regional form, also appearing in large numbers in Dollkeim-Kovrovo culture (Nowakowski 1994, pp. 376-377, Figs. 7 and 8; 2001; Andrzejowski and Cieśliński 2007, pp. 304-305, Fig. 26). It should be admitted, however, that they are not found east of the base of the Curonian Spit (cf. Nowakowski 1994, Fig. 8), and the Perdollen specimen would be one of the finds discovered furthest east in the area of Dollkeim-Kovrovo culture. Most of the iron crossbow brooches known from the West Balt cultural circle can be assigned to types A.161-162, and, like the Perdollen specimen, they are known primarily from brief mentions (Nowakowski 1994, p. 376; 1995, p. 33). In the area of Dollkeim-Kovrovo culture, these artefacts were present mainly in the late part of phase C1a and in phase C1b (Nowakowski 1995, p. 34). This chronology should also be applied to the Perdollen fibula. A piece of a spring (cat. IV/6/15) was discovered in the same grave (4), which may have been part of one of the three brooches found in the grave mentioned above.

A bronze crossbow fibula was discovered in grave 5 ' with a silver decorated plate on the head (Armbrustfibel bronzene mit silberbelegter Kopfplatte - cat. VI/8/1). The description is very brief. At first glance, it might be assumed that it was a rosette-like A.216-217 fibula. Such artefacts are found sporadically in the Dollkeim-Kovrovo culture area (Lund Hansen and Przybyła 2010, p. 265, Figs. 36 and 39), and they belong to group 6 according to Lund Hansen and Przybyła (2010), dated to phases C1b and C2 (Lund

gradsk, Wiekau, Kr. Fischhausen, grave XXXIa (two specimens Jankuhn, archive; cf. Bujack 1889, p. 279), grave XXXVII (two specimens, Chilińska-Früboes 2020, pp. 141-142, Plate 368.34, with further literature) and grave XLI (41) (two specimens, Jankuhn, archive; cf. Bujack 1889, pp. 280-281), Povarovka, Zelenogradsk district/Kirpehnen, Kr. Fischhausen, grave D (Raddatz 1992/1993, Fig. 16,3), Primorskoe-Novoe, Bagrationovsk district/Wollitnick-Fedderau, Kr. Heiligenbeil (two specimens, Skvortsov 2012a, pp. 12-13, Figs. 8.1-2), formerly Rogehnen, Kr. Fischhausen (no contemporary name), grave 102 (Jankuhn, archive), formerly Tengen, Kr. Heiligenbeil (no contemporary name), grave 33 (Klebs 1877, p. 58, Plate II.3), Tiulenino, Polessk district/Viehof, Kr. Labiau, grave 170 (two specimens, Chilińska-Drapella 2010, p. 20, Plate 35.a, with further literature), Ushakovo, Gur'evsk district/Brandenburg, Kr., site 2 (three specimens, Skvortsov 2012a, p. 6, Figs. 4.a.13).
Hansen and Przybyła 2010, p. 270). It seems, however, that if such a fibula had indeed been found at Perdollen, Engel would have pointed it out. Probably a different type of brooch was discovered there: perhaps a crossbow fibula with a bent foot and a plate on the head decorated with silver. Such brooches, additionally decorated with rings of cut wire, were also found in Okunevo, Zelenogradsk district / Grebieten, Kr. Fischhausen, site S, grave 92 (Bujack 1888, p. 245; Jakobson, archive Grebieten070; Schmiedehelm, archive VM 9.21), in former Warengen, Kr. Fischhausen (no contemporary name), stray find (Åberg 1919, pp. 16-17, Fig. 10) and in Orekhovo, Bagrationovsk district/Schuditten, Kr. Fischhausen, stray find (Bezzenberger 1909, p. 44, Fig. 18). Only the specimen from Okunevo comes from a grave, and its chronology falls into the developed Late Roman period, so phase C2 (Szymański 2006, p. 374). This dating should probably also be applied to the Perdollen brooch.

A bronze open-work disc fibula was found in grave 1 (cat. IV/1/1; Figs. 7.2g and 8.4). It is similar to type 24c distinguished by Michel Feugère (1985, pp. 335-336, Fig. 24c), which comprises hinged disc brooches decorated with open-work in the shape of circle segments, with a rhomboid plate in the centre, and usually six projections around the edge. In the centre, type $24 \mathrm{c}$ fibulae have a depression formed by stamped concentric circles filled with glass paste. Finds of such fibulae were concentrated in central and eastern Gaul, Burgundy and western Switzerland. Feugère suspected that the workshop where they were made may have been located in the last of the areas listed, possibly at Augst (Feugère 1985, p. 340, Fig. 50). Outside the western provinces of the Empire, such artefacts have been found over a fairly wide area, including the British Isles, the entirety of France, in Italy and Bulgaria (Feugère 1985, pp. 340, 347-348), and also the area of the West Balts, from where, apart from such fibulae, similar belt mounts or adornments for a woman's cap also came, which are imitations of the provincial brooches discussed (Chilińska-Früboes and Skvortsov, forthcoming). According to Feugère, fibulae type $24 \mathrm{c}$ had not appeared before Claudian times. They were particularly popular during the reign of Claudius and Nero, and can also be sporadically encountered under the rule of the Flavian dynasty; however, finds dating from after the 1st century $\mathrm{AD}$ are rare (Feugère 1985, p. 344). Feugère type 24c corresponds to type 40.1 distinguished by Elisabeth Ettlinger, who dated such brooches to the reign of Claudius (Ettlinger 1973, p. 112, Plate 12.14). Emilie Riha also described identical fibulae, assigning them to type 7.6 that she distinguished (Riha 1979, pp. 183-184, Plate 59.1554-1561), adding that their surface was tinned and the colour of the enamel was unknown; enamel inlays usually fall out, and only concentric, concave circles remain visible in the centre of the brooch. Riha proposed a slightly broader chronology of 
such fibulae than the previous scholars, dating them from the early reign of Claudius up to the 2 nd century AD. The chronology of the Perdollen disc fibula should be determined on the basis of the chronological analysis of the accompanying belt parts ${ }^{28}$ into phases B2/C1-C1a, with the most probable being that it was placed in the grave in phase B2b. This fibula corresponds fully to the forms known from the Roman Empire, and it seems that it is an import (Chilińska-Früboes and Skvortsov forthcoming 2022).

\section{Bracelets}

At least five bracelets were discovered at Perdollen. One of them (cat. II/1/1; Fig. 5.1) was one of the first artefacts to be discovered there. It was a bronze bracelet from quite a wide band (approximately $2 \mathrm{~cm}$ ), with profiled ends and a body decorated with rows of pseudo-filigree, and probably embossed circles. Similar bracelets, but slightly less massive, with more rounded and delicately profiled terminals, were widespread in Dollkeim-Kovrovo culture in $\mathrm{B} 2$ phase, occasionally surviving in B2/C1-C1a phase (Chilińska-Drapella 2010, p. 10, with further literature). The Perdollen specimen, however, has quite massive, square-ended terminals. Such bracelets were typical in phases B2b and B2/C1-C1a. Similar specimens were found in Khrustal'noe, grave XI (two specimens, Bujack 1889, p. 277; Jankuhn archive; Schmiedehelm VM 9.21), grave XXXVII (two specimens, Chilińska-Früboes 2020, pp. 141-142, Plate 368.5) and grave 46 (two specimens, Bujack 1889, p. 276; Jankuhn archive).

During the excavations, Engel discovered another bracelet (cat. V/15/1; Fig. 5.2); unfortunately, the context of its discovery is unknown. It was made from a wide band, and decorated along the bow and across the terminals with pseudo-filigree rows. The teacher Grünberg discovered three nearly identical specimens in grave L, which he investigated (cat. VI/1/5-7; Fig. 5.3). Grünberg's descriptions show that all three were similar, but one was larger, another smaller, and the third was only half-preserved. Artefacts of this type are considered to be one of the determinants of phase B3/C1-C1a of Dollkeim-Kovrovo culture (Nowakowski 1996, Plate 107). This chronology is confirmed by the triple-crest brooch found in grave L (cat. $\mathrm{VI} / 1 / 2)$.

\section{Finger-rings}

At least three finger-rings were found at Perdollen. Two bronze specimens were found in grave 4 (cat. IV/6/6-7). Unfortunately, it is not possible to define them typologically. They come from a grave dated to phases Cla-b, and were found in an urn probably containing a woman's burial. The third Perdollen finger-ring came from grave A

\footnotetext{
${ }^{28}$ See further in the text.
}

(cat. IV/12/1). A drawing of the cross-section of the body has survived (Fig. 12.2), on the basis of which it is possible to assign the ring to Beckmann 3 type with near certainty. These items are not good chronological indicators, and existed throughout almost all the Roman period (Beckmann 1969 , p. 28). However, it cannot be ruled out that the Perdollen finger-ring has a later chronology, maybe it came from the Early Migration period.

\section{Parts of necklaces}

Metal pendants (cat. IV/6/16-17) came from grave 4, probably two, one small and the other large, and they were made of iron. They were lying near other ornaments. It is possible that they were bell-shaped pendants, popular in the area of Dollkeim-Kovrovo culture, mainly in phases C1 and C2 (Woźniak 2013, p. 52, with further literature). The dating of the Perdollen pendants fits into this chronology, because they come from phases $\mathrm{Cla}-\mathrm{b}$. Three bucketshaped pendants were found (cat. IV/12/2-4) in grave A. Items of this type appeared in Dollkeim-Kovrovo culture in phase $\mathrm{B} 2 / \mathrm{C} 1-\mathrm{Cla}$, and were used until phase D (cf. Nowakowski 1996, pp. 50-51, 56-57, Plate 107). Initially, they were stocky and short; with time, they became elongated and slimmer (Chilińska-Früboes 2020, p. 3, with further literature). Since we do not know what the Perdollen bucket-shaped pendants looked like, they should be dated widely, to phases B2/C1-C1a-D.

Beads were discovered in four graves. Most were found in grave L. Unfortunately, the exact number of beads (cat. $\mathrm{VI} / 1 / 8-13.17)$ found is unknown. A necklace discovered there consisted of glass beads in shades of red: nine burgundy (weinrot), and 15 brick-red (ziegelrot). They most likely belonged to TM 12 type, extremely popular in Dollkeim-Kovrovo culture in phases B2 and B2/C1-C1a, although specimens of this type also appeared in phase $\mathrm{C}$ (Chilińska 2009, pp. 97-98, with further literature). However, it cannot be ruled out that the brick-red beads represented TM 10 type, which was rare, but was still found in the area of Dollkeim-Kovrovo culture (TempelmannMączyńska 1985, pp. 330, 337, Plate 22). Apart from these beads, the necklace from grave L included at least eight blue glass beads (it is not possible to determine their typological affiliation), and at least three glass beads with a gold insert, type TM 387; beads of this type were one of the most popular beads in the area of Dollkeim-Kovrovo culture, occurring there from phase B2 to the Early Roman period. However, as early as from phase $\mathrm{B} 2 / \mathrm{C} 1-\mathrm{C} 1 \mathrm{a}$, their popularity in the discussed area decreased visibly (Chilińska 2009, pp. 102-103, with further literature). The necklace from grave $\mathrm{L}$ also included four bronze beads, but there is no information about their shape or possible decoration. The necklace in question was also decorated with one amber bead. In phases B2 and B2/C1-C1a, amber beads only sporadically decorated the necklaces of 
people of Dollkeim-Kovrovo culture. These necklaces usually consisted of several dozen glass and bronze beads, and a single amber bead (Chilińska 2009, p. 104). Amber beads became popular in this area later, in the Early Roman period.

Three melted glass beads (cat. IV/6/8-10) came from grave 4. Two were described as Millefioriperlen, so they had multi-coloured embedded patterns. They could be simple dots, stripes, or more complicated patterns. Unfortunately, it is not possible to define their typological affiliation. One melted blue glass bead accompanied them. Also, in this case, we are dealing only with a short description, which makes typological studies impossible. All three came from phases C1a-b. Several beads were also discovered in grave 5 (their exact number is unknown, and the description is also not accurate). According to Engel, they were made of clay (cat. IV/7/3), perhaps some of them were brown or red (cat. IV/7/5). They are dated to phases B2-B2/C1. Some small bronze beads (cat. IV/8/6) also came from grave 5', probably from phase $\mathrm{C} 2$.

\section{Adornments for a woman's cap (?)}

Black decomposed parts with fragments of bronze objects (cat. VI/1/15) were discovered in grave L near the skull. It is possible that they are the remains of some kind of headdress and its decoration. In phase B2, women of DollkeimKovrovo culture decorated caps or scarves worn on their heads with small bronze adornments, and this custom also continued in phase B2/C1-C1a (Chilińska 2009, pp. 86-88; Chilińska-Früboes 2020, pp. 181-280, 286, with further literature). It is possible that such ornaments were discovered in grave $\mathrm{L}$.

\section{Belt parts}

At least two iron buckles of ML G group came from the cemetery. One was found in grave $3 a$ (cat. IV/5/2), and we only know that it was small. Since it was found near a horse's head, near the bit, it was most likely related to the bridle. A second buckle was found in the same grave: a large, iron buckle of unspecified type (cat. IV/5/1). It was found near the horse's belly, so it probably fastened the harness straps running under the belly or the girth.

A buckle of ML G group also came from grave 4 (cat. IV/6/18). It lay more or less in the centre of the pit, containing probably a woman's burial, a horse burial, and a large amount of weapons, suggesting that a man might also have been buried there. It is difficult to say whether the buckle in question was related to the burial of a horse, or whether it comes from a bridle or was a part of a man's outfit. A second buckle (made of iron) from this grave (cat. $\mathrm{IV} / 6 / 25)$ is also known only from a brief reference, not allowing for typological determination. It was most likely located next to the horse's remains, so it was probably tied to a bridle or a harness. A bronze belt-end fitting of unspecified type was found in the same grave (cat. IV/6/24). It was placed in a shield boss (cat. IV/6/22) together with a spur (cat. IV/6/23), next to weapons. It probably came from a man's belt. Some other grave goods that could have been related to belts also came from this grave: an iron fitting (Beschlag - cat. IV/6/5) found in an urn containing a woman's burial; a fragment of an iron fitting (Rest von Eisenbeschlag - cat. IV/6/34) and an iron plate (Beschlagsplatte - cat. IV/6/35) which were lying in a layer of burnt earth; a square iron plate (Beschlagsplatte - cat. IV/6/19); and a bronze fitting (Bronzebeschlag - cat. IV/6/20).

As many as four buckles were found in grave 3' (cat. IV/4/1-4); some were partly preserved. One, made of iron, heavily corroded, lay on a large stone. Another, made of iron, was found under the stone, in a cluster of burnt bones. Engel described it as (Eis frühe D-Schnalle - SMBPK/MVF, PM-IXd8, PM-A 1186/1, p. 14), so it can be assumed that it was a buckle dating from the Early Migration period. A little higher in the grave, there were fragments of bronze and iron buckles. Grave 3' was a grave pit, which, due to the presence of weapons, should most likely be considered a man's burial. Certainly not all buckles found there were used to fasten a waist belt. It is likely that at least one of them spanned a balteus, maybe for hanging a battle-knife (cat. IV/4/8). However, these are only hypothetical considerations. Moreover, a bronze fitting came from the same grave (Bronzenebeschlag - cat. IV/4/6). It is possible that it was also associated with a belt.

Two buckles discovered in grave 5' are only known from short mentions (cat. IV/8/2-3). It is known that one was made of iron, the other was made of bronze. An iron beltend fitting (cat. IV/8/4) was also discovered in the same grave, most likely from the same belt as the iron buckle, and an iron fitting (Beschlagsstück - cat. IV/8/5), probably also from a belt. All these grave goods are probably from phase C2.

A pair of buckles was also found in grave 7. One of them (cat. IV/10/2) was found among an inventory belonging to a man's grave, so it can be assumed that it originally fastened a waist belt. The second iron buckle, maybe group ML G (cat. IV/10/10), was found among the remains of a horse, probably near the belly, so it might have been fastened with a harness or a girth. Both are dated to phases B2 to B2/C1-C1a.

In grave 1 , four belt mounts (cat. IV/1/2-3) were discovered similar to type Garbsch Ka, with boat-shaped bodies and narrow, profiled terminals (Figs. 7.2d1-4 and 8.6-7). Artefacts of this type in the area of Dollkeim-Kovrovo culture were usually part of 'Samland belts'. These belts are dated to phases $\mathrm{B} 2 \mathrm{a}-\mathrm{B} 2 / \mathrm{C} 1-\mathrm{C} 1 \mathrm{a}$, but were most prevalent 
in phase $\mathrm{B}_{2} \mathrm{~b}^{29}$ (Chilińska-Drapella 2010, p. 10). Such a broad chronology should also be applied to the Perdollen mounts. Moreover, the grave yielded a fitting (cat. IV/1/4) composed of four plates connected by four rivets with large hemispherical heads and studded with eight more specimens with smaller heads (Figs. 7.2i and 8.5). It is probably a belt part: a belt mount or a buckle/clasp fragment. Similar artefacts (made of iron) can be found in the Pisanski collection housed in the MVF (Nowakowski 1998, pp. 75, 129, Fig. 25.711-712, Plate 33.711-712). Nowakowski dates them to phase B2, based on a rather distant analogy with the 'Samlands belts' present during this period. An artefact from the collection of the former Königliches Staatsarchiv in Königsberg, a Krempenschnalle (a buckle similar to types ML F2-3) with an iron attachment plate made of six riveted plates (Chilińska-Drapella 2010, p. 7, Plate 27.e - with further literature), is a slightly more distant analogy of the Perdollen find. However, neither this artefact nor the specimens from the Pisanski collection can be dated with certainty.

\section{Weapons}

Two shield bosses were discovered in grave 4 dated to C1a-b phase. One (cat. IV/6/22) was filled with a spur (cat. IV/6/23) and a belt-end fitting (cat. IV/6/24). It was lying at the edge of the pit. The second shield boss (cat. IV/6/26), along with a shield grip (cat. IV/6/27), was lying in burnt earth, next to spurs and tools. Therefore, there must have originally been at least two shields in grave 4 .

Single spearheads were discovered in three graves. One came from grave 3' (cat. IV/4/9), probably dated to phase D. Another was found in grave 4 (cat. IV/6/21), dated to phases C1a-b. A third was found in grave 7 (cat. IV/10/7), from phases B2-B2/C1-C1a.

Six spurs came from Perdollen. One was found in grave 3' (cat. IV/10/7). Unfortunately, it is known from only a brief mention, which makes it impossible to define its typology, but its chronology probably falls in phase $\mathrm{D}$. As many as three spurs came from grave 4 . One of them (cat. IV/6/23) was lying in a shield boss (cat. IV/6/22), with a belt-end fitting (cat. IV/6/24). The other two spurs in grave 4 (cat. IV/6/30-31) lay in a different part of the pit, in a layer of burnt earth, with weapons. They most likely came from someone else's outfit than the spur lying in the shield boss. They all come from phases $\mathrm{C} 1 \mathrm{a}-\mathrm{b}$. A pair of spurs was also found in grave 7 (cat. IV/10/3-4). Unfortunately, these two are also only known from a brief mention. They were

${ }_{29}$ Belt mounts dated to phase B2a, e.g. Kovrovo, Zelenogradsk district/Dollkeim, Kr. Fischhausen, grave 9 (ChilińskaFrüboes 2020, pp. 57-58, Plate 82.17); to phase B2b (when they were most popular), e.g. Kovrovo, grave 30 (ChilińskaFrüboes 2020, pp. 70-71, Plate 139.12); phase B2/C1-C1a (when they were rare), e.g. Berezovka, Gvardejsk district/ Groß Ottenhagen, Kr. Königsberg, grave 19 (Ibsen and Skvorzov 2005, Fig. 19). lying next to the man's head, among weapons. Their chronology can only be defined as phases B2-B2/C1-C1a.

A large knife was discovered in grave 3' (cat. IV/4/8), probably dated to phase D. It can be assumed that it was almost certainly a battle-knife (Dolchmesser). Such knives were used in combat, and were widespread in the area of Dollkeim-Kovrovo culture, where they appeared in phase C3, and were in use until phase D3 or even phase E1 (Prassolow 2018, p. 105).

\section{Tools}

Three knives came from Perdollen that were probably tools, and not weapons. One, from phases $\mathrm{Cla}-\mathrm{b}$, was found in grave 4 (cat. IV/6/11). It was placed in an urn (cat. IV/6/1) probably containing a woman's burial. The second knife was found in grave 5 (cat. IV/7/2), and its chronology falls in phases B2 - B2/C1-C1a. The third knife is a stray find, found by schoolchildren when the gravel pit caved in (cat. VII/4). The artefact was destroyed by the finder, but the description shows that it was bronze (!), and that part of the handle was covered with leather. It is difficult to be sure that there is no mistake in the description, as knives are almost always made of iron. However, an iron knife was found in Putilovo, Zelenogradsk district/Corjeiten/ Korjeiten, Kr. Fischhausen, grave 15, described in archival sources as having a bronze handle; but it seems that in this case only a fragment of a bronze object was attached to the handle (Chilińska-Drapella 2010, pp. 12, 29). Iron knives, however, might have had some bronze elements, e.g. rivets fixing the cladding to the handle, or they could have been decorated with bronze inlay (Chilińska 2009, pp. 119-120).

A socket axe (cat. IV/10/8) probably came from grave 7 . Engel referred to it in the field documentation as Tüllenaxt (SMB-PK/MVF, PM-IXd8, PM-A 1186/1, p. 25), and in the published popular science articles on the Perdollen material, he called it Streitaxt (Engel 1930a; 1930b; 1930c), which might suggest that we are dealing with a battle-axe. It seems, however, that Engel wanted to use a term in the press that was understandable to a wide audience, and in fact it was a socket axe. Moreover, battle-axes are relatively rare finds in the area of Dollkeim-Kovrovo culture, and it should be assumed that Engel would have drawn attention to such a discovery. Socket axes were widespread in the area of Dollkeim-Kovrovo culture (Kontny 2016, pp. 49, 52). So far, no detailed chronological studies of them have been carried out, but the oldest specimens appeared in phase B2a (e.g. Kovrovo, grave 7, Chilińska-Früboes 2020, pp. 56-57, 292, Plate. 76.15), and these artefacts were extremely popular throughout the Early Roman period (Nowakowski 1996, pp. 49, 56). However, specimens from the Late Roman period are also known (e.g. Khrustal'noe, 
grave VIII, Bujack 1889, p. 277; Jankuhn, archive; Schmiedehelm VM 9.21).

An iron sickle (cat. IV/5/3) came from horse grave No 3a. Sickles appeared in Dollkeim-Kovrovo culture graves already in phase B2a (e.g. Gerojskoe, Zelenogradsk district/ Eisliethen, Kr. Fischhausen, site II, grave 3 (ChilińskaFrüboes 2020, p. 76, Plate 159.9). However, they were not very popular in the Early Roman period. They only became common in the Late Roman period ${ }^{30}$, and were also in use in the Early Migration period ${ }^{31}$. A plane (cat. IV/5/4) was also found in the same grave. Planes were widespread in men's graves in the area of the Dollkeim-Kovrovo culture from the Early Roman period (e.g. Kovrovo, grave 15, see Chilińska-Früboes 2020, p. 64, Plate 109.29; Povarovka, site I, graves I-IV and VII, see Chilińska-Früboes 2020, pp. 99, 101, Plates 239.18, 251.13). However, they became popular in the Late Roman period and also occurred in the Early Migration period (e.g. Gerojskoe, site I, grave 43, Prassolow 2018, p. $243^{32}$, with further literature).

A spindle whorl from phases $\mathrm{C} 1 \mathrm{a}-\mathrm{b}$ was found in grave 4 (cat. IV/6/12). It was lying in an urn probably containing a woman's bones. Other tools came from the same grave, but from a different part of the pit, from a layer of burnt earth: a fire-flint (cat. IV/6/32), a fire-steel (cat. IV/6/33) and an iron spoon (cat. IV/6/36). They were discovered among weapons, which suggests that they came from a man's burial. Fire-making tools were widespread in the area of Dollkeim-Kovrovo culture throughout the Roman period, and are considered to be part of the furnishings of men's graves, while 'spoons' were most likely devices used to maintain ear hygiene. Spoons were found mainly in graves dating from the Late Roman period ${ }^{33}$. Perhaps, however, they also appeared in objects from the Early Roman period (Povarovka, site I, grave I-IV, see ChilińskaFrüboes 2020, p. 99).

Engel defined an artefact from grave 7 (cat. IV/10/5) as a whetstone (Engel 1930a; 1930b; 1930c; SMB-PK/MVF, PM-IXd8, PM-A 1186/1, p. 25), and Schmiedehelm as a rectangular fire flint (Schmiedehelm, archive 7.25.47.182). It is difficult to determine which researcher was right. Perhaps a fragment of an iron object (cat. IV/10/6) was also

${ }^{30}$ For example, Khrustal'noe, grave XXVIIII (Bujack 1889, p. 279; Jakobson, archive Wiekau; Jankuhn, archive), Okunevo, site S, grave 108 (Bujack 1888, pp. 246-247; Jankuhn, archive; Schmiedehelm, archive VM 9.21), formerly Rogehnen, graves 15 and 33 (Jankuhn, archive).

${ }^{31}$ For example, Kovrovo, grave 163 (Tischler and Kemke 1902, p. 24; Schmiedehelm, archive VM 9.21).

${ }^{32}$ In this article, the site number is defined not as I, but as 5 .

${ }^{33}$ For example, Okunevo, site S, grave 108 (Bujack 1888, pp. 246-247; Jankuhn, archive; Schmiedehelm, archive VM 9.21), Putilovo, grave 204 (Chilińska-Früboes 2020, p. 51; Jakobson, archive Corjeiten 006; Jankuhn, archive, Schmiedehelm, archive VM 9.21), maybe also Okunevo, site S, grave 126 (Bujack 1888, p. 248; Schmiedehelm, archive VM 9.21). found in the same grave. It might have been a fire-steel, but we cannot rule out a different interpretation. Moreover, a needle from phases $\mathrm{B} 2-\mathrm{B} 2 / \mathrm{C} 1-\mathrm{C} 1 \mathrm{a}$ was found in grave 5 (cat. IV/7/4).

\section{Other metal objects}

Two handles from phases Cla-b were found in a layer of burnt earth among weapons and tools in grave 4 (cat. IV/6/37-38). Neither their dimensions nor a detailed description of them are known, and only a pencil sketch has survived (Fig. 9.4). They are probably not shield-grips, as Engel would describe these grave goods. They may be the handles of wooden caskets, or perhaps parts of a belt.

An iron bridle (cat. IV/5/5) was discovered in horse grave 3a. In grave 7, an iron bit with bronze parts (cat. IV/10/12) was found in the horse's mouth, perhaps a bit with bronze ferrules that attached the bridle to the bit, but in the absence of documentation, it cannot be stated with certainty. In the same grave, a decorated bronze plate was lying on the horse's skull (cat. IV/10/15), which should be identified as a brow band (Nasenberge). Two bronze fittings (cat. IV/10/11) were found near it: perhaps they were harness decorations.

One coin (cat. VI/1/14) was also discovered at Perdollen. It came from grave $\mathrm{L}$, from phase $\mathrm{B} 2 / \mathrm{C} 1-\mathrm{C} 1 \mathrm{a}$. On the basis of the information provided by Schmiedehelm (archive 7.25.51.121), it is possible to determine that it was an Antoninus Pius sestertius, RIC 623. Coins of the Antonine dynasty flowed into the area of the West Balt cultural circle in great numbers, up to the $260 \mathrm{~s} \mathrm{AD}$, which has already been mentioned in literature many times (Zapolska 2014, p. 80, with further literature). Unfortunately, the discovery from Perdollen is nothing special, and Antoninus Pius coins were also found in Dollkeim-Kovrovo culture cemeteries near Perdollen, e.g. in former Löbertshof, Kr. Labiau (no contemporary name), grave 3 (Bolin 1926, p. 226), and at Davydovka, Polessk district/Poßritten, Kr. Labiau (Schmiedehelm, archive 7.25.51.127; VM 9.21).

Moreover, many fragments of unidentified metal objects were discovered in the cemetery. Four such items came from grave 1 (cat. IV/1/5-8); a large unidentified flat object (cat. IV/4/5) was discovered in grave 3'; two more items in grave 4 (cat. IV/6/28-29); and another two (cat. IV/10/13-14) in grave 7. In grave L, a fragment of an undefined iron object with remnants of earth was found (cat. VI/1/16). Among the stray finds made after Engel's excavations, a button with work through the head (cat. VII/5) was discovered. It should be assumed that it comes from modern times.

Vessels

Vessels or pieces of vessels were found in most graves in Perdollen cemetery. Unfortunately, they are usually 
known only from brief mentions, and only in exceptional cases have detailed descriptions or drawings survived. In grave 5, a cup of type Wiekau decorated with circumference furrows was discovered (cat. IV/7/1; Fig. 9.6). Vessels of this form were typical of Dollkeim-Kovrovo culture in phase B2 (Nowakowski 1996, pp. 59-60), and were also present in phase B2/C1-C1a (Nowakowski 2007, pp. 263264).

A bucket-shaped urn, called an Eimerurne, was discovered in grave 4 , from phases C1a-b (cat. IV/6/1). Vessels of this type appeared in the area discussed in phase B2/ C1 to C1a (Nowakowski 1996, pp. 60, 161-162, map 11), and were still present in the early part of the Migration period. Moreover, a vessel of Dollkeim type (cat. IV/6/2; Fig. 9.3) was inserted into the urn. Such vessels appeared in Dollkeim-Kovrovo culture mainly in the Late Roman period (Nowakowski 1996, p. 60). Inserting smaller vessels (mainly Dollkeim type) into large urns (mainly Eimerurnen) occurred in the Late Roman period in the area of Dollkeim-Kovrovo culture ${ }^{34}$. In addition, there was a third vessel in grave 4 , which was small and had a reddish surface (cat. IV/6/13). Since there is no information that it contained bones, it was not an urn.

The other vessels discovered at Perdollen are known only from brief references. At site I (Heerstraße), small vessels of different colours (cat. I/1/1), probably from modern times, were discovered. Numerous fragments of vessels, some of them very delicate, were found in the flat cemetery (site II) in 1929, i.e. before Engel's excavations (cat. III/1/1, III/2/1, III/3/1). The investigations conducted by Engel in the cemetery in question include: from grave 3, thick pottery fragments; from grave 3' (probably from phase D), a badly destroyed small vessel (cat. IV/4/10), a vessel on a foot (cat. IV/4/11), and fragments of pottery (cat. IV/4/12); from grave 7, some sherds of pottery, maybe fragments of an urn (cat. IV/10/1). In grave 13, which probably contained an urn burial in a stone chest, several vessels from one chronological period (cat. V/2/1) were discovered. Fragments of a vessel also came from grave $\mathrm{L}$ (cat. VI/1/1). Many vessels and pieces of them were also discovered after Engel's excavations and are stray finds, they had different colours and surfaces (cat. VII/1-3).

\section{Chronology}

Site II should be interpreted as a flat cemetery of Dollkeim-Kovrovo culture. Engel dated it to phases B, C, and early phase D (Engel, archive). Undoubtedly, the site was already in use in phase $\mathrm{B} 2 \mathrm{a}$, and grave 12 is the earliest dated object. Graves 15 and C probably come from the Early Roman period, but they cannot be assigned to the

${ }^{34}$ For example, Bol'shoe Isakovo, Gur'evsk district/Lauth, Kr. Königsberg, grave 152 (Skvortsov 2003, pp. 20-21, Figs. 7278), formerly Tengen, grave 25 (Berendt 1873, p. 14, Plate I.ab). earlier or later phase of this chronological period. Several graves can only be roughly dated, to phases B2 - B2/C1C1a (graves: $1,5,7$, stray find cat. II/1/1). Grave L and several stray finds (cat. II/2/1, II/3/1, V/15/1) come from phase B2/C1-C1a. Grave 4 comes from phases C1a-b, and grave $5^{\prime}$ is most likely dated to phase $\mathrm{C} 2$, while grave 3 ' should probably be associated with phase D. The chronology of the remaining objects has not been determined. It should be assumed that the cemetery at Perdollen was in use from phase B2a, most likely up to phase D. Then skeleton burials were dug here in modern times (graves J and K). Similar burials were discovered at site I (Heerstraße). Maybe there was only one modern cemetery at Perdollen with inhumation burials, but it spread in the gravel pit and in Heerstraße. Some modern graves ( $\mathrm{J}$ and $\mathrm{K}$ ) were found in the gravel pit, between graves of Dollkeim-Kovrovo culture and others nearby on Heerstraße.

Funeral rites

The Dollkeim-Kovrovo culture cemetery at Perdollen was badly damaged, partly by ploughing, and partly by excavating sand and gravel. It probably originally had many more graves than were excavated by Engel, and some of them have been destroyed. Moreover, the site has not been fully investigated, which has been emphasised many times.

The study of the funeral rite in the eastern zone of Dollkeim-Kovrovo culture, where the cemetery at Perdollen was located, definitely requires research. The sites located in this region differ slightly in the form of the graves from those known from the central and western part of the Samland Peninsula. For example, there are more barrows and stone circles. The Perdollen cemetery was bi-ritual, six to eight inhumation graves of Dollkeim-Kovrovo culture (graves 1?, 3?, 5, 6, 7, 12, 16, L) were discovered there. According to Engel, the inhumation graves were located on a north-south axis, with the heads directed towards the north, and the deceased lying on their backs (Engel 1930e). The burial pits were oval or rectangular. In three cases (graves 7, 12 and L), the skeletons were lying in wooden coffins (cat. IV/10/9, VI/1/18). In two graves (5 and 7 ), horses were also buried with the skeletons. Moreover, in grave 7, apart from an inhumation burial and a horse burial, an urn burial was probably also discovered. There were burnt human bones and sherds of pottery under the upper layer of the pavement covering the burial pit, which could have been the remains of an urn.

Urns were also discovered in graves 15 and E, and possibly also in grave 13. Grave 4 also contained an urn burial, and well as that probably also a horse burial and a pit burial. Urn graves were probably also discovered in the cemetery before it was investigated by Engel (cat. III/1, III/2, III/3). There are also three grave pits known at the site (graves 3', 5' and C). 
Grave 3a contained a horse burial, but it could have been associated with a human grave (3, 3' or 5$)$. This inaccuracy results from the state of the excavation documentation, and the fact that the site was badly damaged. Moreover, as has already been written, horses were buried in a few other graves (graves $3 \mathrm{a}, 4,5,7$ ). In many cases, information about the type of burial has not survived (graves 2, 10, A, B, D, F, G, H, I).

Almost all the graves contained some kind of stone structure. In most cases, the burial pits were covered with a stone pavement, sometimes with multiple layers, or only with single stones. This applies to both inhumation and cremation graves $(1,2,3,3,4,5,5,6,7,10, \mathrm{~B}, \mathrm{D}, \mathrm{F}, \mathrm{H}$, I). Grave 7 contained human and horse burials, covered with a four-layer stone pavement, surrounded by a stone circle (Fig. 11). Graves 15 and E, containing urn burials, were also surrounded by stone circles, as was grave 16 with an inhumation burial. In a few cases, the burials (urn and grave pit) were in stone chests (graves 13, C, G). In one case (grave G), the stone chest was additionally surrounded by a rectangular stone construction.

The presence of stone pavements over the burial pits, or only single stones in the pit ceiling, is typical of DollkeimKovrovo culture (Hollack 1908, pp. 172-174; Okulicz 1973, p. 367; Chilińska 2009, pp. 151-152, with further literature). According to Engel, the presence of stone circles around graves from the Roman period in Perdollen cemetery refers to an older Earliest Iron Age tradition, and this seems to be a justified observation. However, these constructions find numerous analogies in other cemeteries of Dollkeim-Kovrovo culture (Engel 1935, p. 93). Also, the presence of stone chests in burials from the Roman period undoubtedly refers to the tradition of West Balt Barrow culture.

Burying horses in human burials is nothing unusual for Dollkeim-Kovrovo culture (e.g. Hollack 1908, pp. 180-181; Jankuhn 1933, p. 204; Engel 1935, pp. 68-69). However, these graves are almost always related to a male burial. It is noteworthy that grave 4 , where a horse was probably buried, was probably a female burial. However, a lot of weapons and tools were found in the same grave, lying in a layer of burnt earth, so it cannot be ruled out that this grave also contained a destroyed warrior's grave pit. There are known cases of other graves of DollkeimKovrovo culture from the Late Roman period in which a woman was buried in addition to a warrior and a horse (Engel 1935, p. 69), but these are isolated cases. Usually, only a warrior was buried in a grave next to a horse or over a horse.

\section{Conclusions}

Working with the Perdollen material is like trying to put together a puzzle that has fallen apart and many pieces have been lost. It is an extremely interesting cemetery, due to the history of its research. Almost a hundred years ago, archaeologists, and the local community devoted time to this cemetery. Reports of the discoveries reached the local press, the authorities, and even the gendarmes (!), but then they were forgotten and never published. This article is an attempt to introduce these missing materials into the literature. It is hampered by incomplete field documentation, often damaged, and sometimes written in pencil so blurred that it is no longer legible. The analysis of the material is also hindered by the fact that all the grave goods (except for one fibula) have been lost, and are known only from brief mentions. Secondly, we know very little about the Dollkeim-Kovrovo culture material from this region. Gaerte mentioned this in letters to the local community, and in fact, little has changed since then. The region should be analysed, also in terms of the funeral rite, which is a little different from the one seen in the big cemeteries of Dollkeim-Kovrovo culture in the western and central part of the Samland Peninsula.

\section{Acknowledgements}

I would like to thank Prof. Claus von Carnap-Bornheim and Volker Hilberg, PhD (Museum für Archäologie, Stiftung Schleswig Holsteinische Landesmuseen Schloss Gottorf, Schleswig), Immo Heske, PhD (GeorgAugust-Universität Göttingen, Göttingen), Horst Junker and Heino Neumayer, PhD (Museum für Vor- und Frühgeschichte, Staatliche Museen zu Berlin, Preußischer Kulturbesitz, Berlin), Ülle Tamla and Mirja Ots, PhD (Tallinna Ülikooli Arheoloogiline Teaduskogu, Arhiiv, Tallin), Peter Wörster, $\mathrm{PhD}$ and Dorothee Goeze (Johann Gottfried Herder-Institut für historische OstmitteleuropaForschung - Institut der Leibniz-Gemeinschaft, Marburg) for permission to publishing information from archives.

\section{Abbreviations}

Archaeol. Baltica - Archaeologia Baltica

Sb Prussia - Sitzungsberichte der Alterthumsgesellschaft Prussia zu Königsberg i. Pr.

WA - Wiadomości Archeologiczne 


\section{References}

\section{Manuscripts and archival records}

CAEG. Archive of Carl Engel - part kept in the Georg-AugustUniversität, Göttingen.

Chilińska, A., 2009. „Jede Grabung hat noch stets etwas Neues gebracht“. Wczesnorzymskie materiały pochodzące z cmentarzyska kultury Dollkeim-Kovrovo w Corjeiten/Putilovo na Sambii. Thesis (master's), University of Warsaw.

DSHI 100 La Baume 9. Archive of Herbert Jankuhn - notes kept among Wolfgang La Baume's notes in the Herder-Institut für historische Ostmitteleuropaforschung, Marburg.

DSHI 100 Engel. Archive of Carl Engel, part kept in the HerderInstitut für historische Ostmitteleuropaforschung, Marburg (signature DSHI 100 Engel).

Engel, archive. Archive of Carl Engel - part kept in the Museum für Archäologie, Schleswig.

Grenz, archive. Archive of Rudolf Grenz kept in the Museum für Archäologie, Schleswig.

Jakobson, archive. Archive of Feliks Jakobson kept in the Latvijas Vēstures muzejs, Riga, published in: Archeologiczne dziedzictwo Prus Wschodnich w archiwum Feliksa Jakobsona / Das archäologische Vermächtnis Ostpreußens im Archiv des Felix Jakobson / Austrumprūsijas arheoloğiskais mantojums Fëliksa Jākobsona arhī $\bar{a}$, T. Nowakiewicz, ed. Aestiorum Hereditas 2, Warszawa 2011.

Jankuhn, archive. Archive of Herbert Jankuhn - part kept in the Museum für Archäologie, Schleswig.

Schmiedehelm, archive. Archive of Marta Schmiedehelm kept in the Tallinna Ülikooli Arheoloogiline Teaduskogu, Tallinn.

Schmiedehelm, archive VM 9.21. Archive of the former Archäologische Kabinett der Universität Tartu - part prepared by Marta Schmiedehelm, kept in the Tallinna Ülikooli Arheoloogiline Teaduskogu, Tallinn.

Skvortsov, K.N., (Skvorzov, K.N.) 2003. Otchet po okhrannym raskopkam gruntovogo mogil'nika Laut - Bol'shoe Isakovo Sambijskogo-Natangijskoj arkheologicheskoj ekspeditsej v 2002 godu unprinted excavation report in the Institute of Archaeology Russian Academy of Science, No. 25795.

SMB-PK/MVF, PM-IXb, PM-F. Part of the Prussia Museum's archive - photo collection, kept in the Museum für Vor- und Frühgeschichte, Staatliche Museen zu Berlin, Preußischer Kulturbesitz, Berlin.

SMB-PK/MVF, PM-IXd8, PM-A. Part of the Prussia Museum's archive kept in the Museum für Vor- und Frühgeschichte, Staatliche Museen zu Berlin, Preußischer Kulturbesitz, Berlin.

Teaching Collection of the former Archäologische Kabinett der Universität Tartu kept in the Tallinna Ülikooli Arheoloogiline Teaduskogu, Tallinn.

\section{Literature}

Almgren, O., 1897. Studien über Nordeuropäische Fibelformen der ersten nachchristlichen Jahrhunderte mit Berücksichtigung der provinzialrömischen und südrussischen Formen. Stockholm: Haeggström.

Andrzejowski, J., Cieśliński, A., 2007. Germanie i Bałtowie u schyłku starożytności. Przyjazne związki czy wrogie sąsiedztwo? In: A. Bitner-Wróblewska, ed. Kultura bogaczewska w 20 lat później. Materiały z konferencji, Warszawa, 26-27 marca 2003, Seminarium Bałtyjskie, vol 1. Warszawa: Janusz Bieszczad, pp. 279-319.
Åberg, N., 1919. Ostpreussen in der Völkerwanderungszeit. Uppsala-Leipzig: A.-B. Akademiska Bokhandeln and Otto Harrassowitz.

Beckmann, Ch., 1969. Metallfingerringe der römischen Kaiserzeit im freien Germanien. Saalburg-Jahrbuch, XXVI, 5-106.

Berendt, G., 1873. Zwei Gräberfelder in Natangen. Schriften der Königlichen Physikalisch-ökonomischen Gesellschaft zu Königsberg i. Pr., 14, 1-23.

Bezzenberger, A., 1909. Gräberfeld verschiedener Perioden bei Schuditten, Kr. Fischhausen. Sb Prussia, 22 (1900-04), 44-63.

Bolin, S., 1926. Die Funde römischer und byzantinischer Münzen in Ostpreußen. Sb Prussia, 26 (1922/23-1925), 203-240.

Bujack, G., 1888. Die Accession des Prussia-Museums pro 1887. Sb Prussia, 13 (1886/87), 195-272.

Bujack, G., 1889. Accessionen des Prussia-Museums pro 1888. Sb Prussia (1887/88), 14, 260-299.

Chilińska-Drapella, A., 2010. Próba nowego spojrzenia na „pasy sambijskie". WA, LXI (2009/10), 3-79.

Chilińska-Früboes, A., 2017. Zapinki oczkowate serii pruskiej z terenu kultury Dollkeim-Kovrovo. WA, LXVIII, 45-106.

Chilińska-Früboes, A., 2020. Fibel, Tracht und Interkulturalität. Die Dollkeim/Kovrovo-Kultur der älteren Römischen Kaiserzeit im nördlichen Ostpreußen. Studien zur Siedlungsgeschichte und Archäologie der Ostseegebiete, 18/1-2. Kiel-Hamburg: Wachholtz.

Chilińska-Früboes, A., Skvorcov, K.N., 2022 (in press). Openwork Roman Disc Brooches and Mounts and their Local Imitations in the Area of the Western Balts, In: M. Olędzki, A. Dubicki eds. Rome and the Barbarians. Mutual relations of the two Worlds. Łódź.

Engel, C., 1930a. Zweitausendjähriges Gräberfeld. Roß und Reiter nebeneinander bestattet. Königsberger Hartungschen Zeitung, 258 (04.06.1930).

Engel, C., 1930b. Roß und Reiter vor 2000 Jahren. Zweittausendjähriges Gräberfeld bei Perdollen (Kreis Labiau). Königsberger Allgemeine Zeitung, 258 (04.06.1930).

Engel, C., 1930c. Neues zur Gotenfrage in Ostpreußen. Die 2000 jährigen Skelettgräber bei Perdollen, Kr. Labiau. Unsere Heimat, 31/12 (15.08.1930), 290.

Engel, C., 1930d. Neu Ausgrabungen bei Perdollen. 2000 jährige Skelettgräber und Steinkisten. Königsberger Hartungschen Zeitung, 337 (22.07.1930).

Engel, C., 1930e. Skelettgräber Steinkisten und Pestgräber. Neue Ausgrabungen im Kreise Labiau. Königsberger Allgemeine Zeitung, 339 (23.07.1930).

Engel, C., 1931. Tätigkeitsbericht der vorgeschichtlichen Abteilung des Prussia-Museums in Königsberg i Pr. Nachrichtenblatt für deutsche Vorzeit, VII/1, 6-11.

Engel, C., 1935. Vorgeschichte der altpreußischen Stämme. Untersuchungen über Siedlungsstetigkeit und Kulturgruppen im vorgeschichtlichen Ostpreußen, I. Königsberg: Gräfe u. Unzer.

Engel, C., La Baume, W., 1937. Kulturen und Völker der Frühzeit im Preußenlande, Atlas der Ost- und Westpreußischen Landesgeschichte I. Teil. Königsberg: Gräfe u. Unzer.

Ettlinger, E., 1973. Die römischen Fibeln in der Schweiz. Handbuch der Schweiz zur Römer- und Merowingerzeit, Bern: Francke.

Feugère, M., 1985. Les Fibules en Gaule Méridionale de la conquête à la fin du Ve s. ap. J.-C. Paris. Revue archéologique de Narbonnaise, 12.

Gaerte, W., 1927. Vorgeschichtliche Ausgrabungen, Funde und Feststellungen in Ostpreußen während der Jahre 1925-26. Nachrichtenblatt für deutsche Vorzeit, III/1, 9-11.

Gaerte, W., 1929. Urgeschichte Ostpreußens. Königsberg: Gräfe u. Unzer. 
Garbsch, J., 1965. Die norisch-pannonische Frauentracht im 1. und 2. Jahrhundert. In: Münchner Beiträge zur Vor- und Frühgeschichte, 11. München: Beck.

Hollack, E., 1908, Die Grabformen ostpreussischer Gräberfelder. Zeitschrift für Ethnologie, 40, 145-193.

Ibsen, T., Skvorzov, K.N. (Skvortsov), 2005. Das Gräberfeld von Berezovka/Groß Ottenhagen. Ein wiederentdeckter Bestattungsplatz des 1. Jahrtausends n. Chr. im Kaliningrader Gebiet. Bericht der Römisch-Germanischen Kommission, 85 (2004), $379-452$.

Jankuhn, H., 1933. Zur Besiedlung des Samlandes in der älteren römischen Kaiserzeit. Sitzungsberichte der Alterthumsgesellschaft Prussia, 30, 202-226.

Khomiakova, O., 2015. Disc Brooches of Dollkeim-Kovrovo Culture. The Question of the Origin of Ornaments in the Southeast Baltic in the First Centuries AD. Archaeol. Baltica, 21-22, 14-39.

Khomiakova, O., 2016. The landscape and spatial analysis of Roman Period archaeological sites at the eastern border of Dollkeim-Kovrovo/Sambian-Natangian Culture. Archaeol. Baltica, 23, 58-80.

Khomiakova, O.A., 2017. Fibuly-Broshi v Kulturakh Vostochnoj Baltii. In: V.E. Rodinkova, O.S. Rumiantseva, ed. Evropa ot Latena do Srednevekov'ia: varvarskij mir i rozhdenie slavianskikh kul'tur k 60-letiiu A.M. Oblomskogo. Ranneslavianskij mir, 19, pp. 149-160.

Kontny, B., 2016. Siekiery tulejkowe z kultur bogaczewskiej i sudowskiej. WA, LXVII, 37-64.

Klebs, R., 1877. Bericht über die neuen Ausgrabungen in Tengen bei Brandenburg (Natangen), ausgeführt im Sommer 1875. Schriften der Königlichen Physikalisch-ökonomischen Gesellschaft zu Königsberg i. Pr., 17, 51-62.

Lund Hansen, U. and Przybyła, M., 2010. Rosettenfibeln - ein Klassifikationsversuch, In: U. Lund Hansen, A. BitnerWróblewska, eds. Worlds apart? Contacts across the Baltic Sea in the Iron Age. Network Denmark-Poland 2005-2008. Nordiske Fortidsminder C/7. København-Warszawa: Det Kongelige Nordiske Oldkriftselskab and Państwowe Muzeum Archeologiczne, pp. 241-286.

Madyda-Legutko, R., 1987. Die gürtelschnallen der römischen kaiserzeit und der frühen völkerwanderungszeit im mitteleuropäischen barbaricum. In: BAR British Archaeological Reports. International Series, 360. Oxford.

Madyda-Legutko, R., 2011. Studia nad zróżnicowaniem metalowych części pasów w kulturze przeworskiej. Okucia końca pasa. Kraków: Historia Iagiellonica.

Mattingly, H., Sydenham, E., 1930. Roman Imperial Coinage, vol. III: Antoninus Pius to Commodus. London: Spink.

Moora, H., 1938. Die Eisenzeit in Lettland bis etwa 500 n.Chr. II. Analyse. Verhandlungen der Gelehrten Estnischen Gesellschaft, 29. Tartu: J. G. Krüger.

Nowakowski, W., 1994. Kultura przeworska a zachodniobałtyjski krąg kulturowy, In: J. Gurba, A. Kokowski, eds. Kultura przeworska, I. Lublin, pp. 373-388.

Nowakowski, W., 1995. Od Galindai do Galinditae. Z badań nad pradziejami bałtyjskiego ludu z Pojezierza Mazurskiego. Barbaricum, 4. Warszawa.

Nowakowski, W., 1996. Das Samland in der römischen Kaiserzeit und seine Verbindungen mit dem römischen Reich und der barbarischen Welt. Veröffentlichung des Vorgeschichtlichen Seminars Marburg, 10. Marburg-Warszawa.

Nowakowski, W., 1998. Die Funde der römischen Kaiserzeit und der Völkerwanderungszeit aus Masuren. Museum für Vor- und Frühgeschichte. Staatliche Museen zu Berlin. Bestandskataloge, 6. Berlin.
Nowakowski, W., 2001. Żelazne zapinki kuszowate z podwiniętą nóżką w europejskim Barbaricum. WA, LIV (1995-1998), 129-146.

Nowakowski, W., 2007. Po obu stronach Pasłęki - puchary grupy VIII na Sambii, In: M. Fudziński, H. Paner, eds. Nowe materiały i interpretacje. Stan dyskusji na temat kultury wielbarskiej. Gdańsk, pp. 259- 271.

Nowakowski, W., 2013. Masuren in der römischen Kaiserzeit. Auswertung der Archivalien aus dem Nachlass von Herbert Jankuhn. Studien zur Siedlungsgeschichte und Archäologie der Ostseegebiete, 12. Neumünster: Wachholtz.

Okulicz, J., 1973. Pradzieje ziem pruskich od późnego paleolitu do VII w. n.e. Monografie Dziejów Społecznych i Politycznych Warmii i Mazur, I. Wrocław-Warszawa-Kraków-Gdańsk: Ossolineum.

Prassolow, J.A., 2018. Die völkerwanderungszeitlichen Dolchmesser der samländisch-natangischen Kultur auf dem Gebiet des ehemaligen Ostpreussens. Studien zur Siedlungsgeschichte und Archäologie der Ostseegebiete, 15. Mainz: Wachholtz.

Raddatz, K., 1992/1993. Der Wolka-See, ein Opferplatz der römischen Kaiserzeit in Ostpreußen. Offa, 49/50, 127-187.

Riha, E., 1979. Forschungen in Augst, 3. Augst: Amt für Museen und Archäologie des Kantons Basel-Landschaft.

Schmiedehelm, M., 2011. Das Gräberfeld am Jaskowska-See in Masuren. Studien zur westmasurischen Kultur der römischen Eisenzeit. Warszawa: Instytut Archeologii Uniwersytetu Warszawskiego.

Skvortsov, K.N. (Skvorzov), 2012a. Novye nakhodki pamiatnikov rimskogo vremeni na roberezhe Vislinskogo zaliva. Ot Rimskogo Limesa do Velikoj Kitajskoj Steny, From Roman Limes to the Great Chinese Wall. Stratum plus, 4, 1-18.

Skvortsov, K.N. (Skvorzov), 2012b. The Formation of a SambianNatangian Culture Patrimonial Elite in the Roman Period in the Context of the Amber Trade. Archaeol. Baltica, 18, 167191.

Szter, I., 2010. Cmentarzysko z okresu wpływów rzymskich i z okresu wędrówek ludów w Kamieniu na Pojezierzu Mazurskim. WA, XLI (2009/10), 201-331.

Szymański, P., 2006. Dwie zapinki z dawnego Rothebude i z Czerwonego Dworu. Kontakty tzw. skupienia gołdapskiego kultury sudowskiej, In: W. Nowakowski, A. Szela, eds. Pogranicze trzech światów. Kontakty kultur przeworskiej, wielbarskiej $i$ bogaczewskiej $w$ świetle materiałów $z$ badań i poszukiwań archeologicznych. Światowit Supplement Series P: Prehistory and Middle Ages XIV. Warszawa, pp. 369-380.

Tempelmann-Mączyńska, M., 1985. Die Perlen der römischen Kaiserzeit und der frühen Phase der Völkerwanderungszeit im mitteleuropäischen Barbaricum. In: Römisch-Germanische Forschungen, 43. Mainz.

Tischler, O., Kemke, H., 1902. Ostpreussische Altertümer aus der Zeit der grossen Gräberfelder nach Christi Geburt. Königsberg: Kommission bei Wilh. Koch.

Woźniak, M., 2013. An iron bell-shaped pendant from the cemetery of the Wielbark Culture in Kozłówko in northern Masovia. Archaeologia Lituana, 14, 51-62.

Zapolska, A., 2014. Monety rzymskie z cmentarzyska płaskiego w Łężanach, In: A. Wiśniewska, ed. Łężany. Cmentarzysko z okresu wpływów rzymskich i wędrówek ludów na Pojezierzu Mrągowskim. Badania w sezonie 2013 / Łężany. Cemetery of the Roman Period and the Migration Period in the Mrągowo Lake District. Research in season 2013. Warszawa, pp. 70-101. 


\section{IEŠKANT PRARAST Ų DËLIONĖS \\ ELEMENTŲ: DOLLKEIMO- KOVROVO KULTŪROS KAPINYNAS PERDOLLEN VIETOVËJE}

\section{AGATA CHILIŃSKA-FRÜBOES}

\section{Santrauka}

Buvusioje Perdollen vietoveje (1.1 pav.) buvo rastas Dollkeimo-Kovrovo kultūros kapinynas (paminklas II), taip pat naujujų laikų kapinynas su griautiniais kapais (paminklas I). Plokštinis kapinynas buvo iš dalies išsidèstęs žvyrduobès areale, iš dalies - ariamajame lauke (1.2-3, 3.1 pav.). Jis buvo pažeistas arimo ir žvyro bei smèlio kasybos.

Kapinynas buvo tyrinètas Carlo Engelio ir kitų muziejaus „Prussia“ darbuotojų XX a. 4-ajame dešimtmetyje (3.2 pav.). Be kita ko, jis nebuvo iki galo ištirtas, ir pranešimų apie radinius iš šio kapinyno žinoma ir vèlesniais laikais, kai kasinejjimai buvo baigti. Archeologiniai tyrinejimai Perdollen vietoveje publikacijose minimi gana retai ir dažniausiai yra mokslo populiarinimo pobūdžio. Archyvinè medžiaga suteikia neịkainojamą žinių papildymą. MVF saugoma didelẻ byla, kurioje esama muziejaus „Prussia“ archyvinès medžiagos, susijusios su tyrinèjimais šiame kaime (SMB-PK/MVF, PM-IXd8, PM-A 1186/1). 65 puslapių dokumentikoje tarp kitų fragmentų yra prastos būklès Engelio kasinèjimų dienoraštis (2 pav.). Ypač daug informacijos apie tyrinejimus Perdollen taip pat suteikè Rudolfo Grenzo palikimas (archyvas, 86 knyga). Šiame archyve, be kitos medžiagos, išliko straipsnių ir publikuotų nuorodų, kurias transkribavo Grenzas, bet dar svarbesnès yra fotografijos $(3-4 ; 6 ; 11.1 ; 12,1.4 ; 13-16$ pav.), kurias padarè Engelis kasinejjimų Perdollen metu. Jos Engelio aprašytos antrose pusėse, nors, deja, dažniausiai nenurodant kapo numerio. Taip pat ir kituose asmeniniuose archyvuose yra saugomi duomenys apie medžiagą iš Perdollen.

Paminklas II vertintinas kaip plokštinis Dollkeimo-Kovrovo kultūros kapinynas. Engelis jị datavo fazèmis B, C ir ankstyvuoju fazès D tarpsniu (Engel, archyvas). Neabejotina, kad laidojimo paminklas buvo naudojamas jau B2a fazejje, o kapas 12 yra ankstyviausiai datuojamas objektas. Kapai 15 ir C greičiausiai susiję su ankstyvuoju romėniškuoju laikotarpiu, bet jų neįmanoma priskirti ankstyvesnei arba vèlyvesnei šio chronologinio laikotarpio fazei. Keletą kapų galima datuoti labai apytikriai - B2-B2/C1C1a laikotarpiu (kapai: 1, 5, 7, atsitiktinis radinys kataloge II/1/1). Kapas L ir keletas atsitiktinių radinių (kataloge $\mathrm{II} / 2 / 1, \mathrm{II} / 3 / 1, \mathrm{~V} / 15 / 1$ ) yra kilę iš B2/C1-C1a fazès. Kapas 4 priklauso fazėms $\mathrm{Cla}-\mathrm{b}$, o kapas 5 ' greičiausiai datuotinas faze C2. Tuo tarpu kapas 3' turbūt susijęs su faze D. Kitų objektų chronologija nebuvo nustatyta. Apibendrinant reikia pasakyti, kad Perdollen kapinynas buvo naudojamas nuo fazès B2a, tikètina, iki fazès D. Vèliau, naujaisiais laikais, buvo įkasti griautiniai palaidojimai (kapai J ir K). Panašių kapų buvo rasta laidojimo paminkle I (Heerstraße gatvejje). Galbūt Perdollen vietoveje buvo tik vienas naujụjų laikų kapinynas su griautiniais kapais, kuris driekèsi žvyrduobès ir Heerstraße areale. Kai kurie vèlyvieji kapai (J ir K) buvo rasti žvyrduobeje, ịsiterpę tarp DollkeimoKovrovo kultūros kapų, o kiti - netoliese Heerstraße.

Dollkeimo-Kovrovo kultūros rytinès zonos, kurioje esama Perdollen kapinyno, laidosenos studijos neabejotinai reikalauja tolesnių tyrimų. Laidojimo paminklai, išsidèstę šiame regione, šiek tiek skiriasi kapų forma nuo tų palaidojimų, kurie žinomi centrinèje ir vakarinejje Sembos pusiasalio dalyje - pavyzdžiui, esama daugiau pilkapių ir akmenų vainikų. Perdollen kapinynas buvo biritualus, su 6-8 griautiniais kapais (1?, 3?, 5, 6, 7, 12, 16, L), bent su 2-4 kapais urnose (7?, 13?, 15, E), 3 kapais duobèse (kapais 3', 5', C), 4 žirgų kapais (3a, 4, 5, 7). Nemaža atvejų, kai žinių apie kapų tipus neišliko (kapai 2, 10, A, B, D, F, G, H, I).

Beveik visuose kapuose rasta tam tikrų akmenų struktūrų. Daugeliu atvejų laidojimo duobès buvo padengtos akmenu grindiniu, kartais keliasluoksniu, arba pavieniais akmenimis. Tai pastebèta tiek griautiniuose, tiek degintiniuose kapuose $(1,2,3,3$, 4, 5, 5, 6, 7, 10, B, D, F, H, I). Kape 7 būta žmogaus ir arklio palaidojimų, kurie uždengti keturių sluoksnių akmenų grindiniu, apsuptu akmenų vainiku (11 pav.). Taip pat kapai 15 ir E, kuriuose būta palaidojimų urnose, buvo apsupti akmenų vainikais, kaip ir griautinis kapas 16. Keletu atvejų palaidojimai (urnose ir duobėse) buvo rasti akmenų děžèse (kapai 13, C, G). Vienu atveju (kapas $\mathrm{G}$ ) akmenų dèžè papildomai buvo apsupta keturkampe akmenų konstrukcija. 